Portland State University

PDXScholar

$1-1-2012$

\title{
Voicing Oppositional Conformity: Sarah Winnemucca and the Politics of Rape, Colonialism, and "Citizenship": 1870-1890
}

Jennifer Bailey

Portland State University

Follow this and additional works at: https://pdxscholar.library.pdx.edu/open_access_etds Let us know how access to this document benefits you.

Recommended Citation

Bailey, Jennifer, "Voicing Oppositional Conformity: Sarah Winnemucca and the Politics of Rape, Colonialism, and "Citizenship": 1870-1890" (2012). Dissertations and Theses. Paper 801.

https://doi.org/10.15760/etd.801

This Thesis is brought to you for free and open access. It has been accepted for inclusion in Dissertations and Theses by an authorized administrator of PDXScholar. Please contact us if we can make this document more accessible: pdxscholar@pdx.edu. 


\title{
Voicing Oppositional Conformity:
}

Sarah Winnemucca and the Politics of Rape, Colonialism, and "Citizenship": 1870-1890

by

Jennifer Bailey

A thesis submitted in partial fulfillment of the requirements for the degree of

\author{
Master of Arts \\ in \\ History
}

Thesis Committee:

Patricia A. Schechter, Chair

Linda Walton

Katrine Barber

Ann Marie Fallon

Portland State University

(C)2012 


\begin{abstract}
Sarah Winnemucca, a Paiute Indian born around the year 1844, crossed cultural boundaries and became an influential voice within both white and Indian societies. This thesis employs a settler colonial framework that places the sexuality and rape of native women at the center of colonial relations in the settlement of the Americas. Viewed through this lens I perform an in-depth analysis of Winnemucca's gendered critique of colonialism that focused on sexual violence. Rather than the unstable, mixed messages of native resistance and assimilation emphasized by earlier scholars, I argue that Winnemucca purposefully employed a strategy of oppositional conformity to publicize an unwavering political message that championed Paiute sovereignty, exposed white cruelty, and re-wrote the dominant gendered, racial, political and cultural constructs that bound Native American women's identity.

The introduction begins with a brief history of Winnemucca's life and accomplishments. In the introduction I also address the authenticity of Winnemucca's published narrative, Life Among the Piutes: Their Wrongs and Claims (1883) and identify the constraints of the settler colonial lens through which I view Winnemucca's public voice. In chapter one I argue that Winnemucca's narrative employs the gendered moral rhetoric of the colonizer to cultivate white audience receptiveness, while simultaneously criticizing whites for their brutality against Indians. In chapter two I assert that
\end{abstract}


Winnemucca employed multiple political strategies to cut away at Euro-American settlers' moral justifications for colonialism, and that she articulated a unique vision of Paiute "citizenship" that rejected complete Indian assimilation. In chapter three I highlight the ways in which Winnemucca used her public voice to articulate rape and the sexuality of Indian women as a foundational part of colonialism hidden from view in the media coverage of the Indian wars of the late nineteenth century. Unlike her biographers, who mostly overlook Winnemucca's public challenge to the negative sexual stereotypes that plagued Indian women during Winnemucca's lifetime, I argue that Indian women's sexuality was a foundational theme in Winnemucca's public discourse. Winnemucca grasped and resisted the gendered dimensions of colonialism and her consistent focus on this theme echoed in her lived reality. Finally, I conclude that ultimately personal accusations as well as her inability to escape the "heathen" identity forced on Indians by Christian reformers thwarted the success of Winnemucca's political message. 
For

\author{
My boys \\ Bridger, Matthew, and Lincoln \\ Who hold my heart in their little hands
}




\section{ACKNOWLEDGMENTS}

Many people deserve to be recognized with this project. My heartfelt thanks and highest regard are due to Dr. Patricia Schechter for getting on board with this project and pushing me past my own perceived academic ability. More importantly, I am indebted to her for patiently teaching me how not what to think about women's history. Indeed, she is a true teacher. Special gratitude goes to my sweetheart for his well-timed humor and unfailing support. More than a simple thank you is due my mom who understood how important this project was to me and stepped in to watch my boys to make this project materialize and to Linda for her refreshing optimism and interest in this project. 
Table of Contents

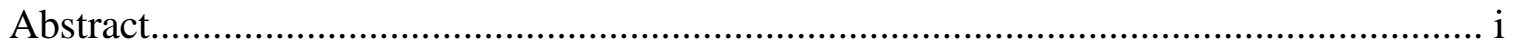

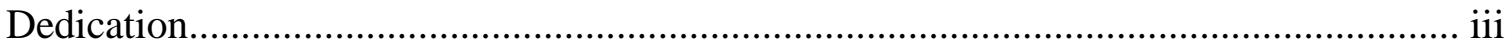

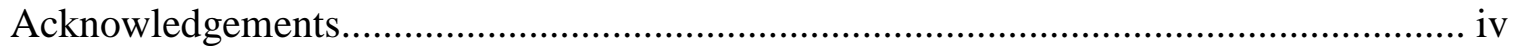

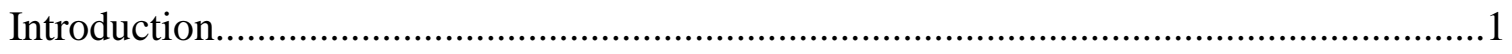

Chapter One

Sarah Winnemucca's Oppositional Conformity.........................................................11

Chapter Two

Opposing Colonialism, Revising Citizenship...........................................................44

Chapter Three

Resisting Gendered Violence: Struggles in the Public Sphere ......................................78

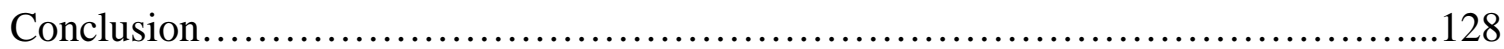

References............................................................... 133 


\section{INTRODUCTION}

Sarah Winnemucca, a Paiute girl born around the year 1844, grew to become an influential leader in both white and Indian societies. Her given Indian name, Thocmetone, meant Shell Flower. When she died the New York Times ran a front page article entitled, "Princess Winnemucca Dead: The Most Remarkable Woman Among the Piutes of Nevada."1 Among her many accomplishments, she reportedly knew five languages, (three Indian languages as well as English and Spanish), served as an interpreter for her people, lectured across the United States for the Indian cause, taught at an Indian school she established, and published the first book written in English by an Indian woman in the United States. ${ }^{2}$

Sarah Winnemucca lived in the rapidly changing world of the nineteenth century west. As white settlers invaded Winnemucca's homeland, the life she and her native people once knew swiftly came under siege. Winnemucca found herself wedged between two incredibly different worlds. From a young age Winnemucca learned the art of adapting and re-adapting to her constantly changing surroundings. In contrast to the handful of scholars who have interpreted Winnemucca and her voice in the last ten years, I place emphasis on Winnemucca's public voice as it intersects with Euro-American colonial race and gender ideologies. Previous writers have emphasized Winnemucca's

\footnotetext{
1 "Princess Winnemucca Dead: The Most Remarkable Woman Among the Piutes of Nevada," New York Times, 27 October, 1891.

${ }^{2}$ Sally Zanjani, Sarah Winnemucca (Lincoln: University of Nebraska Press, 2001), 3.
} 
"remarkable leadership," her "hybrid selves," or her "cultural liminality," an emphasis that obscures what I found most striking about Winnemucca's writings: her focus on women and issues of what modern scholars call "gender."3 It was beyond the scope of this project to do an extensive evaluation of gender in Paiute society; such a study would require a grounding in anthropology and other methodologies and sources. However, recent feminist theory on the history of women and colonialism, namely the "settler colonial theory," allows me to place Winnemucca primarily in the context of her career as an interlocutor with white Americans in the military, government, and social reform circles. ${ }^{4}$

Prominent among interlocutors were white women Protestant reformers. Winnemucca's narrative was edited by Mary Mann, an influential white Bostonian woman; as a result some scholars have dismissed the work as inauthentic. Indeed historian Kathleen Mullen Sands describes the challenges associated with the collaborative process of Indian autobiography. She writes,

The intervention of a mediator...complicates the issues of voice and reliability enormously since the published narrative is actually a bicultural composition...bicultural narrative doesn't simply double the problem of reliability, it multiplies the complexity of the interpretation. The

\footnotetext{
${ }^{3}$ See Zanjani, Sarah Winnemucca, especially chapter fourteen. See also Carolyn Sorisio, "Playing the Indian Princess? Sarah Winnemucca's Newspaper Career and Performance of American Indian Identities," Studies in American Indian Literatures 23, no. 1 (May 14, 2011): 137. See also Cari Carpenter, "Tiresias Speaks: Sarah Winnemucca's Hybrid Selves and Genres," Legacy 19, no. 1 (2002): 71-80.

${ }^{4}$ Margaret Jacobs, "Getting Out of a Rut: Decolonizing Western Women's History," Pacific Historical Review 79, no. 4 (November 2010): 585-604. See also Patrick Wolfe, "Land, Labor, and Difference: Elementary Structures of Race," American Historical Review 106, no. 3 (June 2001): 866-905.
} 
relationship between truth and illusion, story and reality is one not only of intimate codependence but of multiple codependences affected by colonialism. ${ }^{5}$

My question for her narrative is not so much its essential authenticity as to its utility in several contexts, why and how it was effective or less so in achieving Winnemucca's aims. Her editor, Mary Mann, validated the text as follows, "My editing has consisted in copying the original manuscript in correct orthography and punctuation, with occasional emendations by the author...I am confident that no one would desire that her own original words should be altered." ${ }^{, 6}$ Mann also commented in a letter to a friend regarding Winnemucca's manuscript: “...the story is heartbreaking, and told with a simplicity and eloquence that cannot be described." ${ }^{, 7}$ One of Winnemucca's recent biographers, Sally Zanjani, cites anthropologist Catherine Fowler as pointing out that, "pronunciation spellings such as "Acotrass" for "Alcatraz" and "Carochel" for "Churchill" in the published book are surely Sarah's own, unnoticed by Mann." ${ }^{\text {L }}$ Life Among the Piutes is a mediated text but the burden of this thesis addresses the text's importance as a political statement printed for white audiences.

While Winnemucca's narrative was probably self-penned, the likelihood that she wrote the book for political purposes is a central theme in my argument. Native

\footnotetext{
${ }^{5}$ Kathleen Mullen Sands, American Women's Autobiography, ed. Margo Culley (Madison: University of Wisconsin Press, 1992), 271.

${ }^{6}$ Sarah Winnemucca Hopkins, Life Among the Piutes: Their Wrongs and Claims (Reno: University of Nevada Press, 1994), p 2.

${ }^{7}$ Gae Whitney Canfield, Sarah Winnemucca of the Northern Paiutes (Norman: University of Oklahoma Press, 1983), 203.

${ }^{8}$ Zanjani, Sarah Winnemucca, 240.
} 
American literature specialists have debated the use of Winnemucca's narrative as an autobiography and point to its "heavily biased and acculturated and Christianized viewpoint," as proof of its questionable reliability about Paiute life. ${ }^{9}$ Indeed the book's title, Life Among the Piutes: Their Wrongs and Claims, evidences Winnemucca's hopes of gaining redress by publicizing the wrongs done to her people. Mary Mann wrote a letter to a friend confirming that Winnemucca's principle motive for writing the book was to, "influence the public mind by the details of the Indian wrongs...."10 Winnemucca wrote the book in a short three months during the height of her lecture career in the spring of 1883 while staying with Elizabeth Peabody in Boston, MA. Her intention was to sell the book to East Coast audiences after her lectures, and both Peabody and Mann attribute the book's conception as Winnemucca's “own deep impulse originating in her wish to tell the whole story that she could only touch upon in the limited time of a single lecture."11 Indeed, as early as 1881 - a few years after Winnemucca began lecturing - she was considering writing a book as evidenced by a letter she wrote to her friend General Oliver O. Howard on the subject. ${ }^{12}$ The book was also intended to introduce Winnemucca to East Coast audiences as well as to earn her much needed revenue during the course of her lectures. Peabody and Winnemucca were successful in publishing the book shortly after its completion and Peabody circulated the

\footnotetext{
${ }^{9}$ Gretchen M. Bataille and Kathleen Mullen Sands, American Indian Women Telling Their Lives (Lincoln: University of Nebraska Press, 1984), 21.

${ }^{10}$ Canfield, Sarah Winnemucca of the Northern Paiutes, 203.

${ }^{11}$ Zanjani, Sarah Winnemucca, 239.

${ }^{12}$ Letter from Winnemucca to General O. O. Howard, December 27, 1881. Sarah Winnemucca Hopkins to General Oliver Otis Howard. Oliver Otis Howard Papers, 1833-1912. The George J. Mitchell Department of Special Collection and Archives, Bowdoin College Library.
} 
book among her influential friends in Congress. A recent biography by Zanjani has noted the text's other possible purposes in collaborating to get her story told. First, the "choice of form also conformed to the Indian view that relating one's personal story apart from the tribe is distasteful" and that she may have attempted to "preserve the memory of her people, fulfilling the traditional role of an Indian woman as the keeper of knowledge for future generations. While multiple factors played into Winnemucca's choices regarding event inclusion or details of self-portrayal, these choices bolster my approach to the text as a targeted political narrative written to achieve certain ends. When Winnemucca went to Boston in 1883 she had been married to a white man named Lewis Hopkins for two years - a discharged soldier from the U.S. Army - though little is known about their relationship and the role he played during her lecture circuit years in Boston. ${ }^{13}$ The only sentence she refers to him in her book is the last sentence of her narrative that reads, "After my marriage to Mr. Hopkins I visited my people once more... and they urged me again to come to the East and talk for them, and so I have come." 14 Throughout her narrative Winnemucca refers to herself as Sarah Winnemucca - thus when I reference her in this thesis I will call her Winnemucca. However, Winnemucca published her book under the name Sarah Winnemucca Hopkins and most of the newspaper articles written about her during her time in Boston refer to her as Mrs. Hopkins. Winnemucca's choice to use her white married name to publish her narrative strengthens my argument that her

\footnotetext{
${ }^{13}$ San Francisco newspapers reported that Winnemucca and Lewis Hopkins were married at the Russ House, a San Francisco Hotel, on December 5, 1881. "The 1906 earthquake and fire destroyed San Francisco marriage records, and it is not clear how this union could have been formalized under California's miscegenation law." Quoted in Zanjani, Sarah Winnemucca, 226. ${ }^{14}$ Hopkins, Life Among the Piutes, 246.
} 
book was written as a political narrative to achieve certain ends. Winnemucca probably used her white married name to bolster her perceived respectability among whites and therefore her political message.

The scope of this project has constrained my elaboration on the ways in which as a cultural broker Winnemucca's personal life evidenced the two cultures she straddled. Though I argue that Winnemucca had a keen understanding of Victorian womanhood from a very young age and projected this identity in her narrative and with her public voice - she did not strictly adhere to Victorian womanhood constructs in her personal life. Regardless of what white society might expect of her, Winnemucca chose to approach her public womanhood as a Paiute. To cite one example, as a Paiute woman Winnemucca had distinct notions about what womanhood meant. Indeed knowledge and kinship ties rather than gender tended to structure social authority in her world. During her lifetime Winnemucca married or had serious liaisons with six men from the time she was sixteen until the death of her last husband in 1887. This is not surprising considering Paiute marriage customs. For the Paiute, environment dictated family relationship patterns, and kinship ties were crucial for survival. Of Paiute marriage, anthropologist Knack noted that "Parents arranged first marriages for both sons and daughters...but premarital sexual experience was common and uncensored for both boys and girls. Polygyny was rare and often sororal; polyandry occurred as a tolerated although very rare marital form...Divorce was frequent and available equally to men and women on the 
same grounds. Subsequent remarriages were individually arranged."15 Paiute marriage norms certainly offered more equality and freedom than Victorian standards. This description of marriage and the equality and sexual patterns embodied in it are the expectations Winnemucca brought to her relationships with men. She knew the freedom Paiute women enjoyed within the Paiute social structure regarding marital choice making, and chose to live her life via the freedoms she understood of Paiute womanhood rather than the constraints Victorian womanhood presented.

This thesis is also admittedly narrow in scope in that I have constrained it to a gendered settler colonial lens through which I evaluate Sarah Winnemucca's public voice. Life Among the Piutes is a complex text, and as stated in its forward by Catherine S. Fowler, its author "was also a very complex person living in complex times and making complex decisions." I cannot with academic seriousness pretend to understand all of the nuances and motivations behind each of the individual choices that Winnemucca made throughout her life, and I do not attempt in this text to dissect her actions through a multitude of lenses. The reader may find this to be - as I have - a potential weakness of this work. In studying Winnemucca's life I have come to agree with historian David Lewis who writes in his article, "Reservation Leadership and the Progressive-Traditional Dichotomy," about the weakness of the "traditional" vs. "progressive" dichotomy that frequents scholarship on bicultural brokers within tribal

15 See Martha C. Knack's article, “The Dynamics of Southern Paiute Women's Roles," in chapter nine of Women and Power in Native North America. Laura F. Klein and Lillian A. Ackerman, eds., Women and Power in Native North America (Norman: University of Oklahoma Press, 1995), 149. 
communities especially since it obscures the work of "complex individuals, particularly the intermediaries, the middlemen, the cultural broker." The scope of this project has allowed me to evaluate Winnemucca through the lens of the settler colonizer, although as a complex cultural broker Winnemucca's life and work deserves much more analysis and nuance than I am able to parse in this thesis. But by concentrating on Winnemucca's public voice as conveyed in her political text as well as her lectures using a gendersensitive lens I argue that Life Among the Piutes: Their Wrongs and Claims is not a diary, or even an autobiography, but as the title suggests, it is a political text and, I add, one characterized by oppositional conformity. In making this argument it is not my intention to neglect the richness of the narrative for its multi-faceted contributions to Native American women's history as well as other disciplines.

When Winnemucca's public voice is assessed as a tool to achieve a set of political objectives, it becomes clear that Winnemucca masterfully maneuvers in and out of widely circulating literary and cultural stereotypes of the nineteenth century United States. In her book Authentic Indians: Episodes of Encounter from the Late-NineteenthCentury Northwest Coast, Paige Raibmon argues:

Natives and non-Natives... became unequal collaborators in the creation of enduring binaries that cast aboriginal people as the antithesis of their colonizers... Whites generally agreed that Indians "were traditional, uncivilized, cultural..., static, part of nature and of the past. Whites, on the other hand, were modern, civilized, political..., dynamic, part of society and of the future...' Native people engaged these false dichotomies with a range of self-representations that frequently challenged yet ultimately confirmed white expectations...authenticity was a structure 
of power that enabled, even as it constrained, their interactions with the colonial world. ${ }^{16}$

It is these challenges, especially around issues of women and gender, that I focus on in this thesis.

Winnemucca's target audience for her narrative was white middle-class reformers in the East. During her public career she often engaged in self-representations that fell into the binary Raibmon describes, but Winnemucca used this binary as a means to strengthen her influence over her audience, empowering rather than entrapping herself through skillful maneuvering.

I argue that Winnemucca's narrative, Life Among the Piutes, is a political text of oppositional conformity. Life is a narrative of conformity because it employs the rhetoric of the colonizer in order to cultivate white audience receptiveness. Simultaneously Life is a narrative of opposition, because it harshly criticizes whites for their treatment of Native Americans and rejects complete assimilation to either national citizenship or conversion to Christianity. This thesis asserts that Winnemucca's choice to tell her story via the rhetoric of the colonizer was politically productive, and gained her audiences, newspaper coverage and a book readership. Further, I assert that Winnemucca's literary and political strategy is more appropriately characterized as oppositional conformity rather than self-contradictory or ambiguous.

\footnotetext{
${ }^{16}$ Paige Raibmon, Authentic Indians: Episodes of Encounter from the Late-NineteenthCentury Northwest Coast (Durham, NC: Duke University Press, 2005), 7, 11.
} 
Using her public voice Winnemucca painstakingly strove to connect - and sometimes disconnect - a number of issues that commonly structured mainstream beliefs about Native Americans, colonialism, and citizenship. Winnemucca employed multiple political messages and strategies to cut away at Euro-American settlers' moral justifications for colonialism. Winnemucca also articulated her own vision of "citizenship" mainly defined as a mutual abiding by the rule of law rather than shared national identity. She also sought to find common ground with white middle-class reform audiences regarding English-language education and sexual virtue and family morality. Simultaneously she challenged whites' foundational understandings of citizenship as including individualism and Christianity.

As Winnemucca's reform efforts progressed over time, her voice regarding Indian women's sexuality and the rape of Indian women grew louder. Unlike her biographers, who mostly overlook Winnemucca's assault on stereotypes about Indian women's sexuality, I argue that her consistent focus on this theme is crucial to her lived context. Moreover, the personal attacks on Winnemucca's morality from government officials and reformers alike are one of the primary reasons, I argue, she combated this identity so fiercely with her public voice. Finally, I argue that ultimately personal accusations as well as her inability to escape the "heathen" identity forced on Indians by Christian reformers thwarted the success of Winnemucca's political message. 


\section{CHAPTER ONE}

\section{SARAH WINNEMUCCA'S OPPOSITIONAL CONFORMITY}

Sarah Winnemucca's Life Among the Piutes [sic]: Their Wrongs and Claims, published in 1883, was the third autobiography written by a Native American and the first by a Native American woman to be published in the United States. ${ }^{1}$ The book combines autobiography, ethnography, and a history of Paiute-white relations. Life spans roughly four decades from 1844 to 1883 . It was written and published during the Era of Assimilation, a period of intense pressure on native people to abandon traditional lands, migratory patterns, and forms of family and tribal life and adopt white systems of land ownership, patriarchy and agriculture. This thesis argues that Winnemucca's narrative is a political text of oppositional conformity, a political strategy especially evident in her use of gender norms, constructs, and moral claims on her readers. In contrast to the handful of scholars who have interpreted Winnemucca in the last ten years, I emphasize the intersection of race and gender ideologies in a colonial context. Thus, I refer to and extend the theorizing of Gregory Wright, who posits that, "Winnemucca employed the rhetoric of the colonizer to counteract Native American cultural constructs prominent in

\footnotetext{
${ }^{1}$ A. LaVonne Brown Ruoff and Jerry W. Ward, "Three Nineteenth-Century American Indian Autobiographers," in Redefining American Literary History (New York: The Modern Language Association of America, 1990), 261.
} 
the nineteenth century." 2 Life is a narrative of conformity because it employs the rhetoric of the colonizer in order to cultivate white audience receptiveness. Simultaneously Life is a narrative of opposition, because it harshly criticizes whites for their treatment of Native Americans, and mobilizes strong gendered and raced norms of morality, piety, and worth in order to do so.

To be sure, historians and literary scholars have been "gender sensitive" in their approaches. Referring to Winnemucca, Carolyn Sorisio maintains the position that, “Winnemucca's contradictory and multiple self-representations formed much of her resistance." Cari Carpenter labels Winnemucca a "hybrid," or one who is in "a migratory state of constant motion, ambiguity, and contradiction." ${ }^{4}$ Rather than arguing that Winnemucca was an ambiguous figure of contradiction in constant motion, I build on scholarship more sharply focused on colonial relations, like that of Antonia Castañeda who placed sexual violence against women as a key and enduring feature of colonialism in the Americas. ${ }^{5}$ An important effect of this reframing was to push back against the

${ }^{2}$ Gregory Wright, “(Re)Writing the Captivity Narrative: Sarah Winnemucca's Life Among the Piutes Records White Male Sexual Violence," Nevada Historical Society Quarterly 51, no. 3 (Fall 2008): 200.

${ }^{3}$ Carolyn Sorisio, "Playing the Indian Princess? Sarah Winnemucca's Newspaper Career and Performance of American Indian Identities," Studies in American Indian Literatures 23, no. 1 (May 14, 2011): 3.

${ }^{4}$ Cari Carpenter, “Tiresias Speaks: Sarah Winnemucca's Hybrid Selves and Genres," Legacy 19, no. 1 (2002): 72.

${ }^{5}$ In her article, "Women of Color and the Rewriting of Western History," Castañeda argues that, "Understanding the nature of gender systems...is critical to understanding...conquest and colonialism and why women responded and acted the way they did in intercultural settings and relationships... The devaluation of the sexuality of women of color, and by extension the devaluation of their people, was an important element in the rationale for war, conquest, exploitation, and subsequently exclusion. It was - and remains - a central part of the racist 
negative view of the Native American woman as a degraded "squaw" oppressed by her “own" menfolk - during what historians sometimes refer to as the Era of Assimilation (roughly 1807-1890). Read through this lens, Winnemucca's narrative becomes a pioneering attempt to name the unnamable: the systematic violence against Indians and the rape of Indian women as mechanisms for colonial domination. ${ }^{6}$ Because Winnemucca seeks out this naming during America's Victorian Era's highly constrained and gendered discourses about the body and power, she uses the dominant discourse of "True Womanhood" as the container for her story of wrongs done to her people.

\section{Winnemucca's Public Voice During the Era of Assimilation}

For a number of tribes in the east, like the Cherokee, the Civil War and Reconstruction raised the stakes for citizenship through questions revolving around

\footnotetext{
argument that served the political and economic interests of an expansionist United States." Antonia I. Castañeda, "Women of Color and the Rewriting of Western History: The Discourse, Politics, and Decolonization of History," Pacific Historical Review 61, no. 4 (November 1992): 519.

${ }^{6}$ For more information see the following: Castañeda, "Women of Color," 501-533. Antonia I. Castañeda, "Gender, Race and Culture: Spanish-Mexican Women in the Historiography of Frontier California," Frontiers: A Journal of Women's Studies 11, no. 1 (1990): 8-20. Bonita Lawrence, "Gender, Race and the Regulation of Native Identity in Canada and the United States: An Overview," Hypatia 18, no. 2 (Spring 2003): 3-31. Karin Morin, "British Women Travelers and Constructions of Racial Difference across the Nineteenth-Century American West," Transactions of the Institute of British Geographers, New Series 23, no. 3 (1998): 311-330. Gregory D. Smithers, "The 'Pursuits of the Civilized Man': Race and the Meaning of Civilization in the United States and Australia, 1790s-1850s," Journal of World History 20, no. 2 (2009): 245272. Wright, "(Re)writing the Captivity Narrative," 200-218.
} 
military service and the end of slavery. ${ }^{7}$ For the Paiutes, however, located further west (in the Great Basin region of Nevada) significant contact with whites began much later and questions of citizenship did not center on Civil War participation or rights accrued under Reconstruction legislation. Born in 1844, and having encountered whites for the first time in 1851, Winnemucca spent the first thirty years of her life negotiating Indian space between rapidly encroaching frontiersman and soldiers. ${ }^{8}$ Winnemucca gained her public voice and gave her first lecture on the plight of her people in 1879. It was largely due to a string of publicized government wrongs against Indians by Eastern Christian reformers, when audiences on the East and West Coasts evinced a new interest in the socalled "Indian Problem," tired, as some were, of the "Negro Problem" that had supposedly plunged the country into the chaos and violence of Reconstruction. As Senier has pointed out, "Indigenous populations were in fact keenly visible in the decades following the Civil War, as a rapidly westward expanding population began to press more adamantly at the borders of reservations." When Winnemucca began her lecture career on the Indian cause, formal citizenship was more frequently an agenda item of her white female reformer and educator allies, who in part adopted the Indian cause to advance their own citizenship agendas. ${ }^{10}$ Another contribution of this thesis, compared to other

\footnotetext{
${ }^{7}$ George E. Frizzell, "Politics of Cherokee Citizenship, 1898-1930," North Carolina Historical Review 61, no. 2 (April 1984): 205-230.

${ }^{8}$ Sally Zanjani, Sarah Winnemucca (Lincoln: University of Nebraska Press, 2001), 17, 26.

${ }^{9}$ Siobhan Senier, Voices of American Indian Assimilation and Resistance: Helen Hunt Jackson, Sarah Winnemucca, and Victoria Howard (Norman: University of Oklahoma Press, 2001), 6.

${ }^{10}$ For more information see Allison L. Sneider, Suffragists in an Imperial Age: US Expansion and the Woman Question 1870-1929 (New York: Oxford University Press, 2008), especially the chapter titled. "Western Expansion and the Politics of Federalism: Indians, Mormons, and Territorial Statehood, 1878-1887."
} 
treatments of Winnemucca, is to recover and explore Winnemucca's critique of formal citizenship as part of a solution to the "Indian Problem." Indeed, her diffidence about individual citizenship and voting in favor of tribal rights and control over native lands explains a good bit of the obscurity of her legacy in historiography, driven as much of it is with nationalist concerns with first-class citizenship rights.

Winnemucca's narrative, the main imprint of her thinking, has been controversial in this regard since its publication in the 1880s. Winnemucca's narrative has been criticized by scholars as well as by her own people for promoting Indian assimilation and even for staunchly supporting the General Allotment Act, or the Dawes Act, at the expense of the cultural integrity of the Paiutes. ${ }^{11}$ That is, she put land ahead of all other components of "rights." Against and beyond this view, however, this thesis suggests that to veil her criticisms of Euro-American assimilation ideas and champion the Paiute cause, Winnemucca strategically uses Indian conformity and assimilated Indian personae -notably the ideal of the good daughter -- to cultivate audience reception, while she simultaneously counters stereotypical Indian identity and resists notions of indigenous people fully assimilating into the Euro-American cultural mainstream. As Karen Morin has succinctly stated, representational tropes common among Euro-Americans regarding Native Americans ranged from "revulsion at Native 'savagery'; to romanticization of the primitive but 'vanishing' American; to moralistic reform-minded concern for the abused

\footnotetext{
${ }^{11}$ The General Allotment Act is generally understood as radically reordering, remaking and disempowering Indian people in the U.S. due to its land and citizenship policies tied largely to Christian and European legal family norms. Senier, Voices of Assimilation and Resistance, 80.
} 
squaw and her corollary, the Indian Princess..." 12 But whatever the stereotype Native Americans held in whites' purview, it was almost unanimously agreed upon throughout the Era of Assimilation that the only thing "to do" with Native Americans was to assimilate them into Euro-American society. ${ }^{13}$ In important ways Winnemucca tried to steer toward another possible outcome. Making an uneasy peace with assimilation, Winnemucca uses whites' language of proper family relations and stresses the importance of native English language literacy as a route for preserving a future for her people. That is, family relations, rather than liberal constructs of individual rights, are the principal - and gendered - vehicle for Paiute claims on the state. ${ }^{14}$

Historian Frederick Hoxie has pinpointed the Era of Assimilation's beginning in 1879 when several widely publicized tragedies garnered non-Indian sympathy for American Indians. The Era of Assimilation culminated in 1887 with the General Allotment Act (the Dawes Act) - legislation designed to divide communally held tribal lands into individual allotments. This act echoed public sentiment of the need for Indians to cease existing as collective entities and become individual landowners assimilating to Euro-American agriculture and capitalism. ${ }^{15}$ Under the Dawes Act, land allotments went

\footnotetext{
${ }^{12}$ Morin, "British Women Travelers," 312.

${ }^{13}$ Senier, Voices of Assimilation and Resistance, 3.

${ }^{14}$ Elsa Barkley Brown cites similar ideals among black communities regarding freedom. She writes, "African Americans throughout the South in the post-Civil War period emphatically articulated their understanding that freedom and autonomy could not be independently achieved...individual freedom could be achieved only through collective autonomy." Elsa Barkley Brown, "To Catch the Vision of Freedom: Reconstructing Southern Black Women's Political History, 1865-1880," in Unequal Sisters: An Inclusive Reader in U.S. Women's History, $4^{\text {th }}$ ed. eds. Vicki L. Ruiz with Ellen Carol DuBois (New York: Routledge, 2008 ), 157.

${ }^{15}$ Senier, Voices of Assimilation and Resistance, 5.
} 
to "heads of households," thus exerting a powerful and distinct gender pressure on native people. Feminist historians and anthropologists acknowledge that Christian marriage subordinated native women to their husbands by law and generally undermined their traditional access to and authority over land and productivity, which generally accrued to men under the General Allotment Act. Although single women and widows were sometimes allotted and wives were occasionally co-allotted land under Dawes, the imprint of coverture and ideal of dependency and protection for wives has been widely remarked by historians of Native America. ${ }^{16}$

Winnemucca died in 1891, roughly four years after the passage of the Dawes Act. At that time the Dawes Act had still not been officially instituted among her people. ${ }^{17}$ Winnemucca understood that, in the 1880s, Euro-Americans were pushing for Indians' cultural adaptation to individualism and capitalism. Yet, in her narrative, she eschews Euro-American ideas of individualism and capitalism and reinforces Paiute traditions of collective landholding and communalistic living. Historians consider the Era of Assimilation over in 1934 with the "Indian New Deal," or the 1934 Indian Reorganization Act. The Indian Reorganization Act was an "act aimed to give American Indian peoples more autonomy by recognizing their right to set up their own constitutions

\footnotetext{
${ }^{16}$ Theda Perdue, "Native Women in the Early Republic: Old World Perceptions, New World Realities," in Native Americans and the Early Republic, eds. Frederick E. Hoxie, Ronald Hoffman and Peter J. Albert (Charlottesville: University Press of Virginia, 1999), 85. See also Katherine M. B. Osburn, “'Dear Friend and Ex-Husband”": Marriage, Divorce, and Women's Property Rights on the Southern Ute Reservation, 1887-1930," in Negotiators of Change. ed. Nancy Shoemaker (New York: Routledge, 1995).

${ }^{17}$ The executive order making Fort McDermitt the official reservation of the Paiutes came in 1889 , and the Paiutes officially received government allotment in 1892. Zanjani, Sarah Winneтисса, 285.
} 
and operate under governments of their own design." 18 Thus, in a way, the Indian Reorganization Act "formally" ended individualistic government assimilationist policies. However, as Senier points out, "Despite dramatic changes in U.S. Indian policy between 1887 and $1934 \ldots$ white attitudes toward American Indians ultimately changed little...whether Indians were envisioned as potential yeoman farmers, as in the 1880 s, or as permanent underclass, as they came to be by the 1930s, they were always to be contained within Euro-American norms," gender among them. ${ }^{19}$

Against this backdrop of policies and attitudes of assimilation, Winnemucca played to Euro-American expectations by consistently representing her behaviors to both native and Anglo audiences as doing her duty on behalf of her grandfather Truckee (leader of the Winnemucca tribe), her father Winnemucca (leader of the tribe following Truckee's death), and her brothers Lee and Natchez; she thus sanctioned her public voice within recognizable "patriarchal" male authority. [Her approach is not inconsistent with her Paiute upbringing - because kinship networks were so central to the Paiute, Winnemucca may be placing herself into a lineage of powerful leaders as a way to situate her own authority in a way that makes cultural sense to her.] As a narrative targeted at white audiences, however, her approach is also consistent with Euro-American norms of the time period. Representing themselves on behalf of the patriarchy was a common way

\footnotetext{
${ }^{18}$ Senier, Voices of Assimilation and Resistance, 7.

${ }^{19}$ Ibid., 8.
} 
for euro-American women to speak publicly in the nineteenth century. ${ }^{20}$ Few scholars have noted, however, that in her narrative Winnemucca also finds her own voice by following the example of and remedying the frustrations of her own mother - a mother who tried desperately to protect her daughter from rape.

\section{Winnemucca Mobilizes “True Womanhood” Ideology}

Winnemucca was an Indian woman writing to white middle-class Christian audiences -- an outsider trying to gain acceptance in alien territory. Her narrative was aimed at re-situating the Paiutes within white societal constructs and exposing white cruelty, while simultaneously making space for Paiute world views, values and norms. In order to do this the narrative reinforces certain aspects of Paiute identity, especially Paiute women's identity, that coincide to some extent with expectations of white civilization. Accepted notions of Euro-American womanhood during the nineteenth century fell in line with notions of "True Womanhood." Nineteenth century True Womanhood ideals, "by which a woman judged herself and was judged by her husband, her neighbors and society could be divided into four cardinal virtues - piety, purity, submissiveness and domesticity." ${ }^{21}$ In a world where "God's chosen men" were busy turning vast new lands into a personal wealth generating machine, white women were put in charge of retaining religion, tradition and remembering God. Female ascribers to this

\footnotetext{
${ }^{20}$ Louise Newman, White Women's Rights: The Racial Origins of Feminism in the U.S. (New York: Oxford University Press, 1999).

${ }^{21}$ Barbara Welter, "Cult of True Womanhood: 1820-1860," American Quarterly 18, no. 2 (Summer 1966): 152.
} 
ideology believed that God had made them this way in order that they might help to uplift and save a rapidly spiraling wicked world. ${ }^{22}$ In order to be heard as rational and deserving, Winnemucca's narrative had to convey some sort of fluency with white women's rules of propriety.

Importantly, Winnemucca was not addressing her story primarily to her own people, or even to a skeptical audience of peers. Winnemucca wrote her narrative hoping that its publication would reach a wider audience than she could reach through her lecture circuit. She also wrote it to tell a more complete story than she could tell in the few hours that she had available to her during her lectures; indeed the narrative retains some connection to its earlier life in public performance and orality, mainly through the use of repetition. The text was written after many of the events Winnemucca recounts had already transpired and serves to legitimize Winnemucca's actions retrospectively as well as to bolster her political stance of oppositional conformity among Indian reformers, government agents, and the soldiers among whom she moved. In order to recount her tale Winnemucca had to speak to white audiences through the auspices of varying acceptable personae - personae her white Christian audiences could identify with and would approve of.

${ }^{22}$ Ibid. 


\section{Telling Her Story through Acceptable Personae}

Winnemucca, the heroine of the narrative, skillfully adopts four personae through which to speak. Each of these strategically assimilative personae conforms to either white notions of Indian identity or white notions of acceptable behavior for EuroAmerican women. ${ }^{23}$ Always narrating in the first person, Winnemucca nimbly moves through the portals of self-portrayal as (1) the noble and beautiful Paiute Indian princess ambassador worthy of both the affections of white men and the attention of white audiences, (2) the mother of the Paiute nation who protects her people and wields motherly influence within her tribe, (3) a humble Indian woman who defers to men (her brother, her father, and military officers) for advice and guidance, and (4) the moral warrior who takes upon herself the responsibilities to do what others will not do to protect her people, a kind of heroic figure that would resonate with Biblical figures like Esther or Deborah. These Indian assimilation portrayals allow Winnemucca to expose white brutality, counter stereotypical Indian identity and make a case for resistance to full Indian assimilation into Euro-American society.

Dedicated mostly to Paiute-white relations, this entirely self-narrated book is comprised of three distinct sections. Part 1, the first forty pages and first chapter of the book, describes Winnemucca's family as well as Winnemucca and her tribes' initial devastating contacts with whites. In 1849 the draw of California gold, Idaho ore

\footnotetext{
${ }^{23}$ This is not to say the personae Winnemucca adopts are necessarily inconsistent with Paiute culture or tradition. This section merely underscores how the personae Winnemucca describes to her white audience conform to white notions of acceptability.
} 
deposits, and Oregon timber led hordes of settlers through Winnemucca's homeland - the Great Basin region of present day Nevada, California and Oregon. Part 1 chronicles the destructive impact of early white settler migration on Winnemucca's and Paiute life. Part 1 also highlights the multiple attempted rapes of Winnemucca's older sister, Mary, by white men. Winnemucca refers to Mary's stories throughout her narrative and uses them as proof of Indian women's virtue and victimization. ${ }^{24}$ By establishing her moral authority in girlhood, Winnemucca is more likely to be viewed as a victim rather than a “sneaky" or "vengeful” adult "savage." Part 2, a second chapter consisting of a mere thirteen pages, describes the "Domestic and Social Moralities" of the Paiutes. ${ }^{25}$ This short chapter contains ethnographic information about the Paiute tribe. Filled with excerpts like, "We don't marry into our relations... The chiefs do not live in idleness...There is nothing cruel about our people. They never scalped a human being," Part 2 of Winnemucca's narrative addresses Indian and white cultural similarities and pushes back against the charge of barbarism and savagery made against Indians by whites. $^{26}$ More purposefully than just doling out Paiute ethnographic information, Senier points out that Indian writers "who addressed assimilation critically were not primarily interested in representing tribal practices for the non-Indian readers who comprised much of their audience. They were more interested in re-structuring the relations between

\footnotetext{
${ }^{24}$ Ruoff, Redefining American Literary History, 262.

${ }^{25}$ Sarah Winnemucca Hopkins, Life Among the Piutes: Their Wrongs and Claims (Reno: University of Nevada Press, 1994), 45-57.

${ }^{26}$ Ibid., 45, 54.
} 
Indians and non-Indians. ${ }^{, 27}$ This is true of Winnemucca and this point may explain her short ethnographic chapter. Winnemucca is not primarily concerned with explaining Paiute culture to her audience; her ethnographic chapter capitalizes on Indian/white cultural similarities in order to champion Paiute traditionalism and sovereignty. Part 3, the remaining six chapters and one hundred fifty-two pages, describe white-Paiute conflicts from 1860-1883. Making up the bulk of her autobiography, Part 3 records the injustices Winnemucca's people suffered at the expense of white settlers and corrupt Indian agents, and the Paiutes' struggle to maintain their homeland. In Part 3 Winnemucca attacks the reservation system and corrupt Indian agents, pointedly addresses the rape of Indian women by white men, exposes white settler ruthlessness and dishonesty, and heavily advocates Paiute sovereignty. Boldly, she places blame for the Paiute's struggles and instability on whites. In order to tell this tale of white brutality and Paiute innocence Winnemucca's narrative of oppositional conformity relies heavily on her four assimilative personae to maintain audience reception.

Winnemucca is adroit at the technique of adopting various and believable selfportrayals, and in her narrative she is private and public, masculine and feminine. ${ }^{28}$ Depending on the political purpose of the story she is telling, Winnemucca draws on the most strategic of these personae and sometimes multiple personae in order to legitimize her actions, prove the truthfulness of her words, or dramatize the event. Her chosen

\footnotetext{
${ }^{27}$ Senier, Voices of Assimilation and Resistance, xiii.

${ }^{28}$ Kathleen Mullen Sands, American Women's Autobiography, ed. Margo Culley (Madison: University of Wisconsin Press, 1992), 277.
} 
feminine personae of humble Indian woman, noble Indian princess ambassador and mother of the Paiute nation, make her simultaneously personable and a spectacle. Her masculine persona of moral warrior makes her a heroine acting on behalf of others, selfsacrificing rather than self-promoting. These varying personae create powerful and flexible identities that make the biting words and criticisms of Winnemucca's narrative palatable to white audiences. Strategically, Winnemucca begins her narrative as a terrified Indian girl and ends it as a devoted teacher of Indian children, leaving the reader with a picture of her as a motherly figure dedicated to uplifting her race, a formulation highly regarded and strongly advanced by her reform-minded Protestant audiences, albeit to other purposes (namely colonialism).

\section{Paiute Princess Ambassador Persona}

On the first page of her narrative Winnemucca establishes the lineage that makes her an Indian princess - she is the granddaughter and later the daughter of the chief of the Paiutes. Kinship, especially daughterhood, is the foundational and essential enabling category for the bulk of the narrative. She writes, "My grandfather was chief of the entire Piute nation." ${ }^{29}$ Five pages later, Winnemucca bolsters her "princess" identity by confirming that her father was charged with chieftainship whenever her grandfather had to travel away from her band. Winnemucca writes, "My grandfather told my father to take charge of his people and hold the tribe, as he was going back to California... So my

${ }^{29}$ Hopkins, Life Among the Piutes, 5. 
father took his place as Chief of the Piutes..." ${ }^{30}$ Later she confirms that when her grandfather died he gave charge of the Paiute nation to her father. Of her grandfather's death she recorded him to have said, "I've only a minute to spare. Now, son, I hope you will live to see as much as I have, and to know as much as I do. Do your duty as I have done to your people." ${ }^{\prime 3}$ In her narrative Winnemucca's chief grandfather conferred the duties of chiefdom early and often on his son, Winnemucca's father, and finalized her father's chieftainship on his own deathbed.

The identity of Indian princess can be viewed as a tactic Winnemucca uses in her narrative to gain the respect of white audiences, for chieftainships did not exist among many Indian tribes before white contact - especially the Paiute bands. ${ }^{32}$ Winnemucca mobilizes the notion of properly sanctioned, dutiful daughterhood to justify her behaviors and her authority to assert a public voice. Before encountering whites, Winnemucca's people's political structure consisted of complex network of kin relationships in which political and economic factors weighed heavily in family relations. They referred to themselves as people. Canfield writes that before white contact, "they called themselves simply the Numa, or 'People.",33 In this context, family and kinship were especially important in terms of solidifying political relationships and economic and social alliances. Paiute band size depended on a number of variables including the personality

\footnotetext{
${ }^{30}$ Ibid., 10.

${ }^{31}$ Ibid., 68.

32 James Gilbert Movius, "White-Paiute Conflicts," The Journal of the Shaw Historical Library 6 (1992): 37-38.

${ }^{33}$ Gae Whitney Canfield, Sarah Winnemucca of the Northern Paiutes (Norman: University of Oklahoma Press, 1983), 3.
} 
of the leader of the band, and usually consisted of 100-200 members. ${ }^{34}$ It was not until white contact that "chiefdoms" were created. On their way west, white settlers were expecting to work with tribal chiefs. Consequently, this is how whites treated band leaders among the Paiutes. ${ }^{35}$ Winnemucca's lineage, as understood by whites, meant little to her tribe - Paiutes understood that although her father and grandfather were clan leaders, as family followers with loosely based kinship ties all over the region they had freedom to identify at will with any of the varying Paiute clans in the Great Basin region. Nonetheless, Winnemucca stresses family as a point of political entry to various aspects of the colonial project unfolding around her. Winnemucca uses whites' understanding of chieftainship and lineage to gain her readers' attention and make a case for why whites should listen to her. Solidifying that she is the daughter of the chief of the Paiute nation makes Winnemucca more than just an Indian woman; she is an Indian princess. Here Winnemucca plays into white stereotypical notions of the "Indian princess" to become not only a spectacle that rouses attention but an ambassador for her tribe. ${ }^{36}$

The Indian princess identity takes Winnemucca out of the realm of ordinary Indian woman and places her and her family in the same category as the elite ruling monarchs of earlier centuries. An April 1883 Boston Evening Transcript article entitled,

\footnotetext{
${ }^{34}$ Martha C. Knack and Omer C. Stewart, As Long as the River Shall Run: An Ethnohistory of Pyramid Lake Indian Reservation (Berkeley: University of California Press, 1984), 15, 22.

${ }^{35}$ Movius, "White-Paiute Conflicts," 38.

${ }^{36}$ Green asserts the changing image of the Indian princess construct over time. During Winnemucca's time the Indian princess construct became less associated with helping an individual white lover and more associated with helping whites in the form of medicine. Rayna Green, "The Pocahontas Perplex: The Image of Indian Women in American Culture," Massachusetts Review 16, no. 4 (Autumn, 1975): 698-714. See also Paula Gunn Allen, Pocahontas: Medicine Woman, Spy, Entrepreneur, Diplomat (San Francisco: Harper, 2003).
} 
"A Piute Indian Princess" suggests that the Paiute people were "perfectly obedient" to Princess Winnemucca's wishes. ${ }^{37}$ To bolster her authority among whites Winnemucca carefully delineates her political message as one aligned with the wishes of her father - a patriarchal authority whites were more likely to take seriously. In 1881 the New York Times ran an article entitled, "Indian Agents to Be Denounced, The Princess Winnemucca Coming East on a Lecturing Tour." In the article, Winnemucca is quoted to have said, "It is by the desire of my father, Winnemucca, chief of the Piutes that I go forth to lecture to the whites in the East. It is not so much for pecuniary gain that I make this Eastern tour, but with well-founded hope that what I say may tend somewhat to correct some erroneous impressions concerning the Western Indian tribes." The reporter asks, "You mean the Piutes?" To which she replies, "No, I mean all the Indians who are afflicted with that terrible pest - the Indian Agent. ${ }^{, 38}$ Here Winnemucca tells her white audience that she is not lecturing for money or to make profit for her family or particular tribe a stance that helps her seem "self-less" and feminine to her listeners - though as an Indian woman supporting herself she did need money and did charge for her lectures. She also clarifies that she has come because she is dutifully fulfilling the request of her father and she is speaking on behalf of not just the Paiutes but "all the Indians who are afflicted..." She then goes on to threaten war - as the ambassador of her tribe she tells the reporter, "I have notified the military authorities that our people were preparing for another outbreak, which will certainly occur if the Indian Agent up there at Pyramid Lake

\footnotetext{
${ }^{37}$ Sorisio, "Playing the Indian Princess," 10.

38 "Indian Agents to be Denounced," New York Times, December 18, 1881.
} 
is permitted to remain there and continue his present high-handed treatment of our people." ${ }^{39}$ Winnemucca's Indian princess persona, with its attached white notions of her patriarchal sanctioned authority and the importance of her lineage, justifies Winnemucca's involvement in Paiute political affairs. In reality Winnemucca's duties and actions were self-appointed. She did not have these responsibilities placed upon her because she was her tribes' "princess" or the daughter of their "chief."

\section{Paiute Mother Persona}

In her narrative, Winnemucca makes a key transition from "Paiute Indian princess" to "Mother of the Paiute tribe," when she recounts her participation in the Bannock War of 1878. When the Bannock War broke out Winnemucca had taken a job as a paid guide for a traveling white father and daughter - a Mr. Morton and his daughter Rosey. Winnemucca had agreed to take the Mortons in her wagon from the John Day Valley in Oregon to Silver City, Idaho. ${ }^{40}$ During this journey with the Mortons Winnemucca heard news that the Bannock Indian tribe had declared war on whites in the area and were holding some of her Paiute people captive, her father and brother among them, for aiding local whites to escape the warring Bannocks. Winnemucca immediately made preparations to leave the Morton family and go rescue her people. It is at this key juncture in her narrative that Winnemucca ascends from Indian princess to mother of the

\footnotetext{
${ }^{39}$ Ibid.

${ }^{40}$ Zanjani, Sarah Winnemucca, 150.
} 
Paiute tribe. Strategically, perhaps even protectively, left out of the picture is any mention of her own marriages or obligations to children within her tribe or extended family; rather it is as helper of the needy_-even of white folks_- that enables Winnemucca to move her public engagement to a fullest potential as a Mother figure.

As mother of the Paiutes, Winnemucca becomes endowed with more authority. No longer the Indian princess acting with the patriarchal sanction of her chief father, Winnemucca's motherly persona protects her people and wields influence within her tribe. Winnemucca takes on motherly qualities from the moment she finds out her people are in captivity. The radical potential of the mother role lay in the fact that she had no children or family of her own demanding her care; thus she could not be accused of neglecting her duties at home, the key grounding of "true womanhood" in the late nineteenth century. Her narrative records the conversation she had with Mr. Morton upon hearing the news about her people. "I ran to get my wagon ready. I told Morton and his little girl that I was to leave them, and the little girl began to cry. Her father talked to me and said, 'Sarah, don't leave Rosey, for she has come to love you.' I told him I had to work for my people. [Mr. Morton responded] 'Now, Sarah, as I have never talked to you before, will you be my wife? We will go to Silver City and get married right away." ${ }^{41}$ In this passage Winnemucca implies that Rosey has come to view her as a mother. And, as part of his reasons for offering Winnemucca marriage, Mr. Morton cites his concern for Rosey's attachment to Winnemucca as a mother figure. Winnemucca

\footnotetext{
${ }^{41}$ Hopkins, Life Among the Piutes, 151.
} 
turned down the marriage offer because she had to, "work for her people." She then rode off "at full gallop" toward the U.S. Army base where she would enlist herself as their scout and liaison between the Paiutes and the army. ${ }^{42}$ Even as she is riding toward her planned rescue, Winnemucca has begun to establish herself in a matronly light. Adopting a half grown child and widower gave her a kind of instant family, one that could shield her from moral suspicion but that did not completely compromise her ability to act in the public sphere. Arguably, this story suggests that working for "her people" might redound to the benefit of deserving, kindly white settlers.

The narrative then recounts the story of her rescue of her hostage father, brother and relatives. When Winnemucca finds her people in the Bannock camp she instructs them, "Yes, I have come to save you all if you will do as I wish you to and be quiet about it. Whisper it among yourselves. Get ready tonight, for there is no time to lose, for the soldiers are close by. I have come from them with this word: 'Leave the hostile Bannocks and come to the troops. You shall be properly fed by the troops.' Are you all here?"43 In this passage Winnemucca addresses not only her people but her father and brothers from a position of authority; yet her motherly persona acting on behalf of her people makes this authority palatable to her white readership. She is guiding her family to safety, and by casting herself in a motherly, protective light she has the authority to lead. She also includes that she has arranged for food for her people - as their mother she has become the provisioner/feeder of her people. Intelligently, Winnemucca's strategic

\footnotetext{
${ }^{42}$ Ibid., 151.

${ }^{43}$ Ibid., 160.
} 
choice of telling the story of the rescue of her people in succession with Mr. Morton's marriage proposal transitions her from dutiful daughter/princess to authoritative and lifesaving mother. Rosey's attachment to Winnemucca and Mr. Morton's marriage proposal recast her as the ultimate symbol of femininity: she is an Indian woman loved as a mother by a little girl and loved as a wife by a respectable white man. Winnemucca graciously turns down the marriage offer on behalf of her need to care for people. In other words, the story establishes her as true woman enough to perform normative wifehood and motherhood to "all," without curtailing her mobility and need to engage the public sphere.

Winnemucca strengthens her motherly persona by recounting events during the Bannock War in which she continues to act as a mother. When her people worry they will lose their homeland reservation when the war is over, Winnemucca narrates, "I said, 'Tell them I, their mother, say come back to their homes again. I will stand by them and see that they are not sent away to the Indian Territory.",44 Here Winnemucca asserts authority over her people's homes. Through her motherly persona she instructs her people to return home -- a domain that mothers are in charge of -- and promises them safety. Winnemucca is also ultimately responsible for the care of an orphaned Indian baby a white soldier finds on the battle field. Of the baby she wrote,

At this fight, a little girl-baby was found by a sergeant, who picked it up. I asked the woman I knew if she would be so kind as to look out and care for the baby for me. She said she would, and General Howard ordered

\footnotetext{
${ }^{44}$ Ibid., 182.
} 
some condensed milk for me, so that the woman might feed it, and I told her how to fix it. General Howard also told me to take good care of its little shirt and all its beads, and if they (the Bannocks) should ever surrender, we could find its mother. We had the little baby three months. ${ }^{45}$

Regarding the baby, Winnemucca takes charge and assigns the care of the baby to a woman she knows and then instructs the woman on how to prepare the baby's milk. She then asserts that she and this woman did not simply surrender responsibility for the baby, but took care of the baby for three months.

Although she cannot produce the key elements of motherhood, namely those of her "own" husband and children, Winnemucca's mother persona performs motherhood convincingly throughout the narrative's Bannock War chapter. She becomes the desired mother and wife of a white motherless family; rescues her people from the clutches of the warring Bannocks and secures their food source for the remainder of the war; takes responsibility for the safety for her people's home; and takes care of an orphaned baby. The Bannock War chapter, as told through Winnemucca's mother persona, appeals to the traditional family notions of her white audience, increasing her acceptability and by extension the acceptance of her message. As the next chapter will show, it was also a crucial shield against charges of immorality - namely, prostitution and gambling - which hounded Winnemucca in these same years.

\section{Humble Indian Woman Persona}

\footnotetext{
${ }^{45}$ Ibid., 180.
} 
To further blunt the transgressive elements of her reform work, Winnemucca's narrative uses the persona of a humble Indian woman to portray herself as a more-or-less assimilated feminine member of white society. While it was culturally necessary for a white woman working within the constructs of "True Womanhood" to defer to men for guidance when making decisions, Paiute women did not necessarily abide by these gender constructs. However, when strategically necessary in her political narrative of oppositional conformity, Winnemucca is found deferring to men for advice (both white and Indian) and asking them for permission.

Winnemucca plays a key role in Paiute/white interactions because she is an interpreter and often both men and women ask her to speak and/or write to whites or Indians on their behalf. As a translator and "go-between" for Paiutes and whites, Winnemucca's voice is often heard in the narrative and she has many opportunities to interject her opinions into the political milieu of Paiute/white relations; but she is careful to highlight situations in which she avoids a dominant and decisive self-portrayal. Winnemucca's humble Indian woman persona feigns humility and defers to men, notably around the potent and symbolic domain of English language literacy, a signal for “assimilated" Indian status. During a local white/Paiute conflict in 1865 some men in Winnemucca's tribe ask her to read a letter written to them by an Army captain of the opposing whites. Employing a humble Indian woman persona Winnemucca says, "It took me some time to read, as I was very poor, indeed, at reading writing; and I assure you, my dear readers, I am not much better now. After reading it... I knew what it said. 
I did not know what to do, as (my) brother had not returned."46 First, Winnemucca mentions that, in this situation, she did not know what to do because she needs to consult with her brother, who at the time is not present. Second, she feigns humility when it comes to reading and writing. In actuality, Winnemucca could read and write very well. She wrote many letters on behalf of her people and was called upon multiple times to read letters to them. ${ }^{47}$ She also documents in her narrative that she secretly read the correspondence of the Indian agents and the government. Though she is quite capable of "reading writing" Winnemucca feigns weakness in this area and portrays herself as a mere humble Indian woman trying to help her tribe - instead of the capable, selfeducated, Indian woman who would secretly read government correspondence when possible.

While difficult to determine completely, historians acknowledge that at a minimum, Winnemucca's formal schooling consisted of about three weeks at a convent school in San Jose, California. According to Winnemucca, she and her sister were "only there a little while, say three weeks, when complaints were made to the sisters by wealthy parents about Indians being in school with their children. The sisters then wrote to our friends to come and take us away, and so they did..."48 Historians have never really substantiated the details of her education, and much to her credit, Winnemucca taught

\footnotetext{
${ }^{46}$ Ibid., 82.

${ }^{47}$ As early as 1870 Winnemucca was writing letters to newspapers on behalf of her people. She also attempted to get cast off books from the California school system in an effort to teach her people how to read and write. See, "An Indian Girl's Letter," Gold Hill Daily News (Gold Hill, NV), April 28, 1870. See also, "An Indian Princess in the Sage Brush," Daily Alta California (San Francisco, CA), August 29, 1870.

${ }^{48}$ Hopkins, Life Among the Piutes, 70.
} 
herself how to read and write; she also learned Spanish as well as English and knew three Indian languages. ${ }^{49}$

During the Bannock War Winnemucca traveled with two white soldiers in search of her people. Although they were traveling through her home lands in search of signs of her people's whereabouts, Winnemucca records herself to have said, "What do you think?...You are men, you can decide better than I can.” Then, instead of just explaining that she knew the country better than the two white soldiers and that she should lead the way in search of her people, she has the two soldiers verbally acknowledge that she is more familiar with the country than they are and ask her to lead - a request she graciously accepts. ${ }^{50}$ Winnemucca deliberately uses her humble Indian woman persona to avoid appearing overbearing, decisive or masculine. Nineteenth Century white "True Womanhood" ideology demanded submission of women to men and Winnemucca shows her understanding of this white cultural gender construct by using a humble Indian persona whenever she might appear to be too decisive. Welter writes of "True Womanhood" ideology, "Submission was perhaps the most feminine virtue expected of women...men were the movers, the doers, the actors. Women were the passive, submissive responders. The order of dialogue was, of course, fixed in Heaven. Man was woman's superior by God's appointment, if not in intellectual dowry, at least by official decree." ${ }^{51}$ When using her humble Indian woman persona Winnemucca re-situates

\footnotetext{
${ }^{49}$ Zanjani, Sarah Winnemucca, 51.

${ }^{50}$ Hopkins, Life Among the Piutes, 156.

${ }^{51}$ Welter, "Cult of True Womanhood," 158.
} 
herself within the constructs of white civilization by acknowledging that the men in her life are in charge and are better equipped than her to make decisions on her behalf. In other words, Winnemucca's elaborate deference to men in her autobiography becomes necessary because her literacy enables her to push back decisively against the military and Indian agents who wielded words, names and papers with guile and duplicity.

Interestingly, this is the persona most at odds with Winnemucca's Paiute notions of womanhood. Paiute ideas of womanhood varied greatly from nineteenth century "True Womanhood" ideology. Sex equality was readily apparent among the Northern Paiute. "The status of each sex was...substantially equal...There were virtually no noneconomic activities which either sex would use as a social lever. The family therefore was a well-balanced bilateral unit, neither sex having appreciable advantage."52 The surroundings of the Great Basin territory made Paiute women and their work absolutely necessary for clan survival. Paiutes were skilled at natural resource utilization and at extracting life sustenance from their specific region of the country. Natural surroundings dictated that the Paiute people were tied to plant cycles, rather than animal migration. ${ }^{53}$ Clan numbers were small and, therefore, everyone's contribution to the clan mattered for survival. Women's work was essential. Knack writes, "Women worked with plants...Vegetables were far more reliable food sources than game...hence plants consisted a substantial portion of the annual diet... Both men and women individually

\footnotetext{
${ }^{52}$ Knack, As Long as the River Shall Run, 14. See also Martha C. Knack, Boundaries Between: The Southern Paiutes, 1775-1995 (Lincoln: University of Nebraska Press, 2001), 242.

${ }^{53}$ Knack, As Long as the River Shall Run, 16-17, 25.
} 
decided where they would concentrate their food-collecting efforts each day. With such freedom of action remaining with the individual, group leadership was rudimentary, adequate for the tasks of the society but not highly elaborated." 54 Before encountering whites, Winnemucca's people were not a nation but rather a traveling band of kinsman living in a world delineated by kin, stranger, and enemy. In his article, "White-Paiute Conflicts" historian James Movius notes, "The pre-contact (Paiute) bands were generally small in size and rather fluid in membership."55 Paiute groups splintered for varying reasons and individuals could choose to follow different Paiute leaders at will. ${ }^{56}$ This independence is evident in Winnemucca's autobiography. She traveled at will and stayed with loosely related kin all over the Great Basin territory.

The Paiute notions of gender that shaped Winnemucca's childhood were women and men who were independent, essential members of a clan and Winnemucca's life exhibits grounded notions of independence and clan cooperation. Winnemucca's native culture fostered strong leadership in women as well as in men. Women were and could be leaders in their varying bands. Knack writes,

They functioned in interband and intertribal trade. They were participants in the political process but not headman; they were important in the structure of residential groups, reckoned equally in kinship tracing, and had equal determination of their marital state. ${ }^{57}$

\footnotetext{
${ }^{54}$ Ibid., 22, 26.

${ }^{55}$ Movius, "White-Paiute Conflicts," 37-38.

${ }^{56}$ Hopkins, Life Among the Piutes, 9.

${ }^{57}$ Knack, As Long as the River Shall Run, 14. See also Knack, Boundaries Between, 151.
} 
Of women's political status within Paiute society Winnemucca writes, "The women know as much as the men do, and their advice is often asked. We have a republic as well as you. The council-tent is our Congress, and anybody can speak who has anything to say, women and all...If women could go into your Congress I think justice would soon be done to the Indians." 58 Thus, Winnemucca was a practiced participant in clan politics well before she appointed herself emissary of Paiute/white relations and skillfully puts in a good word for white citizen women who seek first class citizenship rights. ${ }^{59}$ And as we shall see, Winnemucca's learned English language literacy extended her power in politics in both white and Paiute worlds, but it also tainted her reputation among her people through misunderstandings and other entrenched inequities.

Within Paiute society divorce was frequent and available equally to men and women on the same grounds, and subsequent remarriages were individual decisions. ${ }^{60}$ Winnemucca's marriages also characterize the independence Paiute women experienced regarding marriage decisions. Winnemucca married multiple times. Her first two marriages were short lived and ended in divorce. ${ }^{61}$ She was later married to an Indian for a short time, and the only source that confirms this is a brief newspaper article; she does

\footnotetext{
${ }^{58}$ Hopkins, Life Among the Piutes, 53.

${ }^{59}$ Dolores Janiewski, 'Giving Women a Future: Alice Fletcher, the 'Woman Question,' and 'Indian Reform,"' in Visible Women: New Essays on American Activism, eds. Nancy A. Hewitt and Suzanne Lebsock (Urbana, Il: University of Illinois Press, 1993), 325-347. See also Newman, "Chapter 5: Assimilating Primitives: The 'Indian Problem' as a 'Woman Question," in White Women's Rights, 116-132.

${ }^{60}$ Knack, As Long as the River Shall Run, 14. See also Knack, Boundaries Between, 149.

${ }^{61}$ Zanjani, Sarah Winnemucca, 142.
} 
not mention it in her autobiography. ${ }^{62}$ The two marriages she does mention in her autobiography are her two short lived marriages to white men. Winnemucca's humble Indian woman persona, with its accompanying deference to men and professed acknowledgement of their superior decision making skills, is clearly one Winnemucca adopted in order to gain acceptance from her readers and re-situate herself and Paiute Indian women in a relationship translatable to white societal constructs. Winnemucca's Paiute upbringing, independent travel and multiple marriages are evidence in her personal life of what some modern scholars call "gender," but that in fact inhabited a distinct Paiute context in which knowledge, age, and kinship were the dominant values. Her English language literacy helped shield and reshape what parts of her life, her powers, and her struggles were visible to readers in English.

\section{Moral Warrior Persona}

Finally, in her narrative, Winnemucca also takes on the persona of the moral warrior. This masculine persona acts outside the boundaries of white feminine conventions of submissive and pious behavior by emphasizing that in the given situation it would be morally wrong not to do so. When recounting an 1865 massacre of her people by whites - violence whites justified because of some missing cattle Winnemucca writes, "Oh, it is a fearful thing to tell, but it must be told. Yes, it must be

${ }^{62}$ Canfield, Sarah Winnemucca of the Northern Paiutes, 82. 
told by me. It was all old men, women and children that were killed..."63 Here it is Winnemucca's moral compass, not anger or spite, which demands that she must recount the atrocities done to her people by whites. It is an act of moral compulsion. When finding out that her brother might have been killed by Bannock Indians Winnemucca narrates,

Oh, when they told me this sad news about my dear brother, my heart was dead within me. A thousand thoughts passed through my mind. I said to myself, if my brother was killed by the Bannocks and we do go and be killed by them too! Then I told Captain Bernard the Indian men would not go for love or money. I told the captain I would go, if I had to go alone... there is nothing that will stop me. ${ }^{64}$

This description of sentimental and self-sacrificing behavior is highly associated with Victorian Christian womanhood; grieving for and remembering the dead was a central and extremely well-documented gendered labor during post-Civil War years. But Winnemucca goes beyond suffering to action. Winnemucca's warrior persona necessitates that she go into the Bannock camp with or without other Indian men or soldiers by her side. There is nothing that will stop her from going because her brother is possibly alive and in danger. Other men will not go, but Winnemucca must go on behalf of her brother. She is self-chosen and in this instance she becomes an Indian warrior. It is moral integrity, though, not manliness or bravery, that dictates she go.

${ }^{63}$ Hopkins, Life Among the Piutes, 77.

${ }^{64}$ Ibid., 153. 
In keeping with Winnemucca's moral warrior persona she was not afraid to publicize, on behalf of her people, the names of Indian agents and settlers, and provide proof of deceit whenever possible. ${ }^{65}$ Winnemucca used her weapons of language fluency and English literacy to reveal just how slanderous she could be to those who mistreated her and her people. In January of 1880 Winnemucca gained herself and her brother the audience of Carl Shurz, Secretary of the Interior appointed under Rutherford B. Hayes. Upon her arrival, in an interview with the press, she issued a veiled threat that "general and specific charges against the policy of the Indian bureau and the conduct of past and present agents (would) be made and sustained."66 During her meeting with the Secretary of the Interior, Schurz promised her everything she asked for. Winnemucca then related the following,

Secretary Shurz said to me, 'Sarah, so you are bound to lecture.' I said, 'People want me to.'

'I don't think it would be right for you to lecture here after the government has sent for you.... and paid your way here. The government is going to do right by your people now. Don't lecture now; go home and get your people on the reservation - get them located properly; and then, if you want to come back, write to us, and tell us you want to come back and lecture, and we will pay your way here and back again. ${ }^{67}$

Secretary Shurz certainly understood the damage Winnemucca could do with her skill in English and in an effort to get her to go home, promised that he would pay her way back

\footnotetext{
${ }^{65}$ This was a fairly acceptable practice among reform-minded white women who had little power over their own men. For example, white women reformers publicized the names of men who visited brothels in an effort to exert public pressure on their men's deviant behavior.

${ }^{66}$ Washington Post, January 20, 1880.

${ }^{67}$ Hopkins, Life Among the Piutes, 221.
} 
to lecture after her tribes' much needed supplies had arrived. He implored in vain;

Winnemucca lectured in D.C. anyway. Schurz became yet another exposed villain in Winnemucca's autobiography who contracted promises with the Paiutes he never kept, an indictment of the "rule of law" so vaunted in liberal theory of self-government. Winnemucca's moral warrior persona justified her fighting on behalf of her people in lecture halls, council tents, the White House and even in war. Her threats, aggression, and self-appointed warrior behaviors became palatable to her white readership because she posited them as necessary moral deeds that must be done on behalf of her people.

\section{Conclusion}

Written during the Era of Assimilation, a period of intense pressure on native people to abandon traditional lands, migratory patterns, and forms of family and tribal life, Sarah Winnemucca's autobiography Life Among the Piutes: Their Wrongs and Claims is a political text of oppositional conformity. Though she has been assessed by some of her own people as well as some scholars as promoting Euro-American assimilationist ideas of individualism and capitalism, Winnemucca's narrative actually opposes full assimilation, champions Paiute sovereignty, exposes white cruelty, and re-writes the predominant gendered, racial, political and cultural constructs that bound Native American identity. To veil her criticisms of assimilation, Winnemucca uses strategic Indian conformity and assimilated Indian personae to maintain audience reception while she simultaneously casts judgment on whites, resists Euro-American assimilative notions 
and counters stereotypical Indian identity. In the next chapter, her strategy of oppositional conformity will be placed in the context of the intense citizenship politics and pressures typical of the Reconstruction era, and the strengths and challenges of her approach will be evaluated. 


\section{CHAPTER TWO}

\section{OPPOSING COLONIALISM, REVISING CITIZENSHIP}

Life Among the Piutes expresses ideas that Winnemucca developed through lectures and letters to newspapers and Indian officials in the 1870s. In these earlier works, Winnemucca painstakingly strove to connect - and sometimes disconnect - a number of issues that commonly structured mainstream beliefs about Native Americans, colonialism, and citizenship. Winnemucca understood the highly gendered EuroAmerican attitudes of Indian extermination and how negative appraisals of Indian marriage, family life, and child-rearing justified a range of eliminatory strategies, including: homicide, removal, confinement, child abduction, cultural assimilation, and individual land legislation. She addressed these multiple Indian elimination strategies using two distinct arguments. First, Winnemucca argued against the eliminatory strategies of extermination, removal and confinement by telling the captivity tale of the Indian - rather than of wrongful captivity of whites by Indians. ${ }^{1}$ In particular, by inverting this dominant story - the Indian captivity narrative - Winnemucca re-wrote native peoples' identity from savage, untrustworthy "captors" of whites to reflect her lived reality: whites holding Indians hostage. By reconstructing the story of conquest Winnemucca cut away at Euro-American settlers' moral justifications for colonialism.

\footnotetext{
${ }^{1}$ Patrick Wolfe, "Land, Labor, and Difference: Elementary Structures of Race," American Historical Review 106, no. 3 (June 2001): 200-218.
} 
Second, Winnemucca argued against whites' eliminatory strategies of Indian assimilation or "citizenship" as defined predominantly by Eastern reformers. In her reflections on citizenship Winnemucca demonstrated a fluency in the discourse of rights that were so vital and contested during the Civil War, Reconstruction and Era of Assimilation. Yet, while Winnemucca used the same words as Eastern reformers to talk about citizenship, Winnemucca's definition of citizenship had a distinct and critical set of meanings. By articulating her own vision of citizenship Winnemucca found common ground with white middle-class reform audiences regarding normative rights, education and morality, but simultaneously challenged whites' foundational understandings of citizenship as including individualism and Christianity and strict "national" belonging. Indeed, her earliest preserved letters indicate her fluency in categories such as "civilization" and "savagery," emotionally charged labels that framed the social and moral expectations of whites concerning Native conversion to Christianity. Winnemucca's critique of “citizenship" for Indians neither fully adopted white assimilationist policies, nor did it insist on Paiutes' complete rejection of white "civilization.” Instead, Winnemucca's citizenship steered toward a third way for Paiutes and whites to co-exist in relative autonomy.

Winnemucca's proposed citizenship consisted of three main components. First, Winnemucca maintained that Paiutes should be able to own and control their own land and protect it from white encroachment as citizens; she saw the passage of the Dawes Act as one way for them to do this. Second, Winnemucca rejected the idea that Christianity 
was a fundamental requirement of "civilization" and pointed to Paiutes' long standing traditions of morality as the common ground that could unite Paiutes and white Christians as citizens. And third, Winnemucca championed English literacy and education for the Paiutes based on her personal witness of how vulnerable monolingual Indians could be. Her education plan differed from white reformers' plans, however, in that Winnemucca advocated education for the Indian taught by Indians. Winnemucca found fault with whites' insistence that “education” necessarily involved the removal of Indian children's identities as Indians. Winnemucca insisted that Indian children would be better educated if they were taught by literate Indians who knew and understood both languages and cultures.

\section{Opposing Colonialism: Critiques of "Civilization" and "Citizenship”}

Winnemucca's earliest preserved letter, written to Commissioner of Indian Affairs Ely Parker in 1870, sketches out some of her initial critiques and revisions of assimilationist and colonial pressure facing the Paiute. Written in defense of her people being forcibly removed from Camp McDermott, Nevada to the Truckee River Indian Reservation, the letter lays a foundation for her later revision of citizenship for her people. Winnemucca wrote,

if the Indians have any guarantee that they can secure a permanent home on their own native soil, and that our white neighbors can be kept from encroaching on our rights, after having a reasonable share of ground allotted to us as our own, and giving us the required advantages of 
learning, I warrant the savage (as he is called to-day) will be a thrifty and law-abiding member of the community fifteen or twenty years hence. ${ }^{2}$

Reassuring her readers that the Paiute could become a civilized member of society ("the required advantages of learning" and "the savage" becoming "thrifty and law-abiding") as well as painting the picture of permanency for Indians ("secure a permanent home"), Winnemucca's statement aligns to some degree with white ideals of Indian assimilation, and indeed uses the language of normative legal "rights." Member of the community is not exactly the same thing as exclusionary notions of citizenship in a nation state (i.e. The United States). Further, she insists that her people have a "permanent home" on "their own native soil," not just anywhere the United States Government might see fit to put them. There is also a demand that whites be kept from encroaching on Indian land. ${ }^{3}$ Championing the Paiute cause, Winnemucca understood Native Americans' need for white cooperation in order to maintain their lands. By aligning her rhetoric with themes common within Euro-American concepts of civilization, Winnemucca made a case for Indians' rights to their own land and for their ability to live without white encroachment on their lands. Her critical distance from the category "savage" ("as he is called today") nonetheless makes a space for some shared domain of "community" in which all

\footnotetext{
${ }^{2}$ Helen Hunt Jackson, A Century of Dishonor ([New York: Harper \& Brothers, 1881] Minneapolis: Ross and Haines, 1964), 396. Citations refer to the 1964 edition. ${ }^{3}$ Siobhan Senier, Voices of American Indian Assimilation and Resistance: Helen Hunt Jackson, Sarah Winnemucca, and Victoria Howard (Norman: University of Oklahoma Press, 2001), 75.
} 
members are equally responsible and "law-abiding." The letter was never answered by Commissioner Parker. ${ }^{4}$

Advancing this view of limited citizenship was extremely difficult for Winnemucca and other Indians because of the general climate of hostility and racism directed at Native people. In particular, as a woman, Winnemucca faced the sexualized and violent opposition to her physical presence, her ideas, and her right to represent her people. Indeed, Winnemucca spent much of her time deflecting whites' racism and justifications for violence against Indians. Winnemucca understood the highly gendered Euro-American stereotypes of the "hyper-sexual" and "savage" Indian and how these stereotypes justified whites' abhorrent treatment of Indians - namely the extermination strategies of Indian homicide, confinement and removal. She addressed these white extermination strategies by re-telling the captivity tale of the Indian in her narrative as well as repeatedly during the lectures she gave in the period of $1879-1884 .^{5}$ While testing these ideas Winnemucca built up cultural capital—audiences, media coverage, and a degree of notoriety-essential to launching a public voice. At the same time, her very publicness drew the negative fire she so keenly sought to deflect and redirect. Winnemucca's early messaging strategies represent an important effort in the direction of

\footnotetext{
${ }^{4}$ Although the letter was never answered by Commissioner Parker, Winnemucca was successful in getting her local newspaper to publish the letter, though she gained no redress from her local audience either. "An Indian Girl's Letter," Gold Hill Daily News (Gold Hill, NV), April 28, 1870. Eleven years later Helen Hunt Jackson would find this letter and reprint the letter in her watershed book, A Century of Dishonor.

${ }^{5}$ Wolfe, "Land, Labor, and Difference," 885. See also Gregory Wright, "(Re)Writing the Captivity Narrative: Sarah Winnemucca's Life Among the Piutes Records White Male Sexual Violence," Nevada Historical Society Quarterly 51, no. 3 (Fall 2008): 200-218.
} 
reform. By inverting the dominant white captivity narrative, Winnemucca re-wrote native peoples' trajectory of empowerment. More importantly, by reconstructing the story of conquest Winnemucca cut away at Euro-American settlers' moral justifications for colonialism -- that is, at their self-identification as deserving, accountable citizens of their government and dutiful Christians accountable to their God.

During her lectures, Winnemucca inverted white definitions of captivity and the entertainment captivity narratives of her time to show how her Indian tribe was held captive by whites. Speaking of the reservation system to one audience Winnemucca said, "When winter came we were unprovided for, and our children were shivering. That's the way your civilization treats my people."6 Later, to the white readers of her narrative she wrote even more bluntly of the captivity of the reservation system (touted as "protective" and "civilizing"), "For shame! For shame! You dare to cry out Liberty, when you hold us in places against our will, driving us from place to place as if we were beasts."7 Using white definitions of captivity and capitalizing on the popular captivity narratives of her day, Winnemucca's narrative, as well as her lectures, are full of descriptive acts of brutality and savagery by whites against her innocent tribe. ${ }^{8}$ As a

6 "Her Farewell Lecture," Daily Alta California (San Francisco, CA), 1879.

${ }^{7}$ Sarah Winnemucca Hopkins, Life Among the Piutes: Their Wrongs and Claims (Reno: University of Nevada Press, 1994), 244.

${ }^{8}$ In her book, White Captives, historian June Namias defines capture by Indians as viewed by whites in North America. She writes that whites viewed capture as "an act of brutality and savagery against an innocent, civilized, and superior foe.... a forced, prolonged imprisonment with the enemy... a separation from one's community, a loss of spouse and children, and a communion with or at least relentless exposure to representatives of the devil." June Namias, White Captives: Gender and Ethnicity on the American Frontier (Chapel Hill: University of North Carolina Press, 1993), 2. 
number of scholars have pointed out, the violent incidents Winnemucca relates in her narrative sound very much like white captivity accounts. ${ }^{9}$ She highlights the contradictions of "civilization" and "citizenship" and rewrites them as sexual license and moral corruption as practiced by whites. Winnemucca wrote,

These soldiers had gone...to Muddy Lake, where my people were then living and fishing, and doing nothing to any one. The soldiers rode up to their encampment and fired into it, and killed almost all the people that were there...It was all old men, women and children that were killed; for my father had all the young men with him...on a hunting excursion. After the soldiers had killed all but some little children and babies still tied up in their baskets, the soldiers took them also, and set the camp on fire and threw them into the flames to see them burn alive. I had one baby brother killed there. My sister jumped on father's best horse and ran away. As she ran the soldiers ran after her; but...my dear sister got away. This almost killed my poor papa. ${ }^{10}$

This incident shows an act of brutality and savagery against innocent Indians who were doing nothing more than living and fishing in their community. Much like white captivity narratives there is a senseless loss of life as white soldiers throw Indian children and babies onto the fire to watch them burn alive.

The thorny issue of land reform, land access, and ownership remained central to her arguments about Native survival and her middle ground of "citizenship," understood as mutually binding laws. Winnemucca described the reservation system as "forced,

\footnotetext{
${ }^{9}$ Wright, "(Re)Writing the Captivity Narrative," 200-218. Also see David T. Haberly, "Women and Indians: The Last of the Mohicans and the Captivity Tradition," American Quarterly 28, no. 4 (Autumn 1976): 432.

${ }^{10}$ Hopkins, Life Among the Piutes, 78.
} 
prolonged imprisonment," and "separation from community." Of her tribes' forced winter relocation from Camp Harney in Northern Nevada to the Yakama Indian reservation on the east side of the Cascade Mountains in southern Washington Winnemucca writes, "What! In this cold winter and in all this snow and my people have so many little children? Why, they will all die...the cruel, wicked, white people...are going to drive us to some foreign country, away from our own...my people have not done anything, why should they be sent away from their country?"11 This account also relates the loss of life her people, mainly women and children, suffered from the forced harsh winter travel. In Life Among the Piutes Winnemucca inverts the captivity narrative to show how Indians were held captive by whites, brutally murdered, separated from their community, lost their children, and endured prolonged imprisonment on unfamiliar reservations.

While during the nineteenth century captivity narratives eventually became everyday "escape literature" for the American public - exotic, foreign, and remote - they actually served a much larger purpose in the psyche of colonizing Euro-Americans, as Winnemucca well knew. Captivity narratives were filled with brutal Indian violence and made reciprocal violence on the part of Euro-Americans seem understandable and necessary; they justified Euro-American racism and the taking of Indian lands. ${ }^{12}$ When

\footnotetext{
${ }^{11}$ Ibid., 203-204.

${ }^{12}$ Haberly notes that early Puritan narratives of "captivity, suffering, and final redemption," were explained as part of God's plan and were published out of a sense of duty to God, but that "By the nineteenth century, that sort of easy metaphoric structure had disappeared; what remained, in its essence, was violence - the total and almost incomprehensible violence of captives scalped and beaten, women starved or tortured to death, babies drowned or bashed against blood-spattered
} 
we use a settler colonial framework to explain Euro-American western expansion it becomes apparent just how important captivity narratives were in propelling and defending the settler colonist mission. Winnemucca's inversion of the captivity narrative on behalf of Indian people thus becomes politically significant. By speaking in front of audiences, writing letters to newspapers, and granting interviews with reporters Winnemucca used the popular mass entertainment mode of Indian "storytelling" among whites to tell a highly politicized story of white brutality. The roles her characters fill are familiar to her audience - except the protagonists are Indian and the antagonists white. In Winnemucca's inverted captivity narrative whites are just as brutal as are Indians in the mass entertainment captivity narratives, especially as dramatized in the "wild west" shows of the 1880 s and the dime novels so popular in her time period. ${ }^{13}$ While mass entertainment narratives fueled the stereotypes that justified white brutality against Indians, Winnemucca's engagement in public and in print offered resistance, and at times even justified violent Indian retaliation.

rocks, children with faces burned into unrecognizable scars." (432). Castiglia further describes captivity narratives thus: "Asserting that innately bestial Indians were incapable of cultivating land, let alone cultures, captivity narratives seem[ed] to suggest that whites need not feel guilty over the extermination of Indians and the appropriation of their land." Haberly, "Women and Indians," 432. Christopher Castiglia, Bound and Determined: Captivity, Culture-Crossing, and White Womanhood from Mary Rowlandson to Patty Hearst (Chicago: University of Chicago Press, 1996), 2.

${ }^{13}$ Whether firsthand accounts or fictionalized novels, captivity narratives were popular in America for over a hundred years; from 1750 to 1850, the Indian captivity narrative was one of the chief staples of popular literary culture. (Haberly) Castiglia asserts that the captivity narratives "offered sensational stories of explicit or implied sex and violence... [and] represent a pioneering example of the prurient appeal of mass entertainment." He also asserts that captivity narratives, or so called "penny dreadfuls" were often invented by authors eager to make money, as they sold extremely well. Haberly, "Women and Indians," 431-33. Castiglia, Bound and Determined, 2. 
Winnemucca's writings also show that she keenly understood the economic underpinnings of white brutality. More succinctly stated, Winnemucca knew that white settlers wanted Indian land and, to many whites, this meant Indian extermination. ${ }^{14}$ While Winnemucca might not have called whites "settler colonists," historian Patrick Wolfe's recent definition of settler colonialism provides a powerful framework for explaining how Euro-American ideological roots explained and even necessitated Native extermination. Wolfe defines settler colonialism as a type of colonialism in which “... the colonizers come to stay, expropriating the native owners of the soil...the primary logic of settler colonialism can be characterized as one of elimination." 15 Winnemucca understood how native stereotypes, propelled by captivity narratives, justified the settler colonial mission of extermination. Indeed part of the reason why Winnemucca promoted a middle ground "citizenship" with whites is because she knew white settlers had come to stay and she was seeking grounds for Paiute survival. During one of her first lectures at

\footnotetext{
${ }^{14}$ For a report of Winnemucca's lived reality of settlers' land-hungry attitudes toward Paiutes and other tribes in the Great Basin Region, see "Gen. Crook on the Bannock War," New York Times, June 23, 1878. See also General Sheridan's words quoted in: Dee Brown, Bury My Heart at Wounded Knee: An Indian History of the American West (New York: Henry Holt, 1970), 170.

${ }^{15}$ Wolfe further clarifies his theory by adding the following footnote: "Hence 'pure' settler colonialism of the Australian or North American variety should be distinguished from so-called colonial settler societies that depended on indigenous labor (for example, European farm economies in southern Africa or plantation economies in South Asia)." (885) Settler colonists came with cultural notions of agriculture (over hunting and gathering) as the more civilized and efficient use of land. Wolfe writes, "The key concept is that of private property. In distinctively Lockean fashion, the doctrine held that property in land resulted from the mixing of one's labor with it to render it a more efficient provider of wealth than it would have been if left in its natural state." (869) At a very basic level, from the Euro-American point of view, Indians were not using the land efficiently. American Indians, it seemed to Euro-Americans, simply roamed the land at will gleaning sustenance as needed. Thus, from the Euro-American point of view, Indians not only had no real connection to the land but their survival methods were wasteful and archaic. Wolfe, "Land, Labor, and Difference," 868-69, 885.
} 
Platt Hall in San Francisco, Winnemucca reminded her audience that if one Indian committed a crime against a white person, whites sought to "exterminate" all Indians. Indicating a climate of terror and lawlessness, Winnemucca pointed out that no distinction was made between the Indians who committed the crimes and those who did not. In 1879, the Daily Alta California newspaper recorded Winnemucca as follows,

The Chinese, said she, sometimes do fearful things, and commit horrible murders, but you search for those men for two or three years until you catch them, and when they are caught you punish them. You don't attack all the Chinese who are with you. No you let them live with you. You take all the natives of the earth to your bosom but the poor Indian, who is born of the soil of your land and who has lived for generations on the lands which the good God has given to them, and you say he must be exterminated. ${ }^{16}$

In the above quote Winnemucca distinguishes the disparate treatment by the hegemon of two "similar" groups. Though Winnemucca exaggerates whites' benevolent treatment of the Chinese she asserts that the Chinese were "other" and possibly "heathen" but still garnered some legal niceties from the colonizer Indians were treated differently from the Chinese, who were not indiscriminately killed when one Chinese person committed a crime. Second, she subtly reasserts Indians' claim to the lands they lived on by describing them as land that "the good God (had) given them." Here Winnemucca distinguishes the Chinese from the Indians by underscoring native rights to land. ${ }^{17}$ Her

\footnotetext{
16 "The Indian Question," Daily Alta California (San Francisco, CA), December 4, 1879.

${ }^{17}$ As early as the colonial days of America and the American Revolution whites ceded Indians' claim to the land by remunerating Indians for the lands Indians originally inhabited but that whites wanted. Speaking of the newly formed American federal government Prucha writes, "The one basic requirement of the new government that never faded from the consciousness of its
} 
overarching message, however, drew attention to the reality that whites, because of their desires for land, killed Indians indiscriminately and violated their own republican principles concerning the "rule of law" and legitimate "self-government."

Winnemucca also recorded numerous examples of whites' complete disregard for Indian life. ${ }^{18}$ Her narrative reports a violent incident between whites and Paiutes in the spring of 1865 . When the Paiutes learned that one of their men, though innocent, was shot and killed by a white man, a few members of the tribe resolved to exact revenge on the killer. The story Winnemucca relates regarding this incident can certainly be interpreted as one in which Winnemucca highlights Paiute understandings of agreed-upon rules of war and justice. However, I argue that Winnemucca also uses this story to underscore the "savagery" of whites and the "civilization" of Indians by emphasizing the reality that if Paiutes killed a white man whites would indiscriminately kill innocent Paiutes. When Winnemucca and her brother heard of their tribesmen's plans for revenge they were extremely nervous and eventually persuaded the remainder of the Paiute tribe to find and kill the Paiute men who were planning to kill the white murderer. Winnemucca's brother reminded the Paiutes that many whites wanted the Indians dead

leaders was peace on the frontier. The government needed peace in which to get firmly established, and it had to tailor its practice to this great end. Knox came to realize that agreements with the Indians based upon the right of conquest did not work and that adherence to such a policy would continually endanger the peace on the frontier. The British and colonial practice of purchasing the right of the soil from the Indians was the only method to which the Indians would peaceably agree...He recommended, therefore, that the land ceded by the...Indians be compensated for and that future cessions be acquired by purchase." Francis Paul Prucha, The Great Father: The United States Government and the American Indians, vol. 1 (Lincoln: University of Nebraska Press, 1984), 49.

${ }^{18}$ For more on this subject see Prucha, "Chapter 21: Military Challenge," in Great Father, 545. 
and would kill all the Paiutes if a single white man was murdered by an Indian.

According to Winnemucca's narrative her brother told his people to "kill [the Paiute men seeking revenge] if you can; by so doing we will save ourselves, for you know if we allowed our people to kill the white men we should all be killed here. It is better that we should kill some of our own men than to be all killed here."19 In this statement Winnemucca's brother asserts an already understood notion of white disregard for Indian life. He reminds the Paiutes that if they killed one white man, the whites would kill them all without investigation or pretense of individual blame. Winnemucca's narrative and her public appearances show that she understood how stereotypical Indian identity justified the settler colonial mission of living on Indian land, and that she pressed the case for Indians as human, deserving, and wrongly victimized residents of the continent. By rewriting Indian identity using the popular captivity narrative framework, Winnemucca undermined whites' cultural justification for Indian brutality and extermination.

Of the white social categories scrutinized by Winnemucca, "citizen" and "Christian" receive the most damning appraisals. To the readers of her narrative she writes, “...Christian people, how long are you going to stand by and see us suffer at your hands?"20 Speaking of white volunteers who were supposed to be helping the army alongside Winnemucca during a battle in the Bannock War of 1878 Winnemucca cuttingly writes, "Where do you think the citizen volunteer scouts were during the fight? The citizens, who are always for exterminating my people...had all fallen to the rear,

\footnotetext{
${ }^{19}$ Hopkins, Life Among the Piutes, 80.

${ }^{20}$ Ibid., 89.
} 
picking up horses and other things which were left on the battle-field..."21 Winnemucca juxtaposes her assistance in the war with the "citizens" who selfishly avoid the fighting and instead seek spoils in the conflict's aftermath. In contrast to the criticized white social categories of "citizen" and "Christian," Winnemucca makes a space of accommodation for the acceptance of a category of whites she calls "soldier-fathers." "Solider-father" was the label she applied to military men stationed with or near the Paiute. Paiutes sometimes obtained redress from local military authority when their agents were abusing them on the reservations. Though the "soldier-fathers" Winnemucca knew never remedied the problem of the corrupt Indian agents they often issued the Paiutes cast off clothing and food in an effort to keep peace on the frontier. It was "solider-fathers" Winnemucca knew best and trusted most. Of "soldier-fathers" Winnemucca wrote, "There were no Custers among the officers in Nevada...Is there not good reason for wishing the army to have the care of the Indians, instead of the Indian Commissioner and his men? The army has no temptation to make money out of them, and the Indians understand law and discipline as the army has them; but there is no law with agents." 22 For Winnemucca, the "Christians" were supposedly accountable to a foreign god and the "citizens" were supposedly accountable to a foreign power - and in her experience neither power wielded much influence over its subordinates. But Winnemucca knew that "soldier-fathers" were accountable to their commanders and had seen them punished for disobeying orders.

\footnotetext{
${ }^{21}$ Ibid., 177.

${ }^{22}$ Ibid., 178.
} 
Winnemucca's positive perception of military men was further fostered by her friendship with General Oliver Otis Howard. Her assistance to him during the Bannock War of 1878 proved invaluable to him and the two kept in touch via letters through the end of Winnemucca's life. Often, when Winnemucca did not receive payment from reservation agents for her translation services she would write General Howard and his intervention on her behalf usually produced results. Her faith in "soldier-fathers" is evident in a letter she wrote General Howard asking for payment she never received from the government for her service in the Bannock War. Wrote Winnemucca, "Dearest Friend...I think by your and Lieutenant's...help the government can do something for me...I know there is no one else to help me...for you know what work I did for the government (during) the Bannock War...I have not heard anything from the money I was to get..."23 In another effort to receive money she had not been paid for her services as an interpreter and teacher at Vancouver Barracks in 1881 Winnemucca again appealed to her "soldier-father," General Howard. She wrote, "Dear Friend...I once more beg of your help. General I did my duty faithfully while I was at Vancouver teaching... you and your fellow officers can talk for me, I know if you will the government would help me..."24 Most of the time Winnemucca appealed to General Howard to intervene on her behalf he did and she was able to get the help she needed. Her experience may not have been so positive if her truest "soldier-father" ally had not been a leading General in the

\footnotetext{
${ }^{23}$ Letter from Winnemucca to General O. O. Howard, December 28, 1880. Sarah Winnemucca Hopkins to General Oliver Otis Howard. Oliver Otis Howard Papers, 1833-1912. The George J. Mitchell Department of Special Collection and Archives, Bowdoin College Library.

${ }^{24}$ Ibid., July 20, 1881.
} 
U.S. Army at the time. But the fact that, in Paiute experience, the army served as an ally that helped Paiute tribes when they were in desperate need of food and clothing, cannot be overlooked. This category of acceptance Winnemucca made for "soldier-fathers," however, later set her at odds with Eastern reformers - her recognition and touting of military aid was met with disdain by Eastern reformers whose agendas called for the elimination of military control over the Indians.

Winnemucca's pragmatic suggestion that the military take control of the reservations in place of the Commission of Indian Affairs was in opposition to Eastern reformers who wanted reservation control removed from the military and placed with civilians and missionaries. Absent this difference Winnemucca might have been able to better connect with reform-minded women interested in the so-called Indian problem in her time period. As a woman, Winnemucca could have appealed to the dominant gendered dimensions of female solidarity. Her narrative however, suggests the barriers to female solidarity Winnemucca came up against when resisting colonialism. As Margaret Jacobs suggests, historians need to "consider the identities of white, middle-class women in the West not just as gendered beings but as racialized and national subjects who were part of a settler colonial project and formed their identities in relation and opposition to indigenous people, Mexican settlers, and immigrant populations." ${ }^{25}$ When considering these identities, it becomes clear why many white women as well as men readily applied depreciatory stereotypes to Indians. In her narrative Winnemucca contrasts the harsh

${ }^{25}$ Margaret Jacobs, “Getting Out of a Rut: Decolonizing Western Women's History,” Pacific Historical Review 79, no. 4 (November 2010): 594. 
reality of her life experience against the ideal of female solidarity. She relates an experience she had in a restaurant while dining with a Lieutenant Wilkinson during the Bannock War; her words bolster Jacobs's argument that white middle-class women were nationalized people who formed their identities in relation and opposition to indigenous people. When a white waitress arrives at a table Winnemucca is sitting at with one of the “soldier-fathers," Lieutenant Wilkinson, this white woman asks him: "Why don't you take her (Winnemucca) and tie one part of her to a horse, and the other part of her to another horse, and let them go? I would see the horses pull her to pieces with good grace...Rope is too good to hang her with." 26 Winnemucca sums up the waitress incident with these words: "Dear reader, this is the kind of white women that are in the West. They are always ready to condemn me."27 Winnemucca's understatement actually heightens the gendered harshness of this story. Winnemucca's ability to construct a common ground of womanhood in her discussions was limited, and as we shall see, worked only briefly and unevenly during her time in Boston, 1882-83. The narrative gives very little space to such common ground. Life Among the Piutes emphasizes colonizing women as "another enemy of (Winnemucca's) that was unlooked for."28

In each venue she engaged with, Winnemucca made painstaking efforts to establish a gendered terrain of colonial violence and by so doing, establish an appropriately feminine domain of resistance. By reconstructing the captivity tale of the

\footnotetext{
${ }^{26}$ Hopkins, Life Among the Piutes, 168.

${ }^{27}$ Ibid.

${ }^{28}$ Ibid.
} 
Indian, Winnemucca re-identified Indians from "savages" to innocent hostages and eroded whites' moral justifications for Indian extermination, confinement and removal. In her narrative Winnemucca does not even receive the gendered courtesy and sympathy due a respectable woman in the dominant society. Using an inverted captivity narrative Winnemucca spoke to her audiences via a framework they were familiar with, and inclusively gendered her message by extending the "savage" stereotype to the white woman in the West.

\section{Taking Citizenship East}

As suggested above, Winnemucca's narrative conveys an understanding of the gendered dimensions of colonialism and the gendered ground for potential resistance to it. The first Indian reform agencies to spring up after the Civil War and Reconstruction in sympathetic response to the unfair treatment of Indians by government, military and Indian agents originated in Boston and Philadelphia. These organizations were largely populated by Protestant women, well-versed in anti-slavery and temperance ideas. These organizations drove the national Indian agenda for the last two decades of the nineteenth century, a central and animating feature of which was "woman's work for woman," that is: protecting and 'uplifting' women to their proper domestic and maternal sphere, "up" from "primitive, heathen" conditions. ${ }^{29}$ Eastern Christian reform groups solidly pushed Indian assimilation legislation through Congress during Winnemucca's time.

${ }^{29}$ Prucha, Great Father, 611-612. 
"Convinced of the superiority of the Christian civilization they enjoyed, they were determined to...turn the individual Indian into a patriotic American citizen," notes Frances Prucha. "Eastern philanthropists and humanitarians, chiefly from Boston and Philadelphia, led the fight." 30

The Civil War and Reconstruction placed citizenship near the center of the Indian question. ${ }^{31}$ A string of publicized wrongs against Indians during the late 1870 s and early 1880s began with the Ponca Indian Affair—which resolved in a form of limited citizenship rights for chief Standing Bear--and coincided with the publication of Helen Hunt Jackson's A Century of Dishonor, published in 1881. As new research in government archives suggests at least some Native women pressed for formal, federal citizenship rights in the $1870 \mathrm{~s}^{32}$ These changes suggest new found fervor and opportunity in Indian reform, and a mixed, dynamic vocabulary for proposing change.

Though Winnemucca does not detail how exactly she learned about East Coast Indian reform in her writings, the groups that pressed for change were expert at making

\footnotetext{
${ }^{30}$ Ibid., 609-611.

${ }^{31}$ As Christine Bolt notes, the Indian question was put on hold during the Civil War for most Eastern reformers. She writes, "War years are not usually good years for reform groups. The pressure is on them to lay aside their campaigns, take up war work instead and generally foster national unity. They may hope to be remembered for good behavior when hostilities end, but they are just as likely to find a public grown tired of the old crusades and a government grown anxious for retrenchment. The temperance and women's movements were both disrupted by the Civil War and the conflict followed a depression which had already had an adverse effect upon reformer efforts, especially in the North. Indian people were particularly unlikely to be viewed sympathetically by whites during a war which saw the southern tribes giving assistance to the Confederacy...." Christine Bolt, American Indian Policy and American Reform: Case Studies of the Campaign to Assimilate the American Indians (London: Allen and Unwin, 1987), 71.

${ }^{32}$ Linda M. Waggoner, "Adopting the Habits of Civilization: The Ho-Chunk Women Who Chose American Citizenship in 1870," (unpublished paper in author's possession cited with permission, 2012).
} 
themselves heard in media, philanthropic, and, of course, church networks. The first post-Reconstruction organization devoted to "helping" the Indians escape the unfair treatment thrust upon them by government was the Boston Indian Citizenship Committee, a committee of five prominent philanthropic, Christian, merchant men from Boston. ${ }^{33}$ Initially they were appointed to investigate the wrongs done to the Ponca Indians in 1878. ${ }^{34}$ The Boston Indian Citizenship Committee proved pivotal to helping the Ponca Tribe gain monetary redress from the federal government for forcibly removing them to Indian Territory from their previously granted reservation on the Missouri. The spring of 1879 also witnessed the informal beginnings of what would officially become the Women's National Indian Association in Philadelphia in 1883, founded by Mary Bonney and Amelia Quinton of the Women's Home Mission Society of the First Baptist Church

\footnotetext{
${ }^{33}$ Prucha, Great Father, 611.

${ }^{34}$ The Ponca Affair served as the catalyst that renewed Eastern reformers sentiment for the Indian cause. The Ponca were a peaceful Siouan tribe who had been granted a reservation along the Missouri. Three years after their reservation had been granted the U.S. reappropriated their land to the Sioux - the Poncas' enemies. To remedy the problem the government decided not to return the land to the Poncas, but rather to remove them to Indian Territory. The chief of the Poncas, Chief Standing Bear, and some of his people decided to return north. With the help of prominent lawyers in Omaha, Nebraska, on April $30^{\text {th }}, 1878$, Chief Standing Bear and his people won the court case Standing Bear v. Crook, when Judge Elmer S. Dundy of the United States District Court ruled that "an Indian is a 'person' within the meaning of the laws of the United States, and has, therefore, the right to sue out a writ of habeas corpus in a federal court." (568) Chief Standing Bear and Suzette LaFlesche, an Omaha Indian girl later known as "Bright Eyes," then appeared in several Eastern cities to relate the wrongs of the Poncas. The Boston Indian Citizenship Committee's investigation into the Ponca case revealed their position that the federal government should be held responsible. This committee helped the Ponca secure one-hundredsixty-five thousand dollars of funding via Congress on March 3,1880, "to indemnify the Ponca tribe of Indians for losses sustained by them in consequence of their removal to the Indian Territory, to secure to them land in severalty on either the old or new reservation, in accordance with their wishes, and to settle all matters of difference with these Indians." (571) The Boston Indian Citizenship Committee was the committee that proved pivotal in helping Chief Standing Bear gain this monetary redress from the federal government. See Prucha, Great Father, 566, 568, 570-571. For more on the Ponca Indian Removal, see Prucha's chapter, "Reservation Policy," in Great Father.
} 
of Philadelphia. And in December of 1882 Henry Pancoast and Herbert Welsch formed the Indian Rights Association in Philadelphia. The Indian Rights Association emphasized passing legislation on behalf of the Indian. Together these three groups formed the nuclei of Indian reform groups in the East. They cooperated effectively and shared the same goals for the Indians. Collectively, they petitioned Congress to (a) fulfill and maintain their treaties with the Indians, (b) build schools on every reservation for the purposes of educational and industrial training, (c) allot land in severalty to Indians who wanted it, and (d) grant Indians full rights under the law. ${ }^{35}$

These three organizations - the Women's National Indian Association, the Indian Rights Association, and the Boston Indian Citizenship Committee - branded themselves as Christian organizations and relied on churches throughout the country for both monetary and nation-wide branch support. Particularly the Women's National Indian Association adopted missionary work among the American Indians as their primary endeavor. At the end of their third year the WNIA had opened eleven missionary stations and were, "indirectly aiding several other tribes." ${ }^{\text {36 }}$ At their fourth annual meeting Mary Bonney, president of the WNIA, "included the elevation of both Indian women and their homes as one of the main objectives of the organization," and told the attendees that the "work would continue until 'the Indian women and home are permitted to rise from

\footnotetext{
${ }^{35}$ For more on these organizations see Prucha's chapter, "The New Christian Reformers" in American Indian Policy in Crisis. Francis Paul Prucha, American Indian Policy in Crisis: Christian Reformers and the Indian, 1865-1900 (Norman: University of Oklahoma Press, 1964). ${ }^{36}$ V.S. Mathes, "Nineteenth Century Indian Women and Reform: The Women's National Indian Association," American Indian Quarterly 14, no. 1 (Winter 1990): 7.
} 
pagan darkness, degradation, destitution and suffering into the light of Christian faith, nobleness, comfort and independence...,"37 By 1886 the Women's National Indian Association had secured eighty three branches across the nation and their funding was rising rapidly. ${ }^{38}$

Eastern reform groups' success lay in their representation of the evangelical American zeal of the nineteenth century. ${ }^{39}$ Indians' adoption of Christianity was foundational to Eastern reform definitions of "civilization." To Eastern reformers, to be civilized meant that one was Christian and the concept of individuality was directly linked to Christianity. Prucha explains, "The distinguishing work of American evangelicalism was its insistence on individual salvation. The concern was for the conversion and reformation of individuals as the means of correcting evils or wrongs in society."40 Merrill Gate, President of Rutgers College and member of the Board of the Indian Commissioners, summed up Christian reformers' sentiments when he said, "But if civilization, education and Christianity are to do their work, they must get at the individual...The sad uniformity of savage tribal life must be broken up! Individuality must be cultivated. Personality must be developed. And personality is strengthened only by the direction of one's own life through voluntary obedience to recognized moral

\footnotetext{
${ }^{37}$ Ibid.

${ }^{38}$ The Women's National Indian Association Funding rose from $\$ 3,880$ in 1885 to $\$ 16,500$ in 1890. See Prucha, Indian Policy in Crisis, 137.

${ }^{39}$ Prucha notes, "the story of American Evangelicalism is 'the story of America itself in the years 1800 to 1900, for it was Evangelical religion which made Americans the most religious people in the world, molded them into a unified, pietistic-perfectionist nation, and spurred them on to those heights of social reform, missionary endeavor, and imperialist expansionism which constitute the moving forces of our history in that century." Prucha, Indian Policy in Crisis, 151.

${ }^{40}$ Ibid., 152.
} 
law."41 In other words, to be civilized one must be concerned with his or her own standing before God, and because evangelical Christians believed in individual salvation, Indians needed to have an individual, not communal worldview. To reformers this meant a breakdown of the communalistic family living traditions of the Indians. As long as Indians identified themselves as members of large familial groups, rather than the nuclear family units Christians valued, reformers argued they could not attain the necessary selfinterest required for eternal salvation. As numerous scholars of both reform movements and imperialism have emphasized, colonialism was understood in gendered terms with particular impacts on women and family life.

\section{Middle Ground Citizenship, Gender, and Paiute Sovereignty}

The main vehicle for Winnemucca to approach the gendered dimensions of Indian reform was through moral discourse involving ethics and the treatment of women and children. An important dimension of this tactic occurs in Winnemucca's autobiography, especially around religious conversion. The white and Paiute characters in Winnemucca's narrative and in her lectures, particularly the Paiute women, swap identities. In almost every story she tells, the "civilized white man" acts the role of the "savage Indian" and the Paiute Indian, in most cases a vulnerable and unprotected Paiute Indian woman, represents humanity and goodness. Because the nineteenth century Victorian gender system privileged wives and mothers as moral superiors to men, the prevailing ideal was that it

${ }^{41}$ Ibid., 153. 
was woman's job to "civilize" man. By making the Paiute woman the "civilizer" of the white man Winnemucca mobilized notions of Victorian womanhood while making a gendered political statement about Indian women. By aligning Indian women with white Christian women as the "civilizers" of white men, Winnemucca made a political statement about the equality of Indian and white women's moral authority. As the "civilizer" of white men, Winnemucca identified Indian women as moral beings who, like their white women counterparts, maintained and cultivated humanity and goodness among the human race. By doing so Winnemucca advocated a citizenship characterized by a shared morality - rather than a uniform religion - in which Paiute behavioral norms complimented rather than undermined prominent tenets of Christianity.

Importantly, unlike her Indian predecessors' autobiographies, Son of the Forest: The Experience of William Apes, a Native of the Forest (1829), and The Life, History, and Travels of Kah-ge-ga-gah-bowh (George Copway) (1847), Winnemucca's autobiography is not a conversion tale that leads Winnemucca from "heathenism" to Christianity. Lacking the central spiritual journey themes prevalent in Apes's and Copway's works, Winnemucca does not tell a personal tale of spiritual confession, Christianity or missionary work. Winnemucca's tale, therefore, cannot be considered a conversion tale, and her personal resistance to Christianity was a sticking point for Protestant women in the East. Nor can Winnemucca's narrative be considered an anticonversion tale. Rather, Winnemucca's political narrative of oppositional conformity is aimed at re-situating Paiute Indians in proximity to the constructs of white civilization, in 
but not of the United States. In order to show that Paiutes are not "heathens",

Winnemucca makes room for traditional Paiute ways of life by pointing to her peoples' long accepted and long practiced tenets of ethics and fairness, if not exactly Christianity per se. By pointing to the Paiutes' moral customs Winnemucca makes a political statement of oppositional conformity - Paiutes don't need to fully adopt Christianity with its constructs of individuality in order to be good people. While she does not outright say that Paiutes are Christian, she makes a strong case for Paiute ascription to the Christian values. She does this masterfully by juxtaposing white cruelty with Paiute humaneness. Winnemucca writes,

He (the agent) beat an Indian man almost to death for no cause whatever. He asked him to help him carry a sick woman. The Indian was a little too long getting on his moccasins. The agent knocked him down with a stick, and beat him so shamefully I ran to him and caught hold of him saying, 'Do not beat him so.' The man rose up, and as he did so, the agent raised the stick again to him. At this the Indian took hold of it; then the agent took out a pistol to shoot him; but white men came to him and said, 'Do not shoot him.'... he (our agent) was a Christian man. ${ }^{42}$

When again this same agent beat and then threatened to kill an Indian boy for laughing at him, the agent is rebuked by Winnemucca's brother, who says, "Why talk of killing?...Of course, that is the kind of men that are called good, - men who talk to the Spirit Father three times a day, but who will kill us off as they would kill wild beasts."43 In this passage the "savage" is the Christian white man who relentlessly beats and kills Indians as he would wild beasts, and Winnemucca, the Indian woman, is the civilizing and

${ }^{42}$ Hopkins, Life Among the Piutes, 133.

${ }^{43}$ Ibid., 132. 
humane influence pleading with the "savage" to stop. By showing her and her brother's moral ascription to Christian values Winnemucca makes a case for Paiute citizenship based on a shared morality, thereby sidestepping the hotbed political issues of Indian racial inferiority and Indians' rejection of individualism and placing Paiutes on the same moral ground as all Christians.

Winnemucca challenged that religious conversion was the only or main pathway to national citizenship, highlighting Paiute tradition as morally equivalent and complimentary to Christianity. Each time Winnemucca describes injustice toward her people she points to the white offender's professed Christianity. Then, just as readily, Winnemucca highlights her own people's long standing traditions of humaneness as taught to them by their fathers. In the following passage Winnemucca refers to the Golden Rule and shows that Paiute children are taught to treat others as they would want to be treated. Winnemucca relates the teaching of Paiute children in the following passage

...the whites have not waited to find out how good the Indians were, and what ideas they had of God, just like those of Jesus, who called him Father, just as my people do, and told them to do to others as they would be done by him just as my people teach their children to do. My people teach their children never to make fun of any one, no matter how they look...Be kind to all, both poor and rich, and feed all that come to your wigwam, and your name can be spoken of by every one far and near...This is the way my people teach their children. It was handed down from father to son for many generations. I have never in my life saw our children rude as I have seen white children and grown people in the streets. ${ }^{44}$

\footnotetext{
${ }^{44}$ Ibid., 51.
} 
This passage richly criticizes whites for not practicing their own professed Christian values and establishes Paiutes' religious equivalency. First, Winnemucca ascertains that Paiutes, like whites, believe in God. Second, Paiutes teach the Golden Rule: “(Jesus) told them to do to others as they would be done by him just as my people teach their children to do." Paiute children are not racist: "My people teach their children never to make fun of anyone no matter how they look." And Paiute children do not let people starve in their presence: "Be kind to all, both poor and rich, and feed all that come into your wigwam." Third, and perhaps most damning, Paiutes practice the Golden Rule: "I have never in my life saw our children rude as I have seen white children and grown people in the streets." Paiutes suffer many wrongs at the hands of whites while in Winnemucca's narrative Paiutes remain innocent and moral. As inherently moral people Paiutes are taken out of their savagery and put inside the realm of nineteenth century civilization constructs, without needing Christianity to do so. Indeed, in her narrative, and during some of her speaking engagements Winnemucca goes as far as to claim that Paiutes' morality eclipsed Christianity. Winnemucca writes, "We don't need to be taught to love our fathers and mothers. We love them without being told so." ${ }^{45}$ Here Winnemucca referred rather sarcastically to one of the Ten Commandments to "Honor thy Father and Mother."

\section{Native Women's Role in English Language Literacy and Translation}

\footnotetext{
${ }^{45}$ Ibid., 45.
} 
The importance of Protestant women in advancing English literacy through Reconstruction, Home Missions, Sabbath School training, public education, and temperance work in the late nineteenth century can scarcely be overstated.

Though the details of Winnemucca's learning are obscured from the historical record, literacy played an important role in Winnemucca's life from the time she was a young child and she advocated English literacy among her people as early as $1870 .{ }^{46}$ Indeed, her writings repeatedly emphasize the power of knowing and the dangers of not knowing English among the Paiute, and the important related generational, gender, and cultural issues. These issues impacted the Winnemucca family quite personally and profoundly. In 1846 Winnemucca's grandfather, Chief Truckee, served as a scout for John C. Frémont during the Bear Flag Revolt. During his service with Frémont, Chief Truckee grew to understand the power of the written word. When he returned to his tribe he brought with him a letter from Frémont stating that all who read it should treat him well. ${ }^{47}$ Truckee prized this letter above everything else and called it his "rag friend."

Winnemucca recorded Truckee's explanation of his rag friend's power once he returned from his travels with Frémont's group. Winnemucca writes, "He then showed us a more wonderful thing than all the others that he had brought. It was a paper, which he said could talk to him. He took it out and he would talk to it, and talk with it. He said, 'This can talk to all our white brothers, and our white

\footnotetext{
46 "An Indian Princess in the Sage Brush," Daily Alta California (San Francisco, CA), August 29, 1870.

${ }^{47}$ Sally Zanjani, Sarah Winnemucca (Lincoln: University of Nebraska Press, 2001), 23.
} 
sisters, and their children.' He also said the paper can travel like the wind, and it can go and talk with (whites') fathers and brothers and sisters, and come back to tell what they are doing, and whether they are well or sick."48

During the early days of episodic white/Paiute contact, Winnemucca's grandfather would simply show whites his letter and the Paiutes would be treated well. Grandfather Truckee interpreted his "rag friend" in terms of native world views; a slightly magical, alive, and potent force that literally lived within his family and tribe. As a kind of "friend" or family treasure, it could be shared, inherited, and circulated to mark new bounds of power and authority, within traditional parameters. He displayed it to whites and to his tribal community, often effectively and dramatically. ${ }^{49}$ From a very young age Winnemucca understood the power whites placed on the written word. She saw her grandfather's rag friend communicate with whites and on more than one occasion watched it provide him gifts and food from whites. ${ }^{50}$

\footnotetext{
${ }^{48}$ Hopkins, Life Among the Piutes, 18-19.

${ }^{49}$ Ibid., 26.

${ }^{50}$ Winnemucca recorded one such incident that occurred in 1851 , when Truckee insisted that in order to learn white ways, he and some of his family journey to the San Joaquin Valley in California to work for whites for the summer. While traveling through the Great Basin Territory to the San Joaquin Valley the Paiutes passed a wagon train. Winnemucca recorded her grandfather to have announced he was going to show them his rag friend. She writes, "As he rode up to one of their tents, three white men came out to him; then they took him to a large tent. Quite a number of white men came out to him. I saw him take out the paper he called his rag friend and give it to one of the men who stood looking at it; then he looked up and came toward him and held out his hand to my grandfather, and then the rest of the white men did the same all around. Then the little children and women did the same." Ibid., 43.
} 
Truckee strongly advocated peace between Paiutes and whites as well as Paiute literacy. Winnemucca revered her grandfather and she was his favorite grandchild. Though he died when Winnemucca was a young girl, Truckee's peace policy and advocacy of Paiute literacy were creeds that Winnemucca internalized and promoted for the rest of her life. Having understood the power of whites' written language it was Truckee's dying wish that Winnemucca and her sister be taken to California to learn English. On his deathbed he instructed a white friend, "You see there are my two little girls... They are my sons' children, and the two little girls I want you to take to California, to Mr. Bonsal and Mr. Scott. They will send them to school to 'the sisters,' at San José. Tell them this is my last request to them. I shall soon die. I shall never see them in person, they have promised to teach my two little girls when they become large enough."51 Winnemucca revered her grandfather and she titled chapter four of her book, “Captain Truckee's Death.” Of his death she writes, "I felt the world growing cold; everything seemed dark. The great light had gone out. I had father, mother, brothers, and sisters; it seemed I would rather lose all of them than my poor grandpa. I was only a simple child, yet I knew what a great man he was. I mean great in principle. I knew how necessary it was for our good that he should live." ${ }^{, 52}$ Winnemucca and her sister were, in fact, taken to the convent school in San José Truckee referred to but were there only three

\footnotetext{
${ }^{51}$ Ibid., 67.

${ }^{52}$ Ibid., 69.
} 
weeks before white parents complained about having Indian children attend the same school as white children and had them excluded. ${ }^{53}$

As noted earlier, Winnemucca taught herself English, Spanish and three other Indian languages. As she grew older she became a staunch advocate for Paiute English literacy and more than once served as an unpaid school teacher to Paiute and other Indian children on the various reservations she lived on. As early as 1870, the Daily Alta California ran an article titled, "An Indian Princess in the Sage Brush.” The journalist recorded Winnemucca to have said, "I am told, sir, that in California they are throwing away all the old school books and adopting new ones. I am anxious to teach our children to read and write; do you think that I could get some of the old ones? If I can, my father, brother and myself will form a school... and compel our people to send their children so that they may learn something as I have." 54 Winnemucca continued a personal crusade for the education of her people throughout her life which eventually resulted in the founding of a school in 1890 in Lovelock, Nevada. As we shall see, it was Boston women who supported this particular aspect of Winnemucca's reform agenda, but their support fell far short of Winnemucca's full definition of autonomy and middle ground citizenship for the Paiute.

Boston women were especially open to Winnemucca's ideas about Native education. Winnemucca did not, however, advocate an education accompanied by whiteimposed assimilation. She compared the schools she taught, "where the children were so

${ }^{53}$ Ibid., 70.

54 “An Indian Princess in the Sage Brush,” Daily Alta California, August 29, 1870. 
happy in learning," to the Reservation schools, "where they were whipped and taught nothing, but on which the Government wasted millions of dollars every year" a shrew appeal to economic self-interest. ${ }^{55}$ Winnemucca's ideas about education revolved around Indians, who knew their native tongue as well as English, simply teaching their own tribal members English literacy - a far cry from the complete assimilation encompassed in reform women's education agendas. As Elizabeth Peabody noted in 1886: "Indian education... hitherto has been necessarily so imperfect, because (it is) conducted by instructors who did not know any Indian language." Peabody wrote that Winnemucca was, "inspired from her infancy with the idea of civilizing her people by making English also their vernacular, and preparing the scholars in their turn to teach English to their companions and their parents, as children can best do." $" 56$ Boston audiences equated education with "civilization" and assimilation, which was inconsistent with Winnemucca's agenda. Winnemucca's education plan differed from plans espoused by many white reformers in that she recognized the value of Indians as educators. As Elizabeth Peabody more fully explained in her pamphlet, Sarah Winnemucca's Practical Solution of the Indian Problem, “...the reason that [Winnemucca] feels me to be her mainstay is that I do not bother her with my suggestions...because I see that she knows, as I cannot, how [the Indian mind] is to be approached and set at work..."57 Winnemucca argued that "education" should not involve the destruction of Indian

\footnotetext{
${ }^{55}$ Elizabeth Palmer Peabody, "Sarah Winnemucca's Practical Solution of the Indian Problem," Facsimile of the first edition from Cambridge: J. Wilson and Son, 1886, in History of Women 3539-3553, Corvallis, OR: Oregon State University, 14.

${ }^{56}$ Ibid., 15.

${ }^{57}$ Ibid., 12.
} 
children's tribal identities and she recognized the importance of teaching the children through literate Indians who knew and understood both languages and cultures. Peabody was herself more open and flexible than other Indian reformers in her community, and for reasons detailed in chapter three, became Winnemucca's best, if still limited, champion.

\section{Conclusion}

Winnemucca's normative rights language afforded her opportunities to work with Eastern reformers and gained her significant, well-publicized audiences along the East Coast. Reformers' petitions to Congress to (a) fulfill and maintain their treaties with the Indians, (b) build schools on every reservation for the purposes of educational and industrial training, (c) allot land in severalty to Indians who wanted it, and (d) grant Indians full rights under the law seem to be exactly what Winnemucca advocated and wanted for her tribe. Yet, while Winnemucca used the same vocabulary as the Eastern reformers to discuss citizenship, Winnemucca's definition of citizenship and whites' definition of citizenship were fundamentally distinct. Winnemucca championed Paiutes' sovereignty, while whites' foundational underpinnings of citizenship demanded that Indians internalize individualism and Christianity and--at least theoretically--eventually meld into the U.S. body politic through nationalist citizenship. Although Winnemucca found common ground with white middle-class reform audiences regarding normative rights (as in "law abiding"), English language education and morality, her eschewing of Christianity and insistence on Paiutes' maintaining their tribal traditions eventually 
proved a stumbling block to her obtaining lasting assistance from reformers. The opposition she encountered from the dominant reform organizations of her day was based largely on her rejection of Christianity as a prerequisite to and training ground for citizenship - while Winnemucca's arguments were discordant with these organizations and the arguments drew opposition, interestingly it was not the merits or flaws of her arguments themselves that drew the most negative attention and scrutiny, but rather attacks on her own personal morality and virtue. Winnemucca's positions regarding Christianity were predominantly undermined in public discourse by personal attacks and the dominant stereotypes of Indian hyper-sexuality and "immorality." Gender, especially notions of proper women's roles and family relations, was an important container for the Christianization agenda. The final chapter explores how gender and negative appraisals of Native women's identity and morality further undermined Winnemucca's cause. 


\section{CHAPTER THREE}

\section{RESISTING GENDERED VIOLENCE:}

\section{STRUGGLES IN THE PUBLIC SPHERE}

Winnemucca's public voice gained substantial momentum when she realized she might have the power to, as Zanjani put it, "bring the pressure of public opinion to bear on national government." 1 She applied this pressure initially through newspapers and lectures in the 1870s. Winnemucca's engagement with journalists and print news media and her attempts to control her image through them evince that she understood their power to influence; she likely read multiple newspapers herself, keeping abreast of current events reported in them. ${ }^{2}$ Her decision to begin lecturing in 1879 was probably influenced by her awareness of the success of her contemporary, the Ponca chief Standing Bear, a case widely reported in the media. ${ }^{3}$ Winnemucca's public voice leveraged the press and the platform to combat the Indian woman's hyper-sexual identity, and was based in the gendered rhetoric of womanhood, motherhood and morality. As Winnemucca's reform efforts progressed, her voice regarding Indian women's sexuality and the rape of Indian women grew louder - beginning as a whisper in San Francisco,

\footnotetext{
${ }^{1}$ Sally Zanjani, Sarah Winnemucca (Lincoln: University of Nebraska Press, 2001), 197.

${ }^{2}$ Carolyn Sorisio, "Playing the Indian Princess? Sarah Winnemucca's Newspaper Career and Performance of American Indian Identities," Studies in American Indian Literatures 23, no. 1 (May 14, 2011): 1-37.

${ }^{3}$ As noted in chapter two, Standing Bear successfully gained a measure of political redress from whites earlier that year by taking his tribe's grievances before audiences in the East.
} 
growing to a steady hum during her lectures in Boston and reaching a crescendo in the narrative she published in 1883. During her first lectures in San Francisco in 1879 Winnemucca described the rape of Indian women as "incidental;" however, by the time Winnemucca arrived in Boston she began voicing rape as the "foundational" means for whites to incite conflict and exert power and control over Indians and, as this study tries to show, it served as a foundational point for Native resistance.

As her message and popularity progressed, Winnemucca achieved mixed results that were sometimes promising but more often disappointing. Audiences in the East in particular were receptive to her gendered attacks on abuses and rape, her appeals regarding normative rights, her arguments for land ownership and her aspirations regarding education reforms. As this chapter will address, however, in the end her support was ultimately limited not only by her rejection of Christianity as a pre-requisite to citizenship and her preference toward "soldier-fathers" as opposed to missionaries, but also profoundly by attacks on her personal virtue. Several of her fiercest opponents undermined her public voice by attacking her virtue, capitalizing on Indian woman hyper-sexual stereotypes. Winnemucca redirected attention to the rape of her people, but her ability to combat these stereotypes was undermined by her rebuttal of Christianity her womanhood was almost by definition "degraded" due to her rejection of the notion that Christianity protected and uplifted womanhood compared to "heathenism." In the face of unfounded attacks, Winnemucca's posture towards Christianity and stereotypes of the hypersexual Indian woman identity left her vulnerable to charges of prostitution and 
promiscuity and ultimately limited her success in achieving her aims for her people. This chapter provides background to the battle that ultimately culminated in Boston and addresses the competing arguments both articulated by and entrenched against Winnemucca's public voice.

Winnemucca's life work demonstrates and extends the theorizing of Castañeda, who places the sexuality and rape of native women at the center of colonial relations in the settlement of the Americas. ${ }^{4}$ Unlike her biographers, who mostly overlook what Winnemucca had to say about sexuality and sexual violence, in this chapter I argue that Indian women's sexuality was a foundational theme in Winnemucca's public discourse, and her consistent focus on this theme underscored her lived reality. Not only did hypersexual stereotypes persist among many subaltern women of her day, but the personal sexual attacks that Winnemucca endured from government officials and reformers alike provide critical context for her challenge to colonization and its justifications in public. Further, I argue that ultimately personal accusations as well as

${ }^{4}$ Castañeda writes, "Generalizations about women of color perpetuate pernicious stereotypes. Native American, Chicana, African-American, and Asian American scholars have identified two dichotomous images of women of color in the literature - 'good' and 'bad.' ...Within this dichotomy, 'good' women of color are light-skinned, civilized (Christian), and virgins. They are 'good' because they give aid, or sacrifice themselves, so that white men may live; white men marry them. 'Bad' women are dark-skinned savage (non-Christian), and whores; white men do not marry them. This image simultaneously sexualizes women and impugns their sexuality. The implicit sociopolitical message is clear: women of color are immoral because their peoples, races, and nations are immoral...The devaluation of the sexuality of women of color, and by extension the devaluation of their people, was an important element in the rationale for war, conquest, exploitation, and subsequently exclusion. It was-and remains - a central part of the racist argument that served the political and economic interests of an expansionist United States." Antonia Castañeda, "Women of Color and the Rewriting of Western History: The Discourse, Politics, and Decolonization of History," Pacific Historical Review 61, no. 4 (November 1992): $517,519$. 
East Coast audiences' rejection of her proudly unconverted "heathen" identity undermined Winnemucca's reform agenda. While Winnemucca's gendered and "normative rights" language appeal initially won her large audiences and increasingly sympathetic ears, later her detractors' demonization of her as "heathen" and hyper sexual Indian woman undermined her reform efforts. By naming rape, Winnemucca raised the scepter of unruly sexuality which persistently slid off white male perpetrators and stuck to native women's reputations and bodies, including her own.

\section{Lighting the Fire of Winnemucca's Activism}

Two events in Winnemucca's life during the years 1878 and 1879 culminated to light the fire of Winnemucca's activism. The first was Winnemucca's service in and the results of the Bannock War of 1878. The second was Winnemucca's first experience with the beginning of a series of sexual slanders made against her personally to the Office of Indian Affairs by the Paiutes' Malheur Indian agent, William Rinehart. For years leading up to the Bannock War of 1878 the Paiutes had suffered afflictions of every kind. Zanjani notes their, “...fruitless attempts to collect rentals and payment for Indian lands, conferences with white officials, raids, and even (intermittent) warfare had not brought them subsistence enough to compensate for all they had lost," from white encroachment on their lands. ${ }^{5}$ The abuses the Paiutes suffered at the hands of their corrupt Indian agent on their Malheur Reservation were numerous. Rinehart sold government provided Indian

\footnotetext{
${ }^{5}$ Zanjani, Sarah Winnemucca, 71-72.
} 
rations to white settlers as well as leased Malheur Reservation land to white settlers and their herds. These actions resulted in the systematic starvation of the Paiute people. Other Indian groups in the area were suffering similar scenarios of destitution as well. In May of 1878 the local Bannock Indians declared war on the white settlers in the area. General Crook, brigadier-general and Commander of the Department of the Platte, described the environment in which the conflict began to brew as follows

In regard to the Bannocks I was up there last Spring, and found them in a desperate condition...They have never been half supplied. The agent has sent them off for half a year to enable them to pick up something to live on, but there is nothing for them in that country. The buffalo is all gone, and the Indian can't catch enough jack rabbits to subsist himself and his family... What are they to do! Starvation is staring them in the face and if they wait much longer they will not be able to fight...All the tribes tell the same story. They are surrounded on all sides, the game is destroyed or driven away, they are left to starve and there remains but one thing for them to do - fight while they can. ${ }^{6}$

Betrayed by the government's agency and commissioners, Winnemucca's band of Paiutes decided to side with the U.S. Army in war. From their first encounters with armed settlers, Winnemucca's band of Paiutes decided that they were far outnumbered and that fighting settler whites would be futile, even though the Bannock and Shoshone determined to raid the colonizers for food rather than starve without honor. For a starving people who believed that the Indians had no chance of success in war with whites, siding with the army seemed a better alternative to a series of raids that only

\footnotetext{
6 "It Is Hard to be Forced to Kill Them When They are Clearly in the Right," New York Times, June 23, 1878. See also George Francis Brimlow, The Bannock Indian War or 1878 (Caldwell: The Caxton Printers, Ltd., 1938), 39.
} 
brought retribution and more violence. ${ }^{7}$ During the Bannock War of 1878 Winnemucca served as military scout and interpreter for acclaimed U.S. Army General Oliver O. Howard. Her people, by letting themselves be taken into U.S. Army custody, were fed and clothed by the army for the duration of the war. During this war Winnemucca and members of her tribe not only aided the U.S. Army but helped individual white settlers escape the destruction of Indians on the war path.

When the war was over in September of 1878 Winnemucca and her people returned to the Malheur Reservation where Winnemucca resumed her government paid position as interpreter for her tribe. Here she re-entered the troubled terrain of her relationship to the Malheur Reservation's agent William Rinehart. In the years up to the Bannock conflict, Winnemucca refused to lie to her tribe for Rinehart and constantly exposed his stealing from and abuse of her tribe members to her people. In her narrative Winnemucca highlighted the tyranny of this man by recounting an experience she witnessed between Rinehart and a young Indian boy. She wrote, "I heard such a scream! I looked round, and to my horror saw our agent throw a little boy down on the ground by his ear and kick him..." She then records that Rinehart looked over at her and said, "Sarah, that little devil laughed at me, because I asked him to go and tell Jarry that I wanted him to come to my house. I will beat the very life out of him. I won't have any

\footnotetext{
${ }^{7}$ Generally, Winnemucca's band's philosophy of Paiute/white relations remained one of trying to keep the peace between the two races. Winnemucca's band's pragmatic reasoning for siding with the army during this war was the army's promise that, as official hostages of the US Army, her people would be supplied with food, clothing, protection and shelter for the duration of the war. See Sarah Winnemucca Hopkins, Life Among the Piutes: Their Wrongs and Claims (Reno: University of Nevada Press, 1994), chapter one.
} 
of the Indians laughing at me." Bannock War, Winnemucca and her starving people decided to leave the Malheur agency in search of food and redress at Camp Harney, a military base 20 miles from the agency. Rinehart blamed Winnemucca for driving the Paiutes away from the agency and officially dismissed her as interpreter.

When Winnemucca and her people arrived at Camp Harney she and the camp's sympathetic commanding officer wrote to the Office of Indian Affairs reporting Rinehart's abuses. In her narrative Winnemucca wrote,

We told the commanding officer (of Camp Harney) everything about our Christian agent's doings, and he told me to write to Washington, and he would do the same. I did as I was told; and when I had written it all the head men of my people signed it, and then our Christen agent discharged me from my office of interpreter, for reporting him to the army officers, for which I don't blame him.'

Winnemucca wrote down the charges against Rinehart for withholding Indian rations from the Paiutes and selling them to anyone who could afford them at his agency store and sent these to the Office of Indian Affairs in Washington, D.C. The Commissioner in charge then queried Rinehart about "needlessly transporting supplies to (the Malheur) agency," when the Indians were not at the Malheur reservation, and inquired "How is

\footnotetext{
${ }^{8}$ Ibid., 128.

${ }^{9}$ Here again Winnemucca critiques Christianity and highlights its ineffectiveness in inducing whites to more humane action. Ibid., 134.
} 
this, and why are your Indians off the Reservation?"10 Most likely the Commissioner's response came about because Winnemucca's letter was accompanied by a letter from Major Green, the commanding officer at Camp Harney who was friendly to the Paiutes and had written letters to Washington on their behalf before. ${ }^{11}$ This early scenario highlights dynamics consistent in the narrative: Winnemucca's ability to find a moral voice of outrage in service of her people in alliance with key "soldier-fathers" with relationships to her tribe.

Rinehart denied the allegations and blamed Winnemucca for causing trouble. He claimed that the commanding general at Camp Harney had, "acquired his prejudice against myself and my conduct from one Sarah Winnemucca, a low, unprincipled Indian woman of questionable virtue and veracity as well, who was formerly Interpreter at the Agency and who was discharged by me for untruthfulness, gambling and other bad conduct." ${ }^{\prime 2}$ Winnemucca's willingness to speak out, a tactic essential to Paiute survival, and her attempts to gain traction against injustice were used against her as suspect, selfish and "unwomanly" behavior. Slandering her morals and linking the charge of political duplicity to illicit sexuality was a standard way of discrediting subaltern women in the nineteenth century as numerous scholars, like Castañeda and Smithers have stressed. ${ }^{13}$ The only allegation in Rinehart's letter that directly addresses her performance as

\footnotetext{
${ }^{10}$ Special File of the Office of Indian Affairs, "The Case of Sarah Winnemucca," M 574, Roll 74, File 268 (Washington, DC: National Archives), 58. Letter Dated Feb 6, 1879.

${ }^{11}$ Zanjani, Sarah Winnemucca, 135.

${ }^{12}$ Special File, "Case of Sarah Winnemucca," 61. Letter dated February 6, 1879.

${ }^{13}$ Castañeda, "Women of Color," 501-533. See also Gregory D. Smithers, "The "Pursuits of the Civilized Man': Race and the Meaning of Civilization in the United States and Australia, 1790s1850s," Journal of World History 20, no. 2 (2009): 245-272.
} 
interpreter is his accusation that she was "untruthful;" all the other allegations he makes are directly aimed at her character, specifically her sexuality. Instead of defending his actions for requesting Indian supplies from the government when there were no Indians living on his assigned reservation, Rinehart used a tactic he thought more effective - that of discrediting the Indian woman's words by accusing her of hyper-sexuality and promiscuity.

Rinehart's slander against Winnemucca proved a turning point in her consolidation of her cultural resources as an activist. Rinehart's attacks on Winnemucca's sexuality undermined her efforts to self project as an exception to prevailing prejudices toward Indians by characterizing herself as the "Indian princess daughter" and/or "moral Indian mother" of her tribe - both acceptable Indian identities believed by whites to be morally clean and therefore worthy of attention. Rinehart's labeling Winnemucca a "low unprincipled woman," situated her within the "squaw drudge" and "exotic" Indian women categories and gave whites the moral license they needed to disregard her voice. Winnemucca understood the foundations of his attack and would soon begin a personal crusade to combat the dominant and false hyper-sexual stereotype of Indian women. Indeed, Winnemucca's political voice would eventually refute Indian hyper-sexuality and condemn rape of Indian women as a foundational practice of colonialism. It took some time for Winnemucca to learn of these specific charges though it is reasonable to speculate she was aware of the presuppositions and prejudices in her world. Rinehart's letters sat in her file in Washington for a few years 
until mobilized, as we shall see, by another white man with a political motivation to publicly discredit her in the media.

One month after Winnemucca and her people arrived at Camp Harney and Rinehart began his personal, if private, attacks on Winnemucca, she received terrible news. Winnemucca's "soldier-father" friends had been ordered to indiscriminately exile all Indians in the area, including the Paiutes, to the Yakama Reservation in Washington as punishment for the Bannock War. In November of 1878 the Paiutes were removed from Camp Harney and sent to Yakama. Winnemucca was furious; her people had sided with the U.S. Army during the Bannock War and had saved white settlers' lives. Now they were being punished as exiles on a strange and unfamiliar reservation. Winnemucca's people begged her to help. Emboldened by their service to the U.S. during the Bannock War, not only did her people want to return to their previous reservation, the Malheur reservation, but before they would go back they wanted their corrupt Indian agent Rinehart replaced. Winnemucca understood that in order to gain redress for her people her options were limited. As Zanjani points out, since "Washington had decreed the exile (of her people to the Yakama Reservation)...only an order from Washington could bring freedom." ${ }^{14}$ Instead of writing yet another letter to Washington pleading for the release of her people from the Yakama reservation, Winnemucca resolved to go to Washington herself. First, in order to earn the money she

\footnotetext{
${ }^{14}$ Zanjani, Sarah Winnemucca, 197.
} 
would need for her trip to Washington, Winnemucca decided to try to earn money by lecturing in San Francisco.

\section{Winnemucca Lectures in San Francisco}

After the Bannock War, Winnemucca and some of her close family members already widely recognized leaders of the Paiutes, had achieved some celebrity among whites in the area for helping the settlers escape the Bannocks during the war. And, in November 1879 , Winnemucca decided to leverage that popularity to take to the stages of San Francisco and lecture on the Indian cause. San Francisco marked the beginning of Winnemucca's lecture career, one which would eventually include Life Among the Piutes which she sold to audiences after her lectures. While it is apparent that Winnemucca went to San Francisco to earn money for a trip to Washington as well as to experiment with lecturing on the Indian cause to mobilize public action, she also began to name the rape of Indian women as the catalyst for sparking white/Indian conflict. Winnemucca's voicing of the rape of Indian women transitioned from timid to progressively bolder over time. San Francisco is significant in that it marked the beginning of her public discourse on the rape of Indian women and against their perceived sexual immorality.

Winnemucca went to San Francisco in part hoping to earn enough money for a trip to Washington to speak with the "Great Father" about the Paiutes' plight, and she knew from personal experience that Indians could be a spectacle in a large city - she 
knew that Indian shows were entertaining and whites paid money to see them. Historian

Noreen Groover Lape noted,

Interestingly, even before she wrote her autobiography, Hopkins

(Winnemucca), her father, and her sister Elma exploited their double consciousness and drew on stereotyped representations in performing tableaux vivants for white audiences. As a female acquaintance of the Paiutes wrote in an editorial their '(Chief Winnemucca's) object in so doing (was) to raise money to buy food and blankets for his people.' The stage show was shaped to entertain, not to depict the reality of Paiute life. The tableaux vivants indicate that the Winnemuccas were cognizant of their white audience's assumptions regarding Native Americans and used that knowledge to create profitable entertainment. ${ }^{15}$

Additionally, Winnemucca was likely aware of the success of her contemporary, the

Ponca chief Standing Bear. In the year prior to Winnemucca's lecturing in San

Francisco, Chief Standing Bear had won a District Court case in Omaha, Nebraska in

1878. He had secured for himself the definition as a "person" within the meaning of the laws of the Untied States," and had gained "the right to sue out a writ of habeas corpus in a federal court" but had not, as yet, successfully gained any redress from the federal government. ${ }^{16}$ The Boston Indian Citizenship Committee - the committee that would eventually help Chief Standing Bear gain monetary redress from the government - had formed on November 26, 1879, just two days after Winnemucca began her lectures in

\footnotetext{
${ }^{15}$ Noreen Groover Lape, "'I Would Rather Be with My People, but Not to Live with Them as They Live': Cultural Liminality and Double Consciousness in Sarah Winnemucca Hopkins's Life Among the Piutes: Their Wrongs and Claims," American Indian Quarterly 22, no. 3 (Summer 1998): 270. For more on these early performances see Gae Whitney Canfield, Sarah Winnemucca of the Northern Paiutes (Norman: University of Oklahoma Press, 1983), chapter four.

${ }^{16}$ Francis Paul Prucha, The Great Father: The United States Government and the American Indians, vol. 1 (Lincoln: University of Nebraska Press, 1984), 568.
} 
San Francisco. Winnemucca likely went to San Francisco with two objectives: first, she intended to combine spectacle and persuasion among the less hostile audiences of the western city in order to earn enough money to get to herself to Washington, and second, she intended to move San Francisco whites toward political action on the Paiutes' behalf. She achieved the first objective, but was unable to satisfactorily achieve the second.

When Winnemucca began her lecture career in 1879 part of her purpose was to appeal to the public to somehow have Rinehart dismissed as Indian agent of the Malheur Reservation so that her people could live on part of their homeland unfettered by his tyranny. Given the recent and explicit bills of grievances against this particular agent, Winnemucca singled out Rinehart by name on the stage as the quintessential "evil Indian agent" blocking the successful civilization of Indians. Winnemucca's mission to have Rinehart removed from his post and to have her people returned to the Malheur reservation began a personal war between herself and the Indian agent. Underscoring the power of words and the import of print and repetition to establishing authority, Rinehart lost no time in defending his position at Malheur to the Commissioner of Indian Affairs by campaigning against Winnemucca. Though, at this time Winnemucca touted Rinehart's abuses from the stage, Rinehart defended his position as government agent via letters to influential Indian officials and reformers in which he attacked Winnemucca's character and labeled her a prostitute. Rinehart's attacks most likely contributed to Winnemucca raising the stakes in print when publishing her autobiography. Winnemucca's autobiography contains a strong undercurrent championing Paiute 
women's morality. Winnemucca delivered her first lecture on November $25^{\text {th }}, 1879$, at Platt's Hall in San Francisco, California earning her a headline in the Daily Alta California newspaper, which ran the next day titled, "Princess Sarah, Her Lecture on Indians at Platt's Hall, Last Night." $" 17$ Winnemucca's lectures continued at Platt's Hall for a month and ended just before Christmas of that year. ${ }^{18}$ For her lectures in San Francisco Winnemucca chose to play the role of the stereotypical Indian princess. This period marked the beginnings of the phenomenon historians have termed "playing Indian" in U.S. society, indeed four years later William Cody would debut his first widely popular "Wild West Show" the same year Winnemucca began lecturing in Boston. ${ }^{19}$ Audiences had come to be entertained by an "exotic other," so she heightened her appeal by playing to white expectations of the Indian princess. Rather than wear the clothing a Paiute Indian woman would have worn, she wore a headdress of feathers, a buckskin skirt, a cape trimmed with beads and beads around her neck and wrist. Her costume might have been considered a little provocative judging by the reporter's comments, "Bright red hose showed below the short skirt, and it might have been the pair of gaily-embroidered moccasins worn on the feet that attracted the attention of the men in that way." 20 Yet it wasn't just her costume that was provocative. According to the reporter Winnemucca was exotic simply because she was strange, a foreigner yet 'familiar.' Of her speech the reporter wrote, "Sarah speaks English with gratifying

\footnotetext{
17 "Princess Sarah,” Daily Alta California (San Francisco, CA), November 26, 1879.

${ }^{18}$ Zanjani, Sarah Winnemucca, 197.

${ }^{19}$ Prucha, Great Father, 713.

20 “Princess Sarah,” Daily Alta California (San Francisco, CA), November 26, 1879.
} 
fluency, yet has not a remarkable command of the language. Sarah's manner of speaking is most decidedly odd, and because of its oddity, attractive."21 Newspaper reviews of her lectures in San Francisco detailed Winnemucca's costume, the stage scenery and Winnemucca's appearance. One journalist recounted that the audience at one of Winnemucca’s lectures was, “...very warm-hearted, and appreciated Sarah’s witty and telling points, and rewarded them with rounds of applause."22

Although Winnemucca catered to her audiences' desires for entertainment by donning an "Indian Princess" costume, she used her stage time to plead for whites to help her people. And, not only were her costume details covered by the press, but more importantly, so too, was her message. During these lectures Winnemucca focused her comments on the Paiutes' enduring loyalty to whites during the recent 1878 Bannock War, and the suffering her people had endured at the hands of corrupt Indian agent Rinehart. She articulated to her audiences the injustice of exiling her peaceful people who sided with the whites in the Bannock War - to the Yakama Reservation. She also began to voice the rape of Indian women as an injury deserving redress and sympathy.

As Winnemucca experimented with audiences in San Francisco, she approached the controversial topic of rape gingerly and indirectly. From her very first lecture in November of 1879 , Winnemucca told her audience that the "trouble" that started for the Pyramid Lake War of 1860 (a three month long conflict between the Paiutes and local

\footnotetext{
${ }^{21}$ Ibid.

22 “The Indian Question,” Daily Alta California (San Francisco, CA), December 4, 1879.
} 
whites residing near Pyramid Lake) was the rape of two Indian girls by white men. She explained

One day there were two little girls missing from our tribe. Search was made for them. They could not be found. They had been taken into the house of two white brothers who promised them something to eat. They were timid at first, and did not want to go. But afterward they did and were kept and put down in a cellar. When the Indians looked for them they came to this house and the brothers said they had not been there. The Indians searched the house... The brothers said they did not know where the girls were, but the Indians knocked them down and found the opening in the floor. They opened the trap door and found the poor little girls, with their mouths all tied up so they could not speak. This started the trouble of $1860 .^{23}$

Later during this same lecture Winnemucca refers to the girls who were kidnapped by the white men and infers their assumed rape, saying, "But how can I teach my people to be good? Say to them, you must be good, and must not condemn the whole white race because they do wrong to a few of your women." 24 (Here it should be noted that, four years later, Winnemucca would confirm in her narrative, as well as in her lectures in Boston, that just before the Pyramid Lake War broke out two Indian girls were kidnapped and raped by white men. At which point she describes the girls as being found on a bed in a cellar and relates that when the Indian men learned of the girls' condition, "they at once killed both brothers and set fire to the house." $)^{25}$ However, during this first of her lectures, Winnemucca names but also dances around the subject of rape. First, Winnemucca initially calls the victims "captured girls," but later in this same lecture,

23 "Princess Sarah," Daily Alta California (San Francisco, CA), November 26, 1879.

${ }^{24}$ Ibid. (emphasis added)

${ }^{25}$ Hopkins, Life Among the Piutes, 71. 
when more pointedly naming "rape" with the word "wronged" she calls the victims "a few women.” By asserting that the victims were Indian women - not innocent Indian girls - Winnemucca leaves her white audience room to potentially blame the "hypersexual" Indian women for their fate. Second, Winnemucca links rape with a three month long skirmish that happened between the Paiutes and the whites nineteen years earlier. She cites an example of rape from nineteen years ago almost as if this rape was an isolated episode. Notably, Winnemucca refrained from discussing the rape that she would later claim led to the Bannock War - a war of much larger scale that took place less than a year prior to her lecturing in San Francisco. Nor does she discuss the many other rapes or threats of rape of Indian women that she later identifies for audiences in Boston. Her later conveyance of rape as pervasive, widespread and commonplace, contrasts sharply with her tentative, coded discussion of rape during her first lectures in San Francisco, and seems to suggest uncertainty about how this message would be received by her audience.

To avoid alienating her audience Winnemucca was additionally careful to identify the white wrong-doers victimizing Indians as separate from her audience, that is as "other bad white people." She distinguished her audiences as separate whites by saying things like, "If your people will help us, and you have good hearts..."26 By separating her audience from other antagonistic whites on the frontier, Winnemucca avoided alienating them while simultaneously making space for white sympathies. But Winnemucca was

26 “The Indian Question,” Daily Alta California (San Francisco, CA), December 4, 1879. (emphasis added) 
unfortunately not the only one to disassociate white San Francisco audiences from other wrong-doing whites; many San Franciscans believed themselves disassociated from the Indian problem as well. As evidence of their own perceived disassociation, one audience suggested to Winnemucca solutions to her problem. In a newspaper article titled, "Another Eloquent lecture by the Champion of Her Race - A Beautiful Story of the Traditions of Her People," the reporter noted,

Princess Sarah Winnemucca last night gave another of her charming and inimitable lectures on behalf of her people...Sarah was also somewhat 'put out' by the numerous suggestions of innumerable kind friends, each of whom suggested a course of action... On Monday, however, she will address her audience untrammeled by advice." 27

Through her lectures in San Francisco, Winnemucca intended to raise public activism on behalf of her people. But to her white audiences her shows were entertaining and aroused disassociated sympathy at best, likely leading to her eventual targeting of reform-minded Eastern audiences.

The public speaking tactics Winnemucca used in both her lectures and her narrative were successful in cultivating audience reception and interest. Her challenge would be to translate notoriety into political traction, no easy feat. During her month long lecture series in San Francisco most nights her audiences filled the hall. Additionally, "despite the fact that the hall she hired cost $\$ 30$ a night, she cleared $\$ 500$ to

27 “Sarah’s Appeal,” Daily Alta California (San Francisco, CA), December 7, 1879. 
spend in making the trip to the president."28 Despite this financial success however,

Winnemucca's last lecture in San Francisco reveals that Winnemucca viewed her

audiences' reception bitterly. She had hoped to invoke action on behalf of her people and

nothing, as yet, had been done to help them. While orating the last of her San Francisco

lectures Winnemucca turned her customary petitions for help into acerbic blame. Toward

the end of her lecture she departed from her usual explanations and pleas and said,

Can you blame my people for saying you care no more for us than the snake that's curled in the grass? Who first invented scalping, I want to know... You are just as bloodthirsty to kill my people, as my people to kill you...Y You come and kick our people from all directions, and call yourselves civilized and Christian...I will expose all the rascals...I am going East... ${ }^{29}$

Possibly, knowing this was the last of her lectures in San Francisco, Winnemucca allowed her fury at her audiences' apathy to show through. Having failed in her attempts to receive help from the citizens of San Francisco, Winnemucca left her San Francisco audiences and returned to her people on the Yakama reservation. ${ }^{30}$

\footnotetext{
${ }^{28}$ Katharine C. Turner, Red Men Calling on the Great White Father (Norman: University of Oklahoma Press, 1951), 167. See also "The Princess Winnemucca," Boston Transcript, June 14, 1883.

29 "The Piute Princess," Daily Alta California (San Francisco, CA), December 24, 1879.

${ }^{30}$ Winnemucca's declaration that she was, "going East," tells us that she was probably aware of the prevailing dichotomy of Indian sentiments among whites in the East versus whites in the West. Her understanding of this dichotomy may also explain her partially muted voice regarding the rape of Indian women as well as the emphasis she placed on entertainment and spectacle during her lectures in San Francisco. The post-Reconstruction country was divided over the cause and solutions to the Indian problem. "Easterners" and "Westerners" each asserted their own knowledge of the Indians to justify their treatment of them. Prucha noted that most often, "western sentiment expressed...that Easterners were unacquainted with the Indians and offered impractical solutions to the problems they did not really understand." Indeed, Senator Plumb of
} 


\section{Winnemucca Appeals to "The Great White Father" in Washington}

All was not lost, however, during Winnemucca's trip to San Francisco.

Winnemucca had raised enough of a stir in San Francisco that, "the Office of Indian Affairs and the Secretary of the Interior found the adverse publicity Sarah had aroused 'intolerable,'” and she earned herself, her father and her brother an all-expense paid summons to Washington to meet with the Secretary of the Interior. ${ }^{31}$ Winnemucca went to Washington with two items on her agenda. Her first was to obtain orders from the Secretary for her exiled people on the Yakama Reservation to return to the Malheur Reservation. Her second was to get the tyrannical Malheur agent, William Rinehart, replaced. For Winnemucca, however, Washington turned out to be a distinctly gendered experience on two counts. First, Winnemucca arrived in Washington armed with references from military officials in Nevada citing her and her band's assistance and allegiance to whites during the Bannock War. Winnemucca had sacrificed her personal perceived allegiance to Indians to help white men during the Bannock War and she hoped this service would bolster her arguments for fair treatment from the government for her

Kansas articulated this sentiment during a congressional debate on the Dawes Act when he remarked, "I have noticed, that interest of a certain kind in the Indian is in the exact ratio of distance from him, and perhaps I might add in increased ratio to their knowledge of him or his actual need." He remarked that (among Easterners) there were, "barrels of tears, oceans of sympathy for the Indians, and a fragmentary and passing word only for the men who suffered at their hands." And, as Winnemucca's experience in San Francisco shows, there was some truth to Senator Plumb's remarks. Westerner city dwellers were "charmed," sympathetic and disassociated. Prucha, Great Father, 613, 628.

${ }^{31}$ Turner, Red Men Calling, 167. 
people. But as Winnemucca would learn, she may have been predestined in Washington to play the self-sacrificial role of the Indian princess - helpmate of white men.

At the time of the Winnemuccas' visit, Secretary Schurz was caught up in the Chief Standing Bear debacle and it is very probable that he and his associates were trying to avoid more bad press when it came to the Indians. ${ }^{32}$ Secretary Schurz needed good press and the Winnemuccas were far enough removed from the East Coast that Schurz could make casual promises to them without necessarily being taken to task by Eastern reformers if he didn't follow through. Secretary Schurz did, in fact, receive much needed positive press among Eastern reformers for supporting the Dawes Act by officially granting the Paiutes land allotments on their beloved Malheur reservation seven years before the Act was actually passed in Congress. ${ }^{33}$ His promises were slipshod to say the least and he probably knew he would not officially enforce them. But Schurz's empty promises got him the positive press he needed - and when Winnemucca returned home after her visit to Washington in February 1880 - touting more unfulfilled promises from whites she was rendered an outcast among her people. Further, when Rinehart heard of Winnemucca's planned travel to Washington he knew that she was trying to have him replaced and he began stepping up his letter campaign to the Office of Indian Affairs regarding Winnemucca's character in an effort to discredit Winnemucca's statements against him. Rinehart also rallied his friends to write and sign affidavits on his behalf

\footnotetext{
${ }^{32}$ Ibid., See also Francis Paul Prucha, American Indian Policy in Crisis: Christian Reformers and the Indian, 1865-1900 (Norman: University of Oklahoma Press, 1964), 568-69.

${ }^{33}$ Turner, Red Men Calling, 167.
} 
addressing Winnemucca's character. All of the men who wrote letters or signed affidavits on Rinehart's behalf were friends, relatives or business associates of Rinehart's. Rinehart sent these letters titled, “Transmitting Affidavits in Relation to Character of Sarah Winnemucca," to the Office of Indian Affairs on Jan 15, 1880. Though the letters probably did not reach Washington until after Winnemucca's visit, they were put into the Indian Bureau files on Sarah Winnemucca, entitled, "The Case of Sarah Winnemucca" Special File 268. ${ }^{34}$ While Winnemucca was probably not aware of the letters Rinehart sent Washington, these letters would later come back to haunt Winnemucca when she hit the lecture circuit in Boston.

Winnemucca, her father and her brother met with Secretary Schurz twice. At their first meeting on January $21^{\text {st }} 1880$, Schurz asked Winnemucca to recount the events of the Bannock War to him. ${ }^{35}$ According to her narrative, Schurz then invited the Winnemuccas to come back to his office the next day. During this second visit she and Natchez made their requests for the release of their people from the Yakama reservation and a new agent to be placed on their homeland Malheur reservation, and Schurz promised to grant their requests. Upon the completion of their visit to Washington, Schurz gave Winnemucca a letter stating

The Pi-Utes, heretofore entitled to live on the Malheur Reservation, their primeval home, are to have lands allotted to them in severalty, at the rate of one hundred and sixty acres to each head of a family, and each adult male. Such lands they are to cultivate for their own benefit. The

\footnotetext{
${ }^{34}$ Special File, "Case of Sarah Winnemucca," 268. See also Canfield, Sarah Winnemucca of the Northern Paiutes, 204.

${ }^{35}$ Zanjani, Sarah Winnemucca, 204.
} 
allotment will be made under instructions of their agent. As soon as enabled by law to do so, this department is to give to the Indians patents for each tract of land conveying to each occupant the fee-simple in the lot he occupies. Those of the Pi-Utes who in consequence of the Bannock war, went to the Yakama Reservation, and whoever may desire to rejoin their relatives, are at liberty to do so, without expense to the government for transportation. Those who desire to stay upon the Yakama Reservation and become permanently settled there will not be disturbed... ${ }^{36}$

In the above letter, Schurz granted the Paiutes land in severalty on the Malheur Reservation and deemed that the Indian agent of Malheur would be in charge of allotment. Had Schurz actually listened to the Winnemucca delegation sitting in his office, and if he was sincere in granting them land in severalty, he would have made provisions to have agent Rinehart replaced. Winnemucca wrote in her narrative of their meeting with the Secretary, “...neither my father or brother made any agreement to go to Malheur...till Rinehart should be sent away."37 That Schurz would think that Rinehart would freely allot the Paiutes land when Rinehart had been refusing to give them their rations is doubtful. Possibly Schurz thought his "official letter" to Rinehart would force Rinehart's compliance. But more likely, Schurz was well aware of the prevalent corruption among Indian agents that so devastatingly affected Indians across the nation and his letter was an insincere publicity tactic. Of the letter Winnemucca wrote, "Just think how happy I was! To go for my poor sick-hearted people. Yes, armed with a paper signed by Secretary Schurz. I thought I would not have anything to do but go there (to

\footnotetext{
${ }^{36}$ Hopkins, Life Among the Piutes, 224.

${ }^{37}$ Ibid., 221.
} 
Yakama) and get them..."38 Indeed the Winnemuccas were excited about their meeting with Schurz. They thought they had finally gained the official redress they needed from the "Great Father" in Washington that their autocratic Indian agents would have to comply with. But Winnemucca soon learned that the "Great Father" in Washington was actually as callous to their cause as the white men she knew at home. None of the promises Schurz made to her and her family were kept. Her people remained in exile at Yakama. When Winnemucca showed her official letter from Secretary Schurz to the local Indian agents it was ignored. She later said of the letter and promises Schurz made to her that they, "like the wind, were heard no more."39

As noted in chapter one, during their second meeting with Secretary Schurz January 1880, Schurz asked Winnemucca not to lecture in Washington and attempted to bribe her into returning home immediately. Schurz promised to send her one hundred tents that she could issue to her people as soon as she got home. Winnemucca recognized this as a bribe and with her usual distrust of white promises decided to lecture in Washington anyway. According to her narrative, Winnemucca lectured in Washington and within a month returned to the Yakama reservation to be with her people. Interestingly, of the newspaper articles printed on the East Coast that mention the Winnemuccas, during the time they visited Washington and the time that Winnemucca records that she lectured there, neither the Washington Post nor the New York Times mentions Winnemucca's lectures. Rather, both of these papers discussed Secretary

\footnotetext{
${ }^{38}$ Ibid., 226.

${ }^{39}$ Ibid., 228.
} 
Schurz' promises to the Paiutes in detail and relayed the Paiutes' delight with their experience in Washington. ${ }^{40}$ Secretary Schurz received his positive press and successfully sent the Piute delegation home without securing injury from Winnemucca's short-lived lectures in the East. These early articles reporting that Secretary Schurz had given the Paiutes all they asked for meant that Winnemucca had lost control of the media spin in Washington. She could lecture on previous grievances, but had no leg to stand on when it came to the happy ending the papers touted for the Paiutes as a result of their meeting with Secretary Schurz.

When Winnemucca returned to her people on the Yakama reservation she recorded that she was eventually sorely discredited among them for telling them more white lies. The agent at Yakama ignored Schurz's letter and threatened to have Winnemucca locked up if she read it to her people on the Yakama reservation. Angrily she said to him, "I don't care how soon you have it done. My people are saying I have sold them to you, and get money from you to keep them here. I am abused by you and by my own people..."41 Having relayed empty promises from the "Great Father" in Washington and, having been exiled to Yakama by the military men she persuaded her people to side with during the Bannock war, Winnemucca was, to say the least, disheartened. In her narrative she wrote, "I almost wished he would put me in prison, for

40 "Notes From Washington: Secretary Schurz Had a Long Conference with the Piutes This Afternoon," New York Times, January 21, 1880. See also "Piutes to Support Themselves: Satisfactory Conclusion of the Conference," New York Times, January 25, 1880. See also "Another Delegation of Red Men: Chief Winnemucca and Party to Arrive - Jack and His Cheyenne Friend.” Washington Post, January 19, 1880.

${ }^{41}$ Hopkins, Life Among the Piutes, 240. 
that would have made my people see that I had not sold them."42 Winnemucca was yet again the victim of white men's colonial ambitions. She had helped them during the Bannock War, and her people were exiled to a foreign land. She trusted that her meeting with Secretary Schurz would bring her people redress and touted his promises among her people, but instead her presence gave Schurz the opportunity to obtain much needed personal positive press. Back out west, she was shut down in her attempt to expose the Secretary's promises to the point of being arrested and detained.

In need of money and unable to fully recover her reputation among her people from Schurz's lies, Winnemucca eventually left her people on the Yakama reservation. She took a government position as interpreter at Fort Vancouver. ${ }^{43}$ How long she actually stayed at Fort Vancouver is unknown.

\section{Boston: Winnemucca Meets Peabody}

Winnemucca's whereabouts during the time she returned from the "Great Father" in Washington and the time she decided to go to Boston and lecture remain largely unknown. In the last paragraph of her narrative Winnemucca writes, “After I left Vancouver Barracks I went to my sister in Montana."44 Three years after her fateful meeting with Secretary Schurz in 1880, disheartened but not defeated, Winnemucca

\footnotetext{
${ }^{42}$ Ibid.

${ }^{43}$ Zanjani, Sarah Winnemucca, 220.

${ }^{44}$ Hopkins, Life Among the Piutes, 246.
} 
decided to travel to Boston to embark on another lecture series in yet another effort to gain redress for her people. Historian Zanjani speculates that a lecture bureau might have invited Winnemucca to Boston to speak, and historian Canfield suggests it might have been the letter Winnemucca wrote to Major Douglas in 1870 that reappeared in Helen Hunt Jackson's Century of Dishonor - published and widely circulated on the East Coast in 1881 - that figured in Winnemucca's reappearance in the media spotlight on the East Coast. ${ }^{45}$ But the last sentence of Winnemucca's narrative is telling of her personal reasons for traveling to the East. She wrote, "I visited my people once more... and they urged me again to come to the East and talk for them, and so I have come."46 After a three year hiatus Winnemucca was, once again, ready to fight for her people. It was in Boston, and the subsequent East Coast cities that she lectured in that Winnemucca found her strongest voice for combating the hypersexual Indian woman identity and naming rape of Indian women as a foundational practice of white colonialism.

When Winnemucca arrived in Boston, in March of 1883, some of Winnemucca's people were still exiled on the Yakama Reservation and agent Rinehart was still guarding his post as agent at Malheur. How much Winnemucca knew about the audience reception she might receive in the East and why exactly Winnemucca chose Boston to begin lecturing is largely unknown. Potentially, as previously noted, Winnemucca was aware of the success of the Ponca tribe working with Boston reformers and it may have

\footnotetext{
${ }^{45}$ Zanjani, Sarah Winnemucca, 237. See also Canfield, Sarah Winnemucca of the Northern Paiutes, 199.

${ }^{46}$ Hopkins, Life Among the Piutes, 246.
} 
seemed to her that these reformers would be willing to help her as well. Though

historians cannot pinpoint exactly what Winnemucca knew about the political situation in the East, Winnemucca could not have begun lecturing in a better place. It was in Boston that Winnemucca met Elizabeth Palmer Peabody, a woman who would become a lifelong friend and supporter of Winnemucca's educational and political aspirations for the Paiutes. ${ }^{47}$ Winnemucca's eschewal of Christian assimilation for the Indians and her proposed third way toward Indian citizenship for the Paiute resonated loudly with Peabody. Of her first encounter with Winnemucca, Peabody wrote, "I have been a student of Indian history for more than seventy years...(she then goes on to cite the extensive reading on Indians that she has done)... All this, and acquaintance with the halfbreed Chippewa missionary Tanner, who...made in Boston precisely the same explanatory criticism on the vicious principle of all the missionary work for Indians that Sarah Winnemucca does, prepared me to appreciate and understand the first lecture I heard from her..."48 The fact that Winnemucca's criticism of missionaries did not offend Peabody as it did so many reformers, can be attributed to Peabody's strong adherence to

\footnotetext{
${ }^{47}$ As O'Connell noted, "Elizabeth was given to 'causes': both people and social issues...In 1860 Elizabeth Peabody established the first kindergarten in America, on Beacon Hill. Here as elsewhere she attempted to translate ideas into action, to realize herself by releasing the potential in others." At age sixteen Peabody founded her own school in Lancaster, M.A. She then became a devotee of William Ellery Channing, the embodiment of Boston Unitarianism, for she too held reason superior to revelation...Her Record of a School is an enthusiastic, sometimes confusing account of her faith in the transforming powers of education. She helped develop literary Boston when she arranged Hawthorne's Custom House position and when she underwrote the publication of the Dial. Shaun O'Connell, Imagining Boston: A Literary Landscape (Boston: Beacon Press, 1990), 59-60.

${ }^{48}$ Elizabeth Palmer Peabody, "Sarah Winnemucca's Practical Solution of the Indian Problem," Facsimile of the first edition from Cambridge: J. Wilson and Son, 1886, in History of Women 3539-3553, Corvallis, OR: Oregon State University, 27-28.
} 
transcendentalist values. Peabody's transcendentalism included the core beliefs that the purity of the individual was corrupted by society and its institutions such as political parties and organized religion. ${ }^{49}$ According to Peabody she had long recognized the plight of the Indian and, prizing self-direction above institutional direction, Peabody found in Winnemucca exactly what she was looking for when Indian reform seemed primed for refreshing in light of the recently publicized wrongs done to the Indians and the sensation around Century of Dishonor (1881). ${ }^{50}$

Winnemucca was a self-directed Indian woman initiating solutions to problems only an Indian woman could understand. In her pamphlet, Sarah Winnemucca's Practical Solution of the Indian Problem, Peabody articulates the sentiments she and Winnemucca shared when she wrote that,

...the majority of Indian agencies prevent civilization by insulting and repressing that creative self-respect and conscious freedom to act, from which alone any vital human improvement can spring... We wanted that there should be no pretext of favors received, for the agent, who naturally enough is (Winnemucca's) personal enemy, to interfere or meddle while she, with a few of her people, began self-supporting, self-directed life on ground of their inherited domestic moralities, which, in the case of the Piutes at least, are very pure, as (Winnemucca) had demonstrated to us in her lectures and by her own remarkable personality... ${ }^{51}$

${ }^{49}$ Clarence L. F. Gohdes, The Periodicals of American Transcendentalism (Durham, NC: Duke University Press, 1931), 4-5.

${ }^{50}$ Prucha, "Chapter 24: The New Christian Reformers," in Great Father. See also Canfield, Sarah Winnemucca of the Northern Paiutes, 203.

${ }^{51}$ Peabody, "Sarah Winnemucca's Practical Solution,” 8-9. 
Thus Winnemucca's "critique of civilization" that pointed toward a third way for Paiutes and whites to co-exist matched Peabody's sentiments, and the influential Boston socialite took Winnemucca under her wing and invited her to stay at her home. ${ }^{52}$ Together with her sister Mary Mann, Elizabeth arranged for Winnemucca's lectures and between the spring of 1883 and midsummer 1884 Winnemucca lectured in Boston, New York, Pennsylvania, Baltimore, Washington and the greater New England area. To inoculate themselves against sensationalism and profiteering, Winnemucca did not charge for her lectures, but did sell her book after her lectures and accepted donations on behalf of the Paiute tribe. Winnemucca would later use the proceeds from her book coupled with the donations she received from lectures to build a school for Paiute children. ${ }^{53}$

Elizabeth Peabody especially took Winnemucca's cause to heart. She diligently wrote letters to her friends and arranged for Winnemucca to speak in the homes of Ralph Waldo Emerson, John Greenleaf Whittier and several congressmen. ${ }^{54}$ Winnemucca remained with the Peabodys for six months, during which time she lectured and wrote and published her book, Life Among the Piutes: Their Wrongs and Claims. Peabody recorded that Winnemucca wrote the book from her "own deep impulse," to tell the entire story that she did not have time to tell in a single lecture. ${ }^{55}$ While at the Peabody home,

\footnotetext{
${ }^{52}$ Zanjani, Sarah Winnemucca, 236.

${ }^{53}$ From Elizabeth P. Peabody, Second Report of the Model School of Sarah Winnemucca, 188687 (Cambridge, MA: John Wilson and Son, 1887, cited in Zanjani, Sarah Winnemucca, 244.

${ }^{54}$ Zanjani, Sarah Winnemucca, 243.

${ }^{55}$ Ibid., 239.
} 
Winnemucca wrote the book in three months and within six months Elizabeth Peabody had it published with G.P. Putnam's Sons of New York, in $1883 .^{56}$

\section{Boston: Winnemucca's Political Opponents Attack Her Virtue}

Examples from Winnemucca's personal life, especially how her body, marital choice-making, and mothering (or lack thereof), were "read" by powerful U.S. authorities, male and female, provide a window into how whites capitalized on the hypersexual stereotype of the Indian woman to personally discredit individual Indian women. In this section I argue that Winnemucca's eschewal of missionaries and Christian assimilation alienated her potential support from reformers, especially the Women's National Indian Association. Further I contend that slanderous attacks on Winnemucca's personal virtue were a tactic used by reformers who disagreed with Winnemucca's political message to discredit her. These slanderous attacks in conjunction with the "heathen" identity forced on her by Christianizing reformers necessarily emboldened Winnemucca's voice combating Indian women's perceived sexuality and provide the context for her narrative's persistent rebuttal of charges of sexual immorality among Indian people, especially women. Winnemucca's biographers have cited her unpopular political message as the potential reason her political agenda was marginally successful in the East, but I emphasize the hyper-sexualization of Winnemucca both personally and as

\footnotetext{
${ }^{56}$ Ibid. See also Hopkins, Life Among the Piutes, title page.
} 
an Indian woman as additionally responsible for her brief celebrity and quick

marginalization in the early 1880 s. $^{57}$

During her lectures in Boston Winnemucca named rape and sexuality as provoking honorable self defense from Native people and as an indictment of "Christian civilization." She also promoted her version of Paiute citizenship that espoused Paiute sovereignty and the maintenance of native tradition. Winnemucca alienated her reform audiences when during her lectures she spoke harshly against missionaries, Washington officials and reservation agents, but spoke highly of the military and her interactions with soldiers. Each of these messages was at odds with the major reform groups' prescribed remedies for the Indian problem - and these reform groups might have helped her had she not challenged their solutions. Challenging rather than placating these audiences, Winnemucca's lectures included her own negative experience with missionaries. To one audience in Boston she, "told of the insincerity of the many missionaries and ministers who came in contact with her people, asking why they did not practice what they preached." ${ }^{58}$ To another audience she "deprecated the sending out of certain missionaries, whose practice was far from being in accordance with their preaching." Of Winnemucca's first lecture Peabody noted,

In that first lecture she offended, by her story of the conduct of the Methodist agent Wilbur, a Methodist lady, who endeavored to bribe her to say no more

\footnotetext{
${ }^{57}$ Zanjani, Sarah Winnemucca, chapter 14. See also Canfield, Sarah Winnemucca of the Northern Paiutes, chapter 20.

58 "Princess Winnemucca on the Treatment of the Indians," Boston Evening Transcript, May 3, 1883.

59 “Address of Princess Winnemucca," Boston Daily Globe, June 14, 1883.
} 
about him, by promising her hospitality and other assistance. But Sarah was obliged to tell her she had nothing else to tell but just such actions of agents as his. This started an opposition against herself at once, that succeeded in making the Woman's Association turn a cold shoulder to her. ${ }^{60}$

Though Winnemucca did report badly of a Methodist agent by the name of Wilbur to her audiences, it is unlikely that the Women's National Indian Association would have offered her much assistance anyway. The Women's National Indian Association's focus was missionary work and their typical reports noted that their work would continue until, "the Indian women and home are permitted to rise from pagan darkness, degradation, destitution and suffering into the light of Christian faith, nobleness, comfort and independence."61 Writes Prucha, "Not understanding a culture and a family life that differed so markedly from their own experience, the humanitarians saw only "heathen" practices which they felt it their duty to stamp out as quickly and as thoroughly as possible. Polygamy was a special abomination, and the whole tribal arrangement was thought to create and perpetuate un-Christian modes of life."62 Christian reformers were not ready to give up their control over the Indian question. Peabody wrote, with understatement, that Winnemucca did not receive support from Christianizing reform groups because, "already all the organized sympathy for the Indians in the East was preengaged; ... all the funds to be raised by the women's associations were pledged to their

\footnotetext{
${ }^{60}$ Peabody, "Sarah Winnemucca's Practical Solution," 24.

${ }^{61}$ V.S. Mathes, "Nineteenth Century Indian Women and Reform: The Women's National Indian Association," American Indian Quarterly 14, no. 1 (Winter 1990): 7.

${ }^{62}$ Prucha, Indian Policy in Crisis, 155.
} 
own missionary work," that is, evangelization. ${ }^{63}$ Christian women were set on "Christianizing" the "heathen" with its full range of assimilatory measures. Women reformers were more than willing to listen to the abuses done to the Indian by the government/military, but they would not hear Winnemucca's negative message about Christian missionaries. If Peabody was looking to challenge the ethnocentric, top-down traditions of Indian reform, she indeed found an excellent candidate in Winnemucca. However, it was Winnemucca who paid the price for speaking out in this way. By not adopting Christianity herself, Winnemucca was regarded as an unwilling "heathen" and thereby lost reformer support. This opposition is not surprising given the social landscape in which Winnemucca lectured. By not adopting Christianity, Winnemucca left herself more vulnerable among women reformers to attacks on her virtue, a fear that Peabody need never entertain for herself.

Winnemucca antagonized other reformers and government officials who wanted to keep Indian affairs under the control of the Indian Bureau when she touted the success of her "soldier-father" friends who, in her experience, treated the Indians fairly. The Boston Evening Transcript reported Winnemucca's position when it wrote, "She does believe and say that they (the Paiutes) would be infinitely better off in (the Army's) care than if left to the care of the agents, for the army, by its discipline is placed beyond the temptations that assail the agents, who can trade away the Indian rights with the

\footnotetext{
${ }^{63}$ Peabody, "Sarah Winnemucca's Practical Solution," 16.
} 
frontiersmen, who have demoralized the whole West during these two hundred years." To another audience Winnemucca said, "I assure you that there is an Indian ring; that it is a corrupt ring, and that it has its head and shoulders in the treasure at Washington."65 Military control of Indian policy was highly unpopular among Eastern reformers. Eastern reformers advocated an end to military presence on the reservations in favor of their own ministers and missionaries, who were increasingly their own daughters, trained in the seminaries of New England. Reformers held that the work with Indians now consisted of educating them and civilizing them, not subduing them, and that this was, "eminently civilian not military work," launching a gendered claim to the civilizing mission. ${ }^{66}$ Further, reformers believed that, "the effect of the common soldiers upon the moral condition of the Indians was universally bad."67 Winnemucca's message that the military was more humane than the agents and missionaries alienated reform audiences. ${ }^{68}$

This was particularly burdensome for Winnemucca because her entry into white reform circles was premised on their assumption that native people were "naturally" noble and fit for citizenship, granted they were first converted and "uplifted" to Christianity. Whites looking to discredit individual Indian women often used their stereotypic sexuality as key evidence against their perceived misdoings and Winnemucca

\footnotetext{
64 "Sarah Winnemucca the Piute Princess Speaks at Quincy on Sunday Night and Then Leaves Boston till September," Boston Evening Transcript (Boston, MA), July 7, 1883.

65 "Princess Winnemucca on the Treatment of the Indians," Boston Evening Transcript (Boston, MA), May 3, 1883.

${ }^{66}$ Prucha, American Indian Policy in Crisis, 91.

${ }^{67}$ Ibid.

${ }^{68}$ Canfield, Sarah Winnemucca of the Northern Paiutes, 203. See also Zanjani, Sarah Winnетисса, 247-48.
} 
was no exception. Enemy Indian agents and newspapers alike used this trope to assail Winnemucca's character and thereby, her political position throughout her public career. In other words, whites were able to capitalize on Indian women's perceived sexuality to justify their self-benefiting colonial actions.

This was particularly the case with agent William Rinehart, who used this tactic to defend his position as agent of the Malheur Reservation to the Commissioner of Indian Affairs in 1879. Rinehart's letters attacking Winnemucca's character were conveniently circulated throughout Boston four years after Rinehart wrote them by Thomas A. Bland. How Bland accessed these letters is unknown, but historian Canfield confirms that the letters written by Rinehart were kept on file with the Indian Bureau and, based on Winnemucca's oppositional political message, government officials who had access to her file certainly could have aided Bland in his endeavors. ${ }^{69}$ Bland, a reformer and publisher of The Council Fire and Arbitrator - a journal that enthusiastically reported on the reform organizations' affairs - used Rinehart's letters in an effort to silence Winnemucca's political message and further his own political/colonial agenda. Bland opposed Winnemucca on two fronts, both of which were related to her advocacy of the military as a go-between for her people verses civilian agents or missionaries. First, Bland opposed military involvement because, as a member of the National Arbitration League, he believed the Army acted haphazardly and that the use of force led to more Indian hostilities. Second, like many of his contemporary reformers Bland was of the

${ }^{69}$ Canfield, Sarah Winnemucca of the Northern Paiutes, 204. 
opinion that with the military in charge the Indians remained wards of the state and their dependency on the government inhibited their individualism. ${ }^{70}$

Two months after Winnemucca began her lectures in Boston, Bland's publication The Council Fire called Winnemucca, "an Amazonian champion of the Army who was being used as a tool of the army officer to create public sentiment in favor of the transfer of the Indian Bureau to the War Department." ${ }^{71}$ Shortly thereafter, in an attempt to mute Winnemucca's voice The Council Fire also published the letters and affidavits Rinehart had sent to Washington officials during Winnemucca's visit with Secretary Schurz in 1880. Through the use of these letters Bland attempted to squelch the publication of Winnemucca's book. And Zanjani documents that the disaster was only averted, "by the success of Peabody and Mann in raising a six-hundred-dollar subscription fund for Life Among the Piutes," donated from five of their friends. ${ }^{72}$

The success of the tactic of slandering an Indian woman's virtue, and thereby discrediting her voice is evidenced by the publicity the slanders received and the varying responses it solicited. First, Winnemucca, Peabody and Mann were well aware of the attack's ability to mute Winnemucca's public voice and they responded to the attacks by including twenty-four letters of character reference and proof of reliability written by Winnemucca's supporters in the appendix of Life Among the Piutes. Second, when Mann appealed to General Howard - a good friend of Winnemucca's who had often come to

\footnotetext{
${ }^{70}$ Prucha, Great Father, 90-91.

${ }^{71}$ Canfield, Sarah Winnemucca of the Northern Paiutes, 204.

${ }^{72}$ Zanjani, Sarah Winnemucca, 248. See also Canfield, Sarah Winnemucca of the Northern Paiutes, 206.
} 
her aid in the past - for a letter attesting to Winnemucca's character for the purpose of publishing it in Winnemucca's book General Howard declined. He wrote Peabody, "that a lady's reputation should not be discussed in the newspapers," and "should I write I should lay myself open to be assailed by the same bad man..."73 General Howard's response evidences he understood the severity of the attack on Winnemucca and wanted no part in the debacle. Alfred H. Love, President of the Peace Union at the time, and one of Winnemucca's supporters wrote a letter to The Council Fire in defense of Winnemucca. His question acknowledges the potential the slanders had to undermine Winnemucca, he wrote, “...if the statements you make be true, would it not be kind to keep them from the public(?),74 Of the debacle Winnemucca wrote a personal letter to the reader that she included in the appendix of her narrative, it reads, “...the government was deceived by the agent Rinehart...Everyone knows what a woman must suffer who undertakes to act against bad men. My reputation has been assailed, and it is done so cunningly that I cannot prove it to be unjust. I can only protest that it is unjust..."75 Aside from Winnemucca's controversial message that assailed missionaries, agents, and Washington officials - the content of Rinehart's letters successfully discredited Winnemucca and her message among Boston reformers. The slanderous attacks made it difficult for Winnemucca and her supporters to raise money for the Paiutes. One supporter of Winnemucca's and a friend of Peabody's wrote to Peabody, "(Your letter)...came about five minutes since. It is a great relief to me, for two reasons. First it

\footnotetext{
${ }^{73}$ Zanjani, Sarah Winnemucca, 249.

${ }^{74}$ Canfield, Sarah Winnemucca of the Northern Paiutes, 206.

${ }^{75}$ Hopkins, Life Among the Piutes, 258.
} 
gives me some facts, that I can use at discretion to answer slanders with which I am so often met, when I try to advocate the cause of the Piutes and of Sarah... and I have a little faith that...I may be able to add a mite to your bank of mercy and justice and truth."76 While Winnemucca's biographers touch briefly on the moral slander she endured in Boston, they tend to focus on Winnemucca's unpopular political message as responsible for her limited success in the East. I add that while Winnemucca's political message was unpopular, the effects of the attacks on Winnemucca's virtue must be considered when we attempt to explain Winnemucca's short lived experience among Eastern reformers.

The contents of Rinehart's letters are especially appalling when one considers the circulation and attention they received among Winnemucca's audiences in Boston. The letters and affidavits consisted of amoral accusations against Winnemucca signed by Rinehart's closest friends and business associates. ${ }^{77}$ A man named William Currey signed an affidavit that said, "I am acquainted with Sarah Winnemucca, former interpreter at Malheur Agency and have known her for the last four years...that she is generally regarded, where she is known, as untruthful and not entitled to be believed...she is generally regarded by those who know her, as a common prostitute and thoroughly addicted to the habits of drunkenness and gambling."78 In the above statement Currey cites that Winnemucca is "untruthful and not entitled to be believed,"

\footnotetext{
${ }^{76}$ Canfield, Sarah Winnemucca of the Northern Paiutes, 235.

${ }^{77}$ The group that helped write and sign the Rinehart letters included Rinehart's, "close business associates, either contractors at Malheur or earlier connections...a Rinehart employee, a relative of Rinehart's wife, and (settlers) who sought the...interest of encroaching settlers. In short, the 'best men in the country' were biased. Either they had a financial relationship with Rinehart or they had gone on record as opponents of Indian interests." Zanjani, Sarah Winnemucca, 207.

${ }^{78}$ Special File, "Case of Sarah Winnemucca," 115. (Attached affidavit dated January 15, 1880)
} 
not because he cites a specific example where she has lied but because she is a prostitute who drinks and gambles. Similarly, a Thomas O'Keefe wrote an affidavit stating,

I am a discharged Soldier from the United States Army...I have been personally acquainted with Sarah Winnemucca, former Interpreter at Malheur Agency, Oregon, for the last six years; that in consideration of a bottle of whiskey and \$5 I had illicit intercourse with the said Sarah Winnemucca; that between November $1^{\text {st }}$ and December $20^{\text {th }} 1878$ the Said Sarah Winnemucca sent me notes to meet her for the purpose of having intercourse with her; that in consideration of whiskey furnished her I had intercourse with the said Sarah Winnemucca between the dates specified; that she lived in open prostitution...that her reputation for veracity among citizens and soldiers is bad, the general impression being that she could be bought for a bottle of Whiskey. ${ }^{79}$

O'Keefe admitted that he has paid for and used Winnemucca's alleged prostitution services and, as is evidenced in his affidavit, he believes that his disclosure of details will not implicate him but rather will bolster Rinehart's argument that Winnemucca should not be believed, a neat statement of the racial-sexual double standard. In this same telegram sent by Rinehart to the Office of Indian Affairs nine citizens signed a "Statement of Citizens regarding the Character of Sarah Winnemucca" in which they asserted, "Our long residence in close proximity to the Malheur Indian Agency has rendered us familiar with the character and habits of this woman; and we unhesitatingly say that it is provable by good and legal testimony that Sarah Winnemucca is, and for years has been a common prostitute, addicted to drunkenness. That it is well understood that by reason of her known and notorious lewd and lascivious habits she was some time

\footnotetext{
${ }^{79}$ Ibid.
} 
ago discharged by Major Rinehart from government employ." ${ }^{80}$ Here again the charge of prostitution, rather than her failure to do her job as interpreter, is the key evidence for proving that Winnemucca's words against Rinehart have no validity. No attempt is made by Rinehart in these letters to defend his actions as Indian agent of the Malheur reservation, nor does he attempt a rebuttal of what he thinks Winnemucca might be accusing him of in Washington. Rinehart capitalized solely on the widespread belief that most Indian women were morally loose and therefore his accusations against Winnemucca would not only go unquestioned but would provide ample evidence to discredit her statements - making a defense of his personal job performance unnecessary. As multiple men in positions of power capitalized on the Indian woman's hyper sexual identity to discredit Winnemucca, her public voice against these tropes became louder and louder.

\section{Boston: Winnemucca Responds to Sexual Slander}

Winnemucca's rebuttals to slanderous attacks from her political opponents are the most pronounced in her autobiography and will be addressed later in this section. First, it should be noted that when naming rape, Winnemucca's East Coast lecture voice differs strongly from her lecture voice in San Francisco. In San Francisco Winnemucca tentatively named the rape of Indian women as the catalyst for the Pyramid Lake War - a

\footnotetext{
${ }^{80}$ Ibid., 128. ("Statement of Citizens Regarding the Character of Sarah Winnemucca" dated January 14,1880 )
} 
war that took place between whites and Paiutes nearly nineteen years previously. Upon her arrival in Boston Winnemucca's voice for naming rape became bold. To one of her Boston audiences the Boston Evening Transcript reported Winnemucca to have lectured, "You know not what your agents and white men do in the far West;... how they insult the virtue of the Indian girls, and virtue is as precious a jewel among the Piutes as here in Boston. For these outrages the Indians take up arms, and never an Indian raid was made but what was brought about by such causes as these." 81 In this lecture Winnemucca not only identifies the Indian woman as victim but declares that innocent Indian girls are the victims of white male assault and that Indian men rightly and justifiably defend the honor of their women. Winnemucca then affirms to her audience that Indians would not raid white settlers if white men would stay away from their girls. Using her public voice Winnemucca demonstrated how the individual acts of whites raping Indian women became public wrongs committed against Indian communities and cause casualty and eventual war for whites.

Winnemucca's narrative is her strongest voice for re-identifying Indian women as objects of white male sexual aggression and victims of captivity and rape by white men. The reverberating theme of Indian women's sexuality can be found throughout Winnemucca's book. Winnemucca refutes the hyper sexuality of Indian women in her narrative on five counts. First, Winnemucca shows how the Indian woman is the victim of white male sexual desire. Winnemucca refutes the idea that Indian women invite

81 "Princess Winnemucca on the Treatment of the Indians," Boston Evening Transcript, May 3, 1883. (emphasis added) 
sexual encounters with white men by making it very clear that white men attack Indian women. Second, Winnemucca refutes the idea that Paiute women are sex slaves to their husbands by telling a tale of a deranged Indian man who sells his wife into prostitution, highlighting the abhorrence of the action and its exceptional, singular nature. Third, Winnemucca shows the tenacity with which Indian women defend their virtue by consistently emphasizing scenarios in which Indian women do not travel alone for fear of sexual victimization. Fourth, Winnemucca cites examples of Indian women who are about to be raped who defend their virtue with ferocity. And fifth, Winnemucca names the rape of Indian women as the cause that incites Paiutes to defensive, retaliative war.

The first detailed instance of rape Winnemucca recounts is in the first chapter of her narrative. Maximizing the discomfort of her readers it is the rape of her sister, who, as Zanjani noted was probably not more than thirteen or fourteen years old because Paiute girls often married soon after they became physically mature. ${ }^{82}$ By highlighting a young girl as the victim of rape Winnemucca erases any blame whites might be able to place on this girl as a result of their stereotyping of Indian women. Because the victim is an innocent girl she has not yet had a chance to become a self-seeking Indian woman trying to earn money, a prostitute, or a fully assimilated Indian "heathen" who invites sexual encounters. Winnemucca's grandfather had arranged for Winnemucca and her mother and sister, as well as some uncles and brothers to work for two wealthy ferry owners, a Mr. Scott and a Mr. Bonsal on the San Joaquin River. The girls and their

\footnotetext{
${ }^{82}$ Zanjani, Sarah Winnemucca, 34.
} 
mother were supposed to learn to work and cook while the Indian men helped these two wealthy men with their horses and cows. Winnemucca noted that the men were paid well for their work but that she and her sister and mother had a difficult time. She wrote, "The (white) men...would come into our camp and ask my mother to give our sister to them. They would come in at night and we would all scream and cry; but that would not stop them...My uncles and brothers would not dare to say a word, for fear they would be shot down." ${ }^{83}$ Eventually, Winnemucca and her mother and sister returned to their tribe where Winnemucca's sister, Mary, was put under the watchful care of her grandmother. Winnemucca wrote later in her narrative that, "The mothers are afraid to have more children, for fear they shall have daughters, who are not safe even in their mother's presence." 84 The raping of an Indian girl by white men in her mother's presence not only repositions the Indian female as the object of male aggression, but emphasizes the innocence of the Indian woman and the savagery of the white male.

In a passage meant to refute the stereotype that Paiute Indian women are sexual slaves for their husbands and that prostitution is an acceptable or integral part of Paiute Indian culture - Winnemucca reports a male member of her tribe who sells his wife into prostitution to white men for money. Here she is careful to say that the woman is not choosing prostitution and the Paiute man is the exception to the rule. Of this Indian named Dave she wrote,

\footnotetext{
${ }^{83}$ Hopkins, Life Among the Piutes, 34.

${ }^{84}$ Ibid., 48.
} 
I have known him many years, and have always been ashamed of him as a Piute. Twenty years ago I knew him to blow a young girl's brains out because she refused to marry him, and his behavior ever since has been in keeping with that. It is no secret among my people that he exposes his wife to bad white men for money. He is not a 'leading man.' No man can be a leading man among Indians unless he is honorable and brave. Dave is neither. On the contrary, he has no character whatever, and could always be hired to do a wicked thing. ${ }^{85}$

Far from the Paiute norm being that women were sexual slaves for their husbands, Dave's wife is the exception. First, when a Paiute girl refuses to marry Dave, he is a crazy lunatic who blows her brains out. Second, not only is Dave labeled a coward without honor but he has no chance whatsoever of gaining the respect of his people. In this passage Winnemucca refutes the stereotype of the Indian woman being the "squaw" who is coerced into prostitution by her husband by labeling this Paiute man a crazy lunatic. She also refutes the stereotype that Indian men selling their wives into prostitution is an accepted cultural practice among the Piutes by communicating that Dave is a man whom no one in her tribe will ever respect.

Winnemucca makes it very clear that white men attack Indian women - and thus combats the stereotype of the Indian woman who invites sexual encounters. One way Winnemucca does this is by having the Indian people in her narrative constantly make arrangements to protect Indian women from traveling alone so that they do not fall prey to white men. The narrative is rich with phrases like, "I am so glad, my people, to hear you say so, because I was going to leave my poor sister here all alone with the soldiers. I

\footnotetext{
${ }^{85}$ Ibid., 98.
} 
was afraid they might abuse her." 86 And speaking of traveling with her sister, Winnemucca wrote, "Lieutenant Wilkinson said he would go with us, for they could not let us go alone, as there were bad white men who might harm us..."87 By consistently recording cautiously orchestrated scenarios in which Indian women avoid traveling alone, Winnemucca combats the stereotype that Indian women were loose women looking for sexual encounters with white men.

In addition to narrating scenarios in which Indian women do not travel alone Winnemucca tells stories of white men attacking Indian women and the ferocity that Indian women demonstrate when defending their virtue. While Winnemucca and (a woman she calls her sister) Mattie are traveling across the frontier they pack knives for protection. During their journey, they found themselves in deep snowfall and stopped at a trusted friend of Winnemucca's, a Mr. Anderson's house, to wait out the storm. Finding that eight other traveling men had also done the same thing Winnemucca wrote,

I said to sister, "Oh how my heart jumps. Something is going to happen to us dear."

"I feel that way too," sister said. We sat a long time, but it was very cold, and at last we lay down and I soon fell asleep.

Some one laid a hand on me and said, "Sarah!"

I jumped up with fright and gave him such a blow right in the face. I said, "Go away, or I will cut you to pieces, you mean man!" He ran out of the house, and Mr. Anderson got up and lighted a candle. There was blood on the side of the bed, and on my hands and the floor.

\footnotetext{
${ }^{86}$ Ibid., 102.

${ }^{87}$ Ibid., 167.
} 
He said, "Oh, Sarah, what have you done? Did you cut him?"

"No, I did not cut him; I wish I had. I only struck him with my hand." 88

Winnemucca's immediate self-defense, as well as her claim that she and Mattie packed knives with them for the purpose of defending their virtue, "positions (Indian women) as subjects who act rather than objects who are acted upon." 89 Winnemucca further clarifies her position as a woman who acts to defend her virtue, when she asserts, "there is no living man that can do anything to a woman if she does not wish him to."90

Winnemucca's narrative not only reverses the hyper-sexual identities of Indian women but guides her reader to realize that the previously considered private wrongs of rape against individual Indian women are actually public wrongs of whites against all Indians because the act incites war. Winnemucca presents this message clearly in her narrative and devotes two of her eight chapters to the Indian/white wars ignited by the rape of Indian women by white men. Winnemucca's narrative parses out the details of the kidnapping and rape of the two Indian girls by whites as the catalyst for the Pyramid Lake War and makes no mention of possible scenarios that might've induced the Paiutes to fight The Bannock War's cause is credited with a similar scenario of rape by white men. A group of Bannock women were out digging roots when white men came upon

\footnotetext{
${ }^{88}$ Hopkins, Life Among the Piutes, 232. See Gregory Wright, "(Re)Writing the Captivity Narrative: Sarah Winnemucca's Life Among the Piutes Records White Male Sexual Violence," Nevada Historical Society Quarterly 51, no. 3 (Fall 2008): 209.

${ }^{89}$ Wright, "(Re)Writing the Captivity Narrative," 209.

${ }^{90}$ Hopkins, Life Among the Piutes, 228.
} 
them and seized one of them and, "used her shamefully."91 The other women got away, but two Bannock Indian men, one the brother of the raped girl, found and shot the two white rapists. As punishment for killing the two men, whites took the Bannock's ponies, and all their guns. The starving Bannock incited the similarly starving Paiute to war against the whites. ${ }^{92}$ In these stories not only are Indian women the victims of white rapists, Indian men nobly defend and avenge the virtue of their women to the point that they will all take up arms against whites if any member of their tribes' virtue is compromised. Winnemucca locates the beginning of each war with the rape of an Indian female and the retaliation of Indian males. She recounts the number of casualties on each side and the violence that ensues between the races because of the individual acts of violence white men commit against Indian women. Winnemucca remarked, "If the Indians were protected, as they call it, instead of the whites, there would be no Indian wars."93

\footnotetext{
${ }^{91}$ Ibid., 139.

${ }^{92}$ As Wright records, "The consequences of the Bannock War were extreme for the Northern Paiute: The government closed the Malheur Agency and, in the winter of 1879, forced the Northern Paiute to walk three hundred and fifty miles through deep snow to the Yakama Reservation. The cost in human life was great as five hundred and fifty Northern Paiutes died on a march that is reminiscent of the Cherokee Trail of Tears." Wright, "(Re)Writing the Captivity Narrative," 210.

${ }^{93}$ Hopkins, Life Among the Piutes, 178.
} 


\section{Conclusion}

Through her lectures and her narrative Winnemucca's public voice progressively combated the hyper-sexualized stereotypes of Indian women by re-identifying Indian women's morality, publicizing the rape of Indian women on the frontier and naming rape as a catalyst for war between Paiutes and whites. ${ }^{94}$ Winnemucca's public voice was based in the gendered rhetoric of womanhood, motherhood and morality, and over time makes it very clear that the rape of Indian women by white men was a frequent occurrence, resituating rape as a central theme of colonial relations in the settlement of the Americas. Despite her compelling message, Winnemucca struggled with disappointing results in the public sphere. In San Francisco she found mostly sympathetic but distant and uninterested audiences when it came to helping the Indian. In Washington Winnemucca unknowingly became the self-sacrificing Indian princess who helped to further the positive public relations of Secretary Schurz. She was used by Schurz and discredited among her own people. And in the East, Winnemucca could not escape the Indian woman's hyper-sexual identity placed upon her by male reformers, nor could she convince Christian female reformers that there was another way, aside from total Indian assimilation, for Paiutes and whites to coexist as citizens. Winnemucca's attempts to gain redress among Indian reformers in the East were, in the end, thwarted by

\footnotetext{
${ }^{94}$ Yet, in keeping with nineteenth century True Womanhood notions of sexual purity Winnemucca never definitively states that SHE was actually raped, or, that her virtue was taken from her. In his book White Into Red, Heard noted that, "most white women redeemed from captivity in the West charged that sexual abuse of their fellow captives was common but claimed that because of some unusual circumstance they, themselves, had been spared the ordeal." J. Norman Heard, White Into Red: Study of the Assimilation of White Persons Captured by Indians (Metuchen: Scarecrow Press, Inc., 1973), 101.
} 
the very reformers whose support she sought. At the root of her inability to achieve the rights she sought for her people lay a reform landscape dominated by whites unable to reconcile Winnemucca's vision of citizenship with their version of a Christianized, individualistic, civilian managed and white-taught Indian society. These fundamental differences lay at the heart of her opposition - an opposition that ultimately used "heathen" characterizations and hypersexual allegations to silence her public voice and discredit her character and by extension her arguments. 


\section{CONCLUSION}

Winnemucca returned from her trip to the East midsummer of 1884 . Her experience in the East was, no doubt, disappointing. She had not been able to gain the redress she was hoping for - her controversial reform agenda was rejected by Christianizing reformers. As Zanjani notes, however, Winnemucca was able to secure the release of the Yakama escapees - a win that must have given her at least some consolation. " Now the cheering crowds... and the days of summoning the eloquence of (Winnemucca) to speak for her people were behind her. She was going home to be once more the...schoolteacher she had been," concludes Zanjani. ${ }^{2}$ But this time, Winnemucca was going home to start her own school free from white oppression. Winnemucca returned to Lovelock, Nevada to live with her brother Natchez on his 160 acre ranch. ${ }^{3}$ She used the money she had raised on the East Coast from donations during her lectures and the proceeds from her book to start a school for Paiute children on Natchez's ranch. Additionally, she still had Elizabeth Peabody; a good friend, an ally, and an enthusiastic fundraiser on the East Coast who was ecstatic for Winnemucca to begin educating her people.

\footnotetext{
${ }^{1}$ Sally Zanjani, Sarah Winnemucca (Lincoln: University of Nebraska Press, 2001), 254.

${ }^{2}$ Ibid.

${ }^{3}$ The ranch was officially sold to Natchez in the spring of 1885 by railroad baron Stanford for $\$ 400$. Natchez had, however, been farming the land for years prior to Stanford selling it to him. "Naches a Land Owner," Carson Daily Index (Carson City, NV), May 9, 1885.
} 
Initially Winnemucca's school received much attention from the local press. The

Daily Alta California wrote,

We have referred already to the school for Indian children established in Nevada by the Piute woman, Princess Sarah Winnemucca. Her efforts have seemed to us to deserve encouragement. Travelers through Nevada who have seen the squalid crowds of Indian children...may think that the regeneration of those people is impossible. To change this opinion it is only necessary to consider the case of Sarah Winnemucca, who, when her childhood was long past, first had opportunities for education, and improved them so well that her attainments command the respect of all white people who know her. What education has done for her it may do for a majority of the children of that tribe in which she was born... She is very active for her people, and loses no opportunity to urge them forward in the path to civilization...

The Carson Daily Index ran an article lauding Winnemucca for her efforts. It read:

The efforts of Sarah Winnemucca to educate the children of her tribe by opening at school at Lovelock are commended by the press in and out of the State. The San Francisco Alta says, 'Out in Nevada is proceeding an experiment that deserves the respectful sympathy of the world. Princess Sarah...has opened a school for Indian children, and the young of her tribe are flocking to it for instruction.' 5

As this article points out, Winnemucca's school was deemed an "experiment." Indeed, this may have been the first known school run by an Indian in the United States.

Elizabeth Peabody detailed Winnemucca's "experimental" education plan in a pamphlet she wrote and published entitled, "Sarah Winnemucca's Practical Solution of the Indian Problem.” Peabody wrote, “...the very point I would make most prominent is that the

\footnotetext{
${ }_{5}^{4}$ Peabody, "Sarah Winnemucca's Practical Solution," 5.

5 "Sarah Winnemucca's School," Carson Daily Index (Carson City, NV), April 15 1886.
} 
whole thing is an Indian idea and an Indian plan; and the reason that she (Winnemucca) feels me to be her mainstay is that I do not bother her with my suggestions, but wait to see what it is her impulse to do, because I see that she knows, as I cannot, how the Indian mind is to be approached and set at work for that self-development which is the only real education." idea" and an "experiment" eventually lead to its downfall, as Indian self-determination had few enthusiasts among settlers in the West. Though Winnemucca's school certainly proved itself successful, as its novelty wore off so did its publicity. What little funding Peabody was able to secure for Winnemucca in Boston began to dwindle, and after the spring of 1887 Winnemucca's school funding becomes difficult to trace. ${ }^{7}$ Government funding of Indian schools, as well as charitable donations remained with pre-existing assimilationist schools such as Hampton and Carlisle. ${ }^{8}$ Winnemucca was probably able to keep the school open intermittently via private funding from Peabody's own savings account as well as her and Natchez's ability to self-sustain on their ranch through the spring of $1889 .^{9}$

At this point Winnemucca probably went to live with her widowed sister, Elma, at Henry's Lake, Idaho, and the two scraped out a living together. ${ }^{10}$ On August 1,1891 ,

\footnotetext{
${ }^{6}$ Elizabeth Palmer Peabody, "Sarah Winnemucca's Practical Solution of the Indian Problem," Facsimile of the first edition from Cambridge: J. Wilson and Son, 1886, in History of Women 3539-3553, Corvallis, OR: Oregon State University, 13.

${ }^{7}$ Zanjani, Sarah Winnemucca, 280.

${ }^{8}$ Ibid., 269.

${ }^{9}$ Ibid., 286.

${ }^{10}$ Ibid., 293.
} 
three months before her death, Winnemucca once again appealed to her "soldier-father" friend General O.O. Howard in desperation. She wrote,

My dear friend...I write to tell you how poorly I am getting along. I am staying here with my sister who is all alone like myself... We have both worked very hard this summer and have just made enough to live, that's all. We have not made enough to live on during the coming winter...Oh! My dear friend General, can you do some thing for me or say something in my behalf towards having the government do little something for me. Or start me in to something so I can make a living. I can see many things that I can go into to make a good living at. If I only had a little help from the government and make little money besides... You can intercede for me if you only will. And I know you can at least try. And I hope and pray you will try...

Whether or not General Howard attempted to help Winnemucca in her poverty remains unknown. Three months after Winnemucca wrote to Howard she died suddenly. On October 16, 1891, Winnemucca had just finished eating a meal at Elma's house that included Elma's homemade chokecherry wine. Winnemucca complained of severe stomach cramping and collapsed. The coroner who attended to Winnemucca's death reported the cause as, "too much chokecherry wine," a slight put-down similar to those she had known in life. ${ }^{12}$

Winnemucca's lasting legacy is her courageous willingness to tackle head-on the problematic realities of her time. As with many other figures in history of similar courage, Winnemucca's successes were overshadowed during her lifetime by a dominant

\footnotetext{
${ }^{11}$ Letter from Winnemucca to General O. O. Howard, August 1, 1891. Sarah Winnemucca Hopkins to General Oliver Otis Howard. Oliver Otis Howard Papers, 1833-1912. The George J. Mitchell Department of Special Collection and Archives, Bowdoin College Library.

${ }^{12}$ Zanjani, Sarah Winnemucca, 296.
} 
opposition unwilling to confront those problematic realities. She spoke truth in the face of opposition - of her life Winnemucca states, "I have been sincere with my own people when they have done wrong, as well as with my white brothers." In her honesty and candid appeals lay the strength of her message and the basis of her popularity on the lecture circuit. Not surprisingly, it is this same honesty that engendered deep opposition and ultimately undermined her cause. Winnemucca accurately observed:

Everyone knows what a woman must suffer who undertakes to act against bad men... Wherever I have been known, I have been believed and trusted... Those who have maligned me have not known me. It is true that my people sometimes distrust me, but that is because words have been put into my mouth which have turned out to be nothing but idle wind. Promises have been made to me in high places that have not been kept, and I have had to suffer for this in the loss of my people's confidence. ${ }^{13}$

Of her people Winnemucca wrote, “They are brave and will not be imposed upon. They are patient, but they know black is not white." The same is true of Winnemucca, and the statement exudes her valiant character. To date, Winnemucca has not received the same level of recognition and notoriety as Pocahontas or Sacagawea, whose legacies are founded in quiet assistance to whites. By contrast Winnemucca's voice of oppositional conformity demands a more complicated reckoning, more than "black" and "white." Indeed, her legacy has not yet been fully realized - maybe precisely because she has had a voice: pungent, critical, and astute.

\footnotetext{
${ }^{13}$ Sarah Winnemucca Hopkins, Life Among the Piutes: Their Wrongs and Claims (Reno: University of Nevada Press, 1994), 258.
} 


\title{
REFERENCES
}

\section{PRIMARY SOURCES}

\section{Manuscript Material}

Oliver Otis Howard Papers, 1833-1912. The George J. Mitchell Department of Special

Collection and Archives, Bowdoin College Library.

Special Files of the Office of Indian Affairs. "The Case of Sarah Winnemucca." M 574, Roll 74, File 268. National Archives, Washington, DC.

\section{Books and Journal Articles}

Hopkins, Sarah Winnemucca. Life Among the Piutes: Their Wrongs and Claims. Reno: University of Nevada Press, 1994.

Howard, Oliver Otis. Famous Indian Chiefs I Have Known. Lincoln: University of Nebraska Press, 1989.

. My Life and Experiences Among Our Hostile Indians. New York: De Capo Press, 1972.

Peabody, Elizabeth Palmer. "Sarah Winnemucca's Practical Solution of the Indian Problem." Facsimile of the first edition from Cambridge: J. Wilson and Son, 1886, in History of Women 3539-3553, Corvallis, OR: Oregon State University, Microfilm Reel 474.

Ronda, Bruce A. ed. Letters of Elizabeth Palmer Peabody. Middletown, CT: Wesleyan University Press, 1984.

Rowlandson, Mary. The Narrative of the Captivity and Restoration of Mrs. Mary Rowlandson. 1682. Reprinted in Narrative of the Indian Wars by Charles Lincoln. New York: Barnes \& Noble, Inc., 1966.

\author{
Newspapers \\ Atlanta Constitution \\ Bismarck Daily Tribune \\ Boston Daily Globe
}


Boston Evening Transcript

Bozeman Chronicle

Carson Daily Appeal

Carson Daily Index

Chafey News

Chloride Belt

Chicago Daily Tribune

Columbian

Daily Alta California

Daily Nevada Tribune

Daily News

Fitchburg Daily Sentinel

Freeborn County Standard

Gold Hill Daily News

Humboldt Registrar

Humboldt Star

Idaho Tri-Weekly Statesman

Lewiston Teller

Morning Appeal

Morning Oregonian

New York Times 
San Francisco Bulletin

Sunday Oregonian

Washington Post

\section{SECONDARY SOURCES}

\section{Books and Journal Articles}

Ackerman, Lillian. A Necessary Balance: Gender and Power Among Indians of the Columbia Plateau. Norman: University of Oklahoma Press, 2003.

Allen, Paula Gunn. The Sacred Hoop: Recovering the Feminine in American Indian Traditions. Boston: Beacon Press, 1992.

Allen, Paula Gunn. Pocahontas: Medicine Woman, Spy, Entrepreneur, Diplomat. San Francisco: Harper, 2003.

Bakken, Gordon Morris, and Brenda Farrington. The Gendered West: The American West. Routledge, 2001.

Barr, Juliana. Peace Came in the Form of a Woman: Indians and Spaniards in the Texas Borderlands. Chapel Hill: University of North Carolina Press, 2007.

Bataille, Gretchen M., and Kathleen Mullen Sands, eds. American Indian Women Telling Their Lives. Lincoln: University of Nebraska Press, 1984. , and Lisa Laurie, eds. Native American Women: A Bibliographical Dictionary. New York: Garland Publishing, 1993.

Bolt, Christine. American Indian Policy and American Reform: Case Studies of the Campaign to Assimilate the American Indians. London: Allen and Unwin, 1987.

Brimlow, George Francis. The Bannock Indian War or 1878. Caldwell: The Caxton Printers, Ltd., 1938.

_. "The Life of Sarah Winnemucca: The Formative Years.” Oregon Historical Quarterly 53, no. 2 (June 1952): 103-134.

Brown, Dee. Bury My Heart at Wounded Knee: An Indian History of the American West. New York: Henry Holt, 1970. 
Brown, Elsa Barkley. "To Catch the Vision of Freedom: Reconstructing Southern Black Women's Political History, 1865-1880," In Unequal Sisters: An Inclusive Reader in U.S. Women's History. $4^{\text {th }}$ ed. Edited by Vicki L. Ruiz with Ellen Carol DuBois. New York: Routledge, 2008.

Brumble, H. David. American Indian Autobiography. Berkeley: University of California Press, 1988.

Canfield, Gae Whitney. Sarah Winnemucca of the Northern Paiutes. Norman: University of Oklahoma Press, 1983.

Carpenter, Cari. Seeing Red: Anger, Sentimentality, and American Indians. Columbus: Ohio State University Press, 2008.

. “Tiresias Speaks: Sarah Winnemucca's Hybrid Selves and Genres.” Legacy 19, no. 1 (2002): 71-80.

Castañeda, Antonia. “Gender, Race, and Culture: Spanish-Mexican Women in the Historiography of Frontier California." Frontiers: A Journal of Women's Studies 11, no. 1 (1990): 8-20.

. "Introduction: Gender on the Borderlands." Frontiers: A Journal of Women's Studies 24, no. 2 (2003): 11-19.

. “Que se Pudieran Defender (So You Could Defend Yourselves)': Chicanas, Regional History, and National Discourses.” Frontiers: A Journal of Women's Studies 22, no. 3 (2001): 116-142.

. "Women of Color and the Rewriting of Western History: The Discourse, Politics, and Decolonization of History." Pacific Historical Review 61, no. 4 (November 1992): 501-533.

Castiglia, Christopher. Bound and Determined: Captivity, Culture-Crossing, and White Womanhood from Mary Rowlandson to Patty Hearst. Chicago: University of Chicago Press, 1996.

Clinton, Catherine, and Michele Gillespie, eds., "The Sexual Politics of Race and Gender: Mary Musgrove and the Georgia Trustees," In The Devil's Lane: Sex and Race in the Early South. New York: Oxford University Press, 1997.

Culley, Margo. American Women's Autobiography: Fea(s)ts of Memory. Madison: University of Wisconsin Press, 1992. 
Dippie, Brian W. The Vanishing American: White Attitudes and U.S. Indian Policy. Middletown, CT: Wesleyan University Press, 1982.

Dudden, Faye E. Fighting Chance: The Struggle over Woman Suffrage and Black Suffrage in Reconstruction America. New York: Oxford University Press, 2011.

Frizzell, George E. "Politics of Cherokee Citizenship, 1898-1930." North Carolina Historical Review 61, no. 2 (April 1984): 205-230.

Gilbert, Deborah. "Sarah Winnemucca Hopkins: Performer, Activist, and Educator Teaching Western History in the First Person." Journal of the West 43, no. 4 (2004): 24-31.

Ginzberg, Lori D. Women and the Work of Benevolence: Morality, Politics, and Class in the Nineteenth-Century United States. New Haven: Yale University Press, 1990.

Gohdes, Clarence L. F. The Periodicals of American Transcendentalism. Durham, NC: Duke University Press, 1931.

Green, Rayna. "The Pocahontas Perplex: The Image of Indian Women in American Culture." Massachusetts Review 16, no. 4 (Autumn 1975): 698-714.

Grossberg, Michael. "Bringing the History of American Family Law into the Classroom." OAH Magazine of History 15, no. 4 (Summer 2001): 23-27.

Gura, Philip F. American Transcendentalism: A History. New York: Hill and Wang, 2007.

Haberly, David. "Women and Indians: The Last of the Mohicans and the Captivity Tradition.” American Quarterly 28, no. 4 (Autumn 1976): 431-444.

Heard, J. Norman. White Into Red: Study of the Assimilation of White Persons Captured by Indians. Metuchen: Scarecrow Press, Inc., 1973.

Hoxie, Frederick E., Ronald Hoffman, and Peter J. Albert, eds. Native Americans and the Early Republic. Charlottesville: University Press of Virginia, 1999.

Jackson, Helen Hunt. A Century of Dishonor. Minneapolis: Ross and Haines, 1964. First published 1881 by Harpers and Brothers, New York. Page references are to the 1964 edition. 
Jacobs, Margaret. "Getting Out of a Rut: Decolonizing Western Women's History." Pacific Historical Review 79, no. 4 (November 2010): 585-604.

Janiewski, Dolores. 'Giving Women a Future: Alice Fletcher, the 'Woman Question,' and 'Indian Reform,"' In Visible Women: New Essays on American Activism. Edited by Nancy A. Hewitt and Suzanne Lebsock. Urbana, Il: University of Illinois Press, 1993.

Kennedy, Randall. Interracial Intimacies: Sex, Marriage, Identity, and Adoption. New York: Pantheon Books, 2003.

Kidwell, Clara Sue. "Indian Women as Cultural Mediators." Ethnohistory 39, no. 2 (Spring 1992): 97-107.

Kilcup, Karen, ed. Native American Women's Writing. 1800-1924: An Anthology. Oxford: Blackwell Publishers, 2000.

Klein, Laura F., and Lillian A. Ackerman, eds. Women and Power in Native North America. Norman: University of Oklahoma Press, 1995.

Knack, Martha C., and Omer C. Stewart. As Long as the River Shall Run: An Ethnohistory of Pyramid Lake Indian Reservation. Berkeley: University of California Press, 1984.

. Boundaries Between: The Southern Paiutes, 1775-1995. Lincoln: University of Nebraska Press, 2001.

Lape, Noreen Groover. "II Would Rather Be with My People, but Not to Live with Them as They Live': Cultural Liminality and Double Consciousness in Sarah Winnemucca Hopkins's Life Among the Piutes: Their Wrongs and Claims." American Indian Quarterly 22, no. 3 (Summer 1998): 259-279.

Larré, Lionel. "War of Signs, War of Words, War of Worlds: Sarah Winnemucca Hopkins' Life Among the Piutes." European Contributions to American Studies 54 (January 2005): 109-118.

Lawrence, Bonita. "Gender, Race, and the Regulation of Native Identity in Canada and the United States: An Overview." Hypatia 18, no. 2 (Spring 2003): 3-31.

Lewis, David. "Reservation Leadership and the Progressive-Traditional Dichotomy," in American Nations: Encounters in Indian Country, 1850 to the Present. Edited by Frederick E. Hoxie, Peter C. Mancall, and James H. Merrell. New York: Routledge, 2001. 
Lukens, Margo. "Her 'Wrongs and Claims': Sarah Winnemucca's Strategic Narratives of Abuse." Wicazo Sa Review 13, no. 1 (1998): 93-108.

Mathes, V.S. "Nineteenth Century Women and Reform: The Women's National Indian Association." American Indian Quarterly 14, no. 1 (Winter 1990): 1-18.

Morin, Karen. "British Women Travellers and Constructions of Racial Differences across the Nineteenth-Century American West." Transactions of the Institute of British Geographers, New Series 23, no. 3 (1998): 311-330.

Movius, James Gilbert. "White-Paiute Conflicts." The Journal of the Shaw Historical Library 6 (1992): 33-54.

Namias, June. White Captives: Gender and Ethnicity on the American Frontier. Chapel Hill: University of North Carolina Press, 1993.

Newman, Louise. White Women's Rights: The Racial Origins of Feminism in the U.S. New York: Oxford University Press, 1999.

O'Connell, Shaun. Imagining Boston: A Literary Landscape. Boston: Beacon Press, 1990.

Osburn, Katherine M. B. “'Dear Friend and Ex-Husband"”: Marriage, Divorce, and Women's Property Rights on the Southern Ute Reservation, 1887-1930," in Negotiators of Change. Edited by Nancy Shoemaker. New York: Routledge, 1995.

Painter, Nell Irvin. "Representing Truth: Sojourner Truth's Knowing and Becoming Known.” Journal of American History 81, no. 2 (September 1994): 461-492.

Pedersen, Elaine. "Deciphering the Ormsby Gown: What Does It Tell?" Nevada Historical Quarterly, no. 38 (1995): 75-88.

Perdue, Theda. "Native Women in the Early Republic: Old World Perceptions, New World Realities," in Native Americans and the Early Republic. Edited by Frederick E. Hoxie, Ronald Hoffman and Peter J. Albert. Charlottesville: University Press of Virginia, 1999. . Sifters: Native American Women's Lives. New York: Oxford University Press, 2001. 
Prucha, Francis Paul. The Great Father: The United States Government and the American Indians. 2 vols. Lincoln: University of Nebraska Press, 1984. . American Indian Policy in Crisis: Christian Reformers and the Indian, 18651900. Norman: University of Oklahoma Press, 1964.

Raibmon, Paige. Authentic Indians: Episodes of Encounter from the Late-NineteenthCentury Northwest Coast. Durham, NC: Duke University Press, 2005.

Rockwell, Stephen J. Indian Affairs and the Administrative State in the Nineteenth Century. New York: Cambridge University Press, 2010.

Ruoff, A. LaVonne Brown, and Jerry W. Ward. Redefining American Literary History. New York: The Modern Language Association of America, 1990.

Ryan, Mary. “A Women's Awakening: Evangelical Religion and the Families of Utica, New York, 1800-1840." American Quarterly 30, no. 5 (Winter 1978): 602-623.

Sale, Maggie Montesinos. “Reconceptualizing America.” Legacy 15, no. 1 (1998): 29-34.

Sands, Kathleen. American Women's Autobiography. Edited by Margo Culley. Madison: University of Wisconsin Press, 1992.

Saunt, Claudio. "The Paradox of Freedom: Tribal Sovereignty and Emancipation during Reconstruction of Indian Territory." Journal of Southern History 52, No. 1 (January 2004): 63-94.

Schechter, Patricia A. “'All the Intensity of My Nature': Ida B. Wells, Anger, and Politics." Radical History Review, no. 70 (1998): 48-77.

. Ida B. Wells-Barnett and American Reform, 1880-1930. Chapel Hill: University of North Carolina Press, 2001.

Scott, Lalla. Karnee: A Paiute Narrative. Reno: University of Nevada Press, 1966.

Senier, Siobhan. Voices of American Indian Assimilation and Resistance: Helen Hunt Jackson, Sarah Winnemucca, and Victoria Howard. Norman: University of Oklahoma Press, 2001.

Shoemaker, Nancy, ed. Negotiators of Change: Historical Perspectives on Native American Women. New York: Routledge, 1995. 
Smith, Andrea. Conquest: Sexual Violence and American Indian Genocide. Cambridge, MA: South End Press, 2005.

Smithers, Gregory. "The 'Pursuits of the Civilized Man': Race and the Meaning of Civilization in the United States and Australia, 1790s-1850s." Journal of World History 20, no. 2 (2009): 245-272.

Sneider, Allison L. Suffragists in an Imperial Age: US Expansion and the Woman Question 1870-1929. New York: Oxford University Press, 2008.

Sorisio, Carolyn. "Playing the Indian Princess? Sarah Winnemucca's Newspaper Career and Performance of American Indian Identities." Studies in American Indian Literatures 23, no. 1 (May 14, 2011): 1-37.

Steward, Julian H., and Erminie Wheeler-Voegelin. Paiute Indians: The Northern Paiute Indians. vol. 3. New York: Garland Publishing, 1974.

Swann, Brian, and Arnold Krupat, eds. I Tell You Now: Autobiographical Essays by Native Writers. Lincoln: University of Nebraska Press, 1987.

Tharp, Louise Hall. The Peabody Sisters of Salem. Boston: Little, Brown, and Company, 1950.

Tong, Benson. Susan La Flesche Picotte, M.D.: Omaha Indian Leader and Reformer. Norman: University of Oklahoma Press, 1999.

Turner, Katharine C. Red Men Calling on the Great White Father. Norman: University of Oklahoma Press, 1951.

Waggoner, Linda M., "Adopting the Habits of Civilization: The Ho-Chunk Women Who Chose American Citizenship in 1870," (unpublished paper in author's possession cited with permission, 2012).

Welsh, Sandy, Jacquie Carr, Barbara MacQuarrie, and Audrey Huntly. “'I'm Not Thinking of It as Sexual Harassment': Understanding Harassment across Race and Citizenship." Gender and Society 20, no. 1 (February 2006): 87-107.

Welter, Barbara. "Cult of True Womanhood: 1820-1860.” American Quarterly 18, no. 2 (Summer 1966): 151-174.

West, Elliot. "Reconstructing Race.” Western Historical Quarterly 34, no. 1 (Spring 2003): 6-26. 
Williams, Carol J. Framing the West: Race, Gender, and the Photographic Frontier in the Pacific Northwest. New York: Oxford University Press, 2003.

Wolfe, Patrick. "Land, Labor, and Difference: Elementary Structures of Race." American Historical Review 106, no. 3 (June 2001): 866-905.

Womack, Craig S. Red on Red: Native American Literary Separatism. Minneapolis: University of Minneapolis Press, 1999.

Wright, Gregory. “(Re)Writing the Captivity Narrative: Sarah Winnemucca's Life Among the Piutes Records White Male Sexual Violence." Nevada Historical Society Quarterly 51, no. 3 (Fall 2008): 200-218.

Wright, Mary C. "The Woman's Lodge: Constructing Gender on the Nineteenth-Century Pacific Northwest Plateau." Frontiers: A Journal of Women Studies 24, no. 1 (June 10, 2003): 1-18.

Zanjani, Sally. Sarah Winnemucca. Lincoln: University of Nebraska Press, 2001.

\section{Websites}

Nevada State Library and Archives. "Sarah Winnemucca, An Annotated Bibliography," compiled and annotated by Mona Reno, last modified November 14, 2008, http://nsla.nevadaculture.org/dmdocuments/SarahWinnemucca_bibliography2008 .pdf. 